\title{
Calcretes in the Thar desert: Genesis, chronology and palaeoenvironment
}

\author{
R P DhiR ${ }^{1}$, S K TANDON ${ }^{2}$, B K SAREen ${ }^{1}$, R RAmesh ${ }^{3}$, T K G RAO R A J KAilath $^{3}$ and \\ N SHARMA ${ }^{2}$ \\ ${ }^{1}$ Central Arid Zone Research Institute, Jodhpur 342003, India. \\ ${ }^{2}$ Geology Department, University of Delhi, Delhi 110 007, India. \\ ${ }^{3}$ Physical Research Laboratory, Ahmedabad 380 009, India. \\ ${ }^{4}$ RSIC, Indian Institute of Technology, Powai, Mumbai 400076 , India.
}

The calcretes in the Thar desert occur in a variety of settings, including the piedmonts, sheetwash aggraded plains; and this study adds calcretes in regolith and colluvio-alluvial plains to the group of settings in which calcretes occur in the region. Field logs, morphological details and analytical data such as petrographic, cathodoluminescence and geochemical characteristics are described along with a discussion on their implications. Sand dunes and sandy plains dating to $<20$ ka have weakly developed calcretes. The better-developed calcrete horizons occur in piedmonts, interdunes or in areas that have sufficient groundwater. Deep sections in the region show phases of calcrete development in aeolian sand aggradation at $\sim 150, \sim 100, \sim 60$ and $27-14$ ka. The extensive sheetwash plains have mature calcretes and date to mid-Pleistocene. Our studies indicate that these calcretes represent a hybrid process, where carbonate enrichment of the originally calcareous host occurred due to periodically raised groundwaters, and its differentiation into nodules occurred under subaerial environment i.e., after recession of groundwater. Deep sections also show a stack of discrete calcretes that developed in individual aggradation episodes with hiatuses as indicated by ESR dating results. Nodules display a multiplicity of carbonate precipitation events and internal reorganization of calcitic groundmass. The process is accompanied by degradation and transformation of unstable minerals, particularly clays and with a neosynthesis of palygorskite.

The ancient calcretes are dated from the beginning of the Quaternary to $\sim 600$ ka and show more evolved morphologies marked by brecciation, dissolution, laminar growth on brecciated surfaces, pisolites and several generations of re-cementation. Mica/chlorite schists and such other rocks are particularly vulnerable to replacement by carbonate. In an extreme case, replacement of quartzose sandstone was observed also. The presence of stretches of alluvio-colluvial plains in an area presently devoid of drainage bespeaks of occasional high-energy fluvial regime, under a semi-arid climate. The mid-Pleistocene period saw a shift towards more arid climate and this facilitated sheetwash aggradation. Finally, during the late Pleistocene, aggradation of aeolian sands indicated a progressively drier climate. However, this does not find its reflection in stable isotope data. The amount of carbonate in the form of calcretes is substantial. The present studies indicate that aeolian dust or rainwater are minor contributors to the carbonate budget. A more important source was provided by the pre-existing calcretes in the sheetwash aggraded plains and detrital carbonate in the aeolian sediments. The original source of carbonate in the region, however, remains unresolved and will need further investigations. Electron spin resonance protocols for the dating of calcretes were developed as a part of this study and the results accorded well with geological reasoning.

Keywords. Calcretes; Thar desert; Quaternary stratigraphy; ESR dating. 


\section{Introduction}

Calcretes are generally defined as terrestrial, near surface, secondary calcium carbonate accumulations in soil profiles, bedrocks, and sediments. The carbonate is introduced by replacive, displacive and/or passive mechanisms of precipitation (Goudie 1983; Wright and Tucker 1991). According to Yaalon (1988) soils with secondary carbonate accumulations cover an estimated $\sim 20$ million $\mathrm{km}^{2}$ or $13 \%$ of the land surface. As a distinctive pedogenic/geologic formation, calcretes have been intensively investigated for the past several decades for their typology, morpho-genetic features, petrology, chemistry, profile development and growth stages. Detailed reviews by Reeves (1976); Goudie (1983); Wright and Tucker (1991); Milnes (1992) and Tandon and Kumar (1999) provide a perspective on various studies on calcretes.

Abundance of calcretes in the Thar desert is a striking feature of the landscape. Natural resource surveys by Central Arid Zone Research Institute indicated extensive occurrence of calcrete as a subsoil feature or as outcrops under a thin aeolian mantle (e.g., Dhir and Kolarkar 1977). At several locations, the solum over the calcretes was too thin vis-à-vis calcrete development. This led Dhir et al (1982) to suggest that their origin could not be purely by pedogenic processes. Courty et al (1987) and later Achyuthan and Rajaguru (1998) brought out the complexity of carbonate nodules of calcretes of the aggraded plains, and inferred a polyphase mechanism for nodule formation. Sundaram et al (1996) reported thick reddish calcretes over mica schists in Sambhar area and speculated that these represent the oldest Quaternary formation. Das Sarma (1984) also suggested that calcrete duricrusts possibly formed the base of the Quaternary and post-date the ferricretes, the fragments of which are found embedded in these. Courty and Fedoroff (1985) studied recent and buried soils in the northern part of Rajasthan and adjoining Haryana. They recognized the early role of faunal activity in the preferential development of calcitic features, and suggested that a calcic horizon could develop very quickly in highly calcareous parent material. Dhir (1995), following Netterberg (1969), presented a morphology-based typology of calcretes and discussed their spatial distribution. Importantly, he recognized:

- the existence of ancient calcretes, which often occur associated with relict geomorphic surfaces and

- in situ nature of commonly found nodular calcretes.
Despite these investigations, several aspects of calcretes in the Thar have been poorly understood. Based on an exhaustive field mapping of the area, and detailed studies of sections, this paper presents a multi-dimensional analysis of Thar calcretes comprising results on host materials of calcrete occurrences, profile logs, genetic types, isotopic and elemental geochemistry, chronology, and environments of calcrete formation.

\section{Geological setting}

The main study area covering about sixty thousand square kilometers lies in the central part of Rajasthan arid zone (figure 1), and is characterized by a low and erratic rainfall, abundant sunshine, sparseness of vegetation cover and a strong wind regime. The mean annual rainfall ranges between $450 \mathrm{~mm}$ in the east and $250 \mathrm{~mm}$ in the west as against a potential evapotranspiration of 1550 and $1900 \mathrm{~mm}$. Nearly ninety per cent of the rainfall is confined to monsoon months, mostly in the form of a few rainfall events; some of which are able to saturate soil profile and even provide deep percolation. The region has a hot subtropical temperature regime, with mean maximum and minimum temperatures of the hottest month being $41.0^{\circ} \mathrm{C}$ and $26.3^{\circ} \mathrm{C}$ and that of the coolest month being $24.8^{\circ} \mathrm{C}$ and $10.2^{\circ} \mathrm{C}$ (Jodhpur). The soil temperatures at $60 \mathrm{~cm}$ depth are around $34^{\circ} \mathrm{C}$ in the hottest month and $24^{\circ} \mathrm{C}$ in the coolest month.

Proterozoic rocks mainly belonging to Marwar Supergroup are the most extensive formations in the region and comprise:

- the Jodhpur Group (sandstone, arkosic, occasionally pebbly and gritty, with shale and dolomitic limestone bands),

- the Bilara Group (limestone and dolomite), and

- the Nagaur Group (sandstone, siltstone, gypsum and clay).

The southern part consists largely of rhyolites whereas the eastern part is occupied by the Delhi Supergroup (biotite gneiss, quartz-mica schist, marble and limestone, arkosic grit with conglomerate). The southwestern part has a limited extent of Permo-Carboniferous Bap Boulder Beds and Lathi formation (sandstone, siltstone and pebbly sandstone) belonging to the Jurassic, and other younger rock suites. Presently, most of these rocks lie buried under alluvium and sands; their outcrops in the form of hills and pediments constitute $\sim 3-5 \%$ only. 


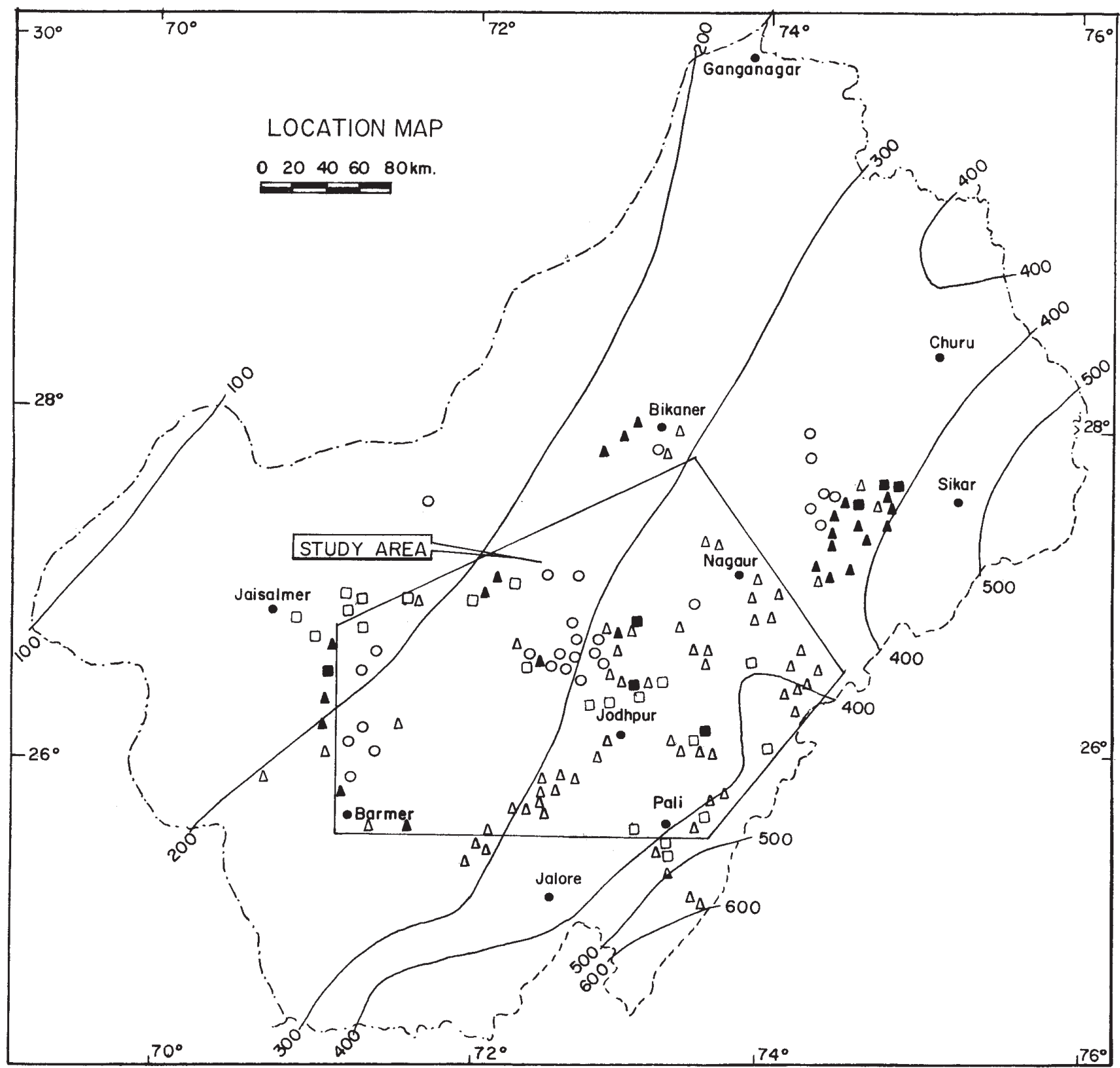

Figure 1. Map of arid zone of Rajasthan and the rainfall isohyets in millimeters. Inside polygon demarcates the main study area. Also shown are the examined sites in relation to host material of calcretes: aeolian-O; sheetwash aggraded plains- $\triangle$; regolith- $\square$; ancient in colluvio-alluvial plains- $\mathbf{\Delta}$; ancient in regolith-

Aravalli mountains are a prominent topographic feature along the eastern border of the study area but localised occurrences of residual hills, rocky and buried pediments are observed throughout the study area. A dominant landform is the older alluvial plains, that have been regarded well within the Quaternary in geological literature. Besides the Luni Basin, these alluvial plains extend to regions where no drainage system exists at present (figure 2). These plains are either exposed or lie buried under a mantle of aeolian sands. The soils here have well-developed zonal characteristics. Besides a pronounced cambic horizon, the soils generally host well-formed calcretes. Within these, remnants of old alluvial surfaces occur as mounds, a few meters above the surrounding plains. The southwestern part has a considerable extent of aeolian sediments in the form of hummocky plains and dunes. The dunes show a very weak and limited vertical redistribution of carbonate and incipient transformation of weatherable minerals, and thus are devoid of well-formed calcretes. The sandy 


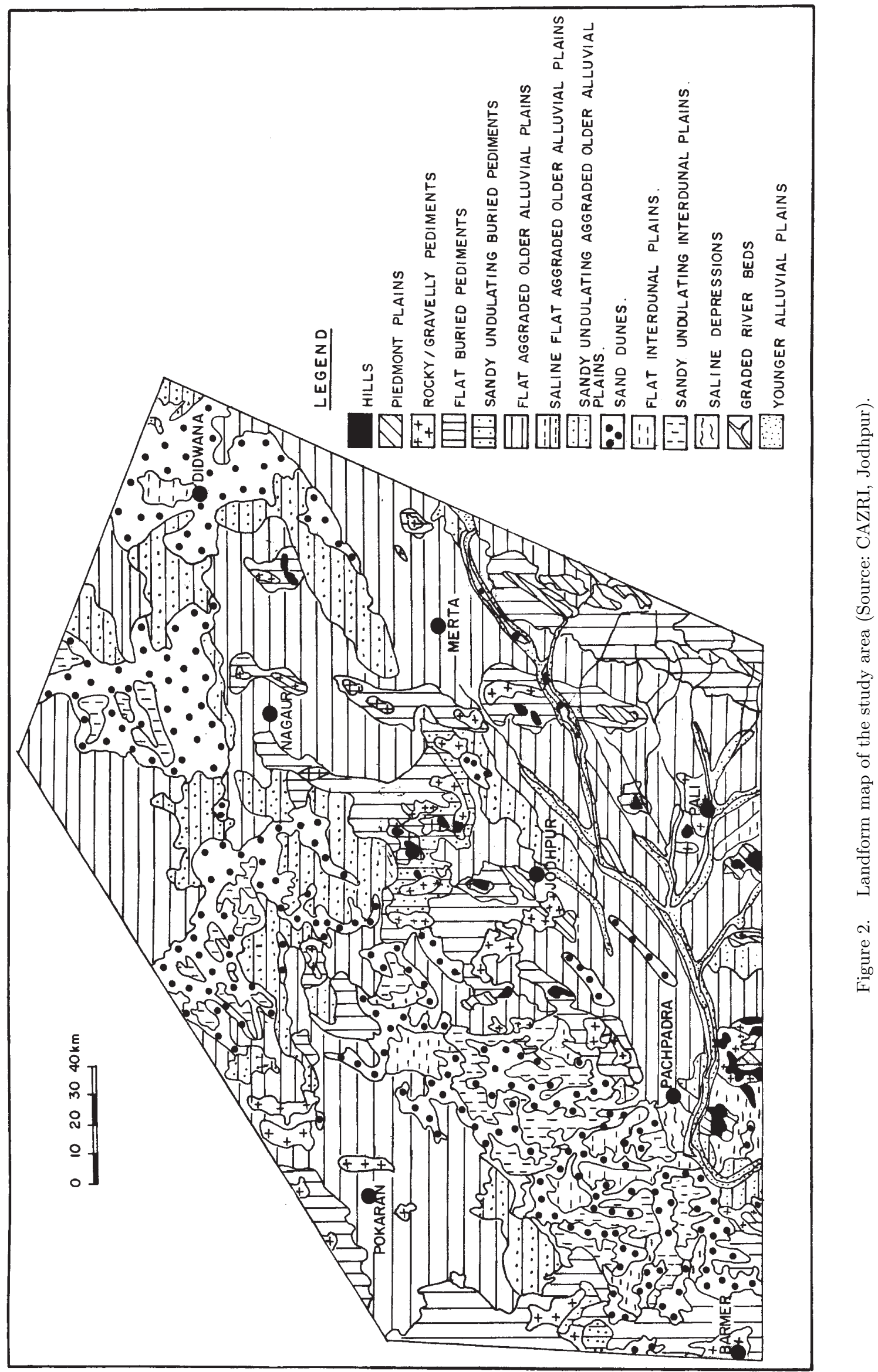


plains show a calcic horizon and localized patches with strongly developed calcretes.

Several vegetation types have been identified in the study area. The region bounded by $300-$ $450 \mathrm{~mm}$ annual rainfall zone and with loamy soils is characterized as mixed xeromorphic woodland with 20 to 40 trees/ha made up mostly of Prosopis cineraria. Zizyphus nummularia and Capparis decidua are the common shrubs. Besides, several perennial grass species are also present. The vegetation on aeolian landforms is grouped under psammophytic scrub desert. Here in the 250$450 \mathrm{~mm}$ rainfall zone there are trees and also a variety of shrubs and grasses. In the drier regions $(<250 \mathrm{~mm}$ annual rainfall), large sized shrubs and grasses constitute almost the sole cover. However, even under optimum conditions, the vegetation cover is $\leq 20 \%$. The shrubs have root system up to 5 meters whereas grasses have it up to 2 meters depth.

\section{Calcrete: Occurrences, materials and methods}

\subsection{Calcrete occurrences and host materials}

In the study area, calcretes occur in a variety of host materials and landforms. The aeolian sands in the form of dunes and plains constitute a dominant surficial cover. These sediments are moderately well sorted, the sorting coefficient being 0.6 to $0.7 \phi$ for dunes and 0.75 to $0.9 \phi$ for the plains. Fine sand $(0.1$ to $0.2 \mathrm{~mm})$ is the dominant fraction and the amount each of clay and silt varies from $3-$ $5 \%$ in dunes and $8-10 \%$ in the sandy plains respectively. The sediments are only slightly calcareous (average 2-4\%). The dunes possess very weak, powdery calcretes with occasional chalky nodules. Calcretes in the associated accumulative interdunes are better developed, but nodules are chalky only. In general, the sandy plains also have fairly well formed calcretes. In the vicinity of sandstone, rhyolite hills and large outcrops, the piedmonts show thick and chalky to hard nodular calcretes, similar to that formed on fluvially reworked aeolian sands. Besides, there are calcretes developed in patchy aeolian deposits on top of rock outcrops and flattopped hills.

Nearly flat alluvial plains with occasional rock outcrops and pediments are another widespread landform (figure 2). These are either exposed or are under a thin cover of aeolian sands. This landform occurs in the Luni River Basin, in the central Thar (with no organized drainage system) and in the more arid tract of Jaisalmer and Barmer (figure 2). This landform has been designated (Ghose et al 1977; Kar 1992) as a flat, aggraded older alluvial plain or as sandy undulating aggraded older alluvial plain. Our observations indicated that the alluvial aggradation is generally $\sim 2-10$ meters thick. Importantly, the sediments often contained clasts of local rocks and pre-existing calcretes, suggesting that these were transported, albeit for short distances. The particle size distribution indicated more clay and silt than in the aeolian sediments. The sand fraction had greater proportions of medium and coarse sized grains. In general, the sediments are poorly sorted as compared to the aeolian sands. Analogous to the aeolian sands, the fine sand fraction is dominated by quartz with up to $10-15 \%$ orthoclase and minor amounts of plagioclase and heavy minerals. The aggradation in these plains is inferred to have taken place through sheet flow and small sized, shifting channels. We have re-designated this landform as sheetwash aggraded plains. The sediments are mildly to fairly calcareous and host well-developed calcretes that comprise hard nodules. Within these plains are seen local occurrences, comprising alluvial aggradation also, that lie a few meters above the level of the surrounding plains. Some of these patches have a large proportion of boulders and gravels. These have well formed calcretes, often with evolved morphologies. But the calcrete profiles are often truncated or dismantled. We have regarded these as remnants of an ancient alluvial aggradation. In addition, calcretes in the regolith of bedrocks, some of which have great antiquity and an evolved morphology were also observed.

\subsection{Approach and methods of analysis}

In the present investigations, nearly 140 quarries/exposures were examined. These were described in relation to geomorphic setting, host sediments, and morphological expression. The selected sections were systematically logged and sampled. The location of the sections is shown in figure 3. Bulk samples of the identified lithounits and sub-units were collected. Wherever the calcretes occurred as an indurated mass, undisturbed samples were taken. Sub-sample of the bulk was passed through a sieve to collect $<2 \mathrm{~mm}$ internodular sediment for further analysis. The particle size analysis was performed after removal of carbonate by soil hydrometer and sieving. The carbonate estimation both in the nodules and the inter-nodular material was done volumetrically using Collin's calcimeter.

Standard thin sections were prepared following usual procedure. Cathodoluminescence (CL) studies were carried out in Tehnosyn chamber under vacuum at the Geology Department, University of Delhi and electron microprobe analysis (EPMA) 


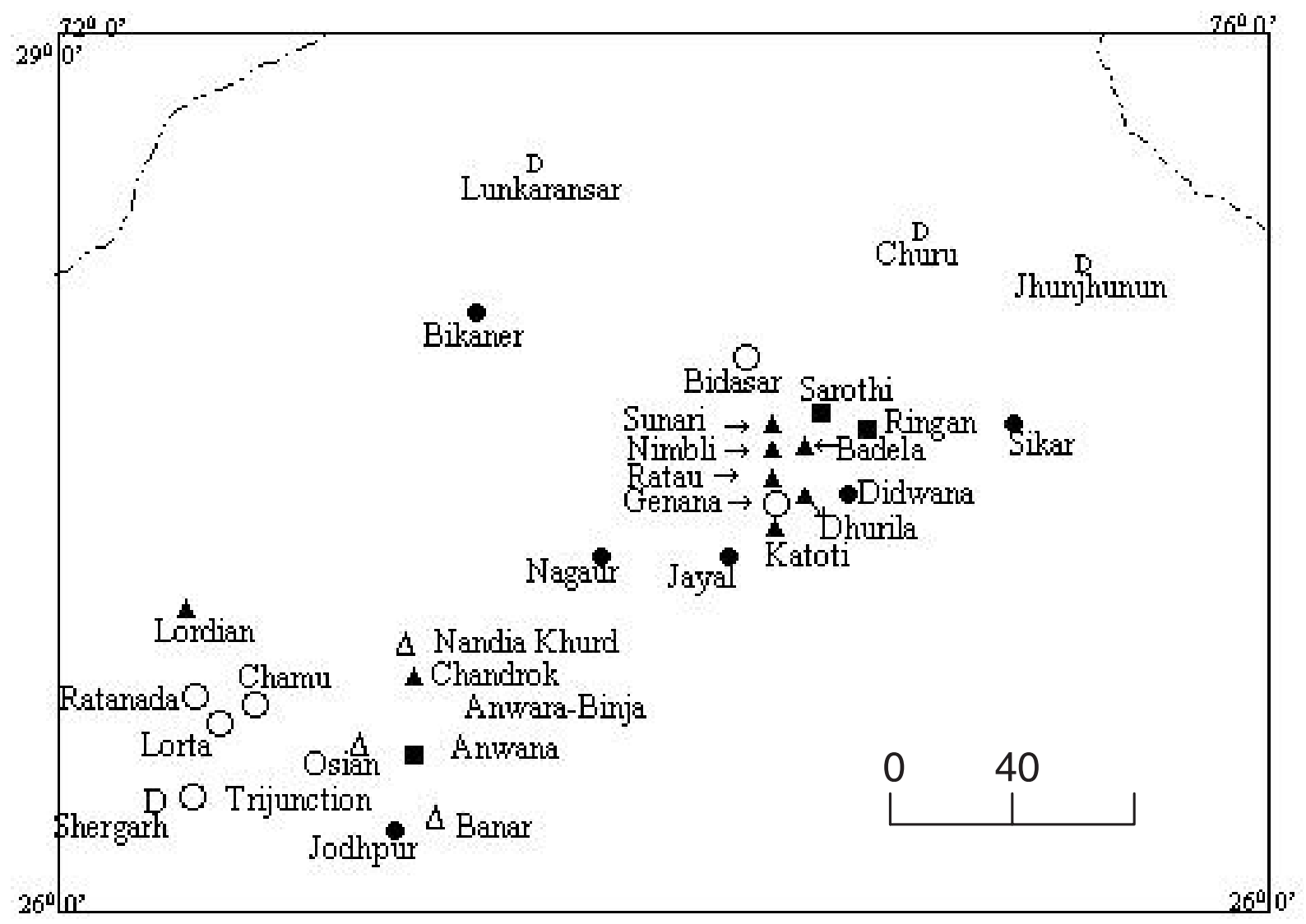

Figure 3. Location of the calcrete sites in relation to host: aeolian - O; sheetwash - $\Delta$; ancient calcretes in alluvium - $\Delta$; in regolith- $\mathbf{\square}$. 'D' marks location of sites sampled for dune profiles. A few sites lie outside the figure.

using CAMECA probe, at the Geological Survey of India's EPMA facility at Faridabad. For clay mineralogy, procedures described by Eitel and Stengele (1996) were used and the samples were disintegrated in $0.2 \mathrm{M}$ EDTA at $\mathrm{pH} 10-11$ to avoid the possibility of loss of clay in an acid solution. Sub-samples of the clay fraction were variously treated for mineral identification. In the Xray diffraction analysis, standard procedures were followed. In particular, palygorskite was identified by the appearance of a sharp peak at $10.4^{\circ} \mathrm{A}$ in Ca-saturated, glycolated samples that persisted up to $300^{\circ} \mathrm{C}$ and disappeared at $550^{\circ} \mathrm{C}$.

Most of the stable isotope analysis was performed at the Physical Research Laboratory on petrologically/optically-constrained features within a nodule or hardpan. Some measurements were made at the National Geophysical Research Institute, Hyderabad. In general, the samples were taken with a dentists' drill and reacted with pure phosphoric acid. About $1 \mathrm{mg}$ of dry carbonate powder $(\sim 120 \mu \mathrm{m})$ was reacted in an on-line extraction system with $100 \% \mathrm{H}_{3} \mathrm{PO}_{4}$ in vacuum $\left(10^{-3}\right.$ Torr $)$ at $70^{\circ} \mathrm{C}$. The evolved $\mathrm{CO}_{2}$ was purified of water vapor by passing through a U-tube surrounded by alcohol slurry kept at $-100^{\circ} \mathrm{C}$, and transferred to a GEO 20-20 mass spectrometer (PDZ, U.K.). The carbon $\left(\delta^{13} \mathrm{C}\right)$ and oxygen $\left(\delta^{18} \mathrm{O}\right)$ isotope ratios of the carbonate sample were calculated after correcting for isobaric interferences (Craig correction) for the measured $\delta^{45}$ and $\delta^{46}$ deviations from the laboratory gas standard, which was prepared from a large volume of foraminiferal calcite from the Arabian Sea with isotope ratios within $1 \%$ of the international PDB standard. The $\delta^{13} \mathrm{C}$ and $\delta^{18} \mathrm{O}$ values are reported here relative to the PDB standard, which was achieved by repeated measurement of the NBS-19 carbonate standard following the same procedure. All measurements were made at a major ion current (mass 44) of 10nA, and the sample and reference pressures were adjusted using bellows such that the major ion currents were in agreement within $1 \%$. More details of the procedure can be found in Yadava and Ramesh (1999). The standard uncertainty of the entire procedure both for $\delta^{13} \mathrm{C}$ and $\delta^{18} \mathrm{O}$ was $\pm 0.1 \%$.

Optical dating of sands that hosted some of the younger calcretes was carried out at the Physical Research Laboratory, Ahmedabad. As the optical dating has limitations of range; the electron spin resonance (ESR) dating method was attempted for calcretes associated with older geomorphic units. The use of this method involved several procedural innovations, details of which are given in 


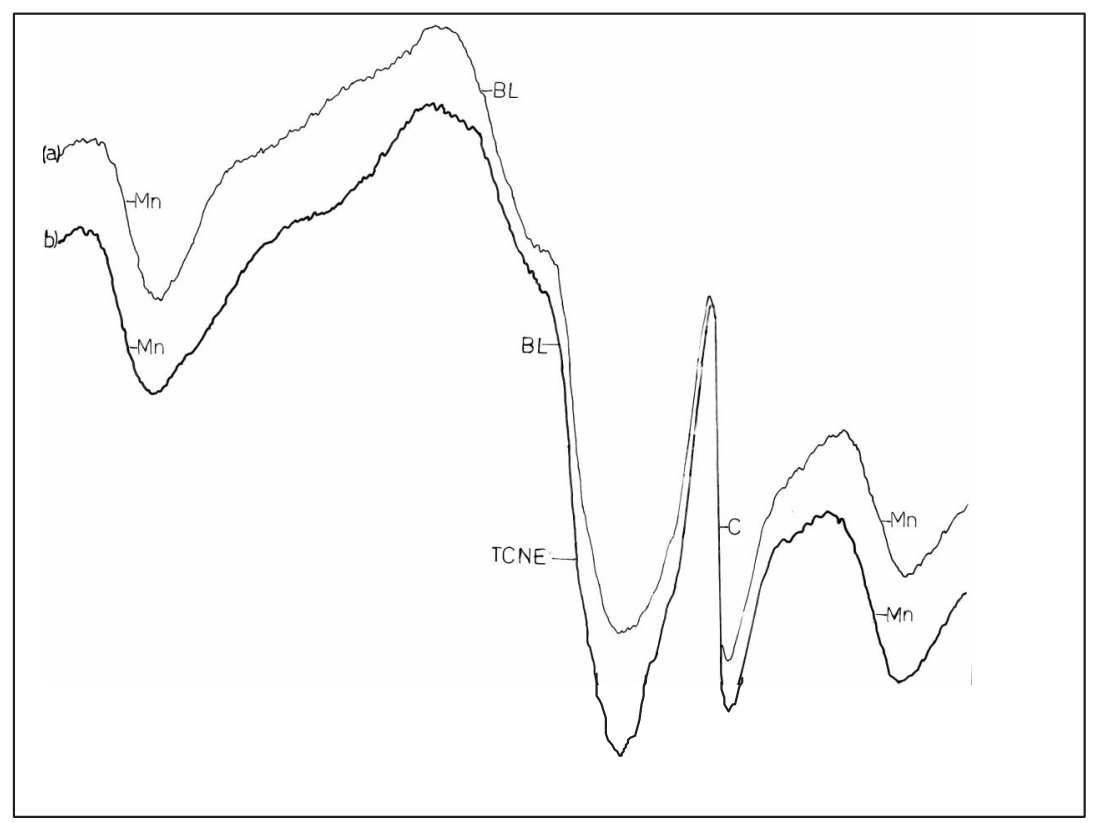

Figure 4. Electron Spin Resonance spectra of a typical calcrete. The BL line was used in dating measurements. For details see Kailath et al (2000).

Kailath et al (2000). The basic advantage offered by ESR is that it dates the precipitation event of a calcrete, whereas the optical dating methods provide ages on the host only. ESR study was carried out at Regional Sophisticated Instrumentation Centre at IIT, Mumbai using a Varian E-112 Eline Century Series X-band ESR Spectrometer with a $100 \mathrm{kHz}$ field modulation. Tetracyanoethylene (TCNE) with $\mathrm{g}=2.00277$ was used as a standard for g-factor measurements. Gamma irradiation dose to various levels up to 2500 Gy was given to sample fractions using cobalt-60 Gamma Cell from BARC with dose-rate of $\sim 31 \mathrm{~Gy} /$ minute. A pre-heat of $50^{\circ} \mathrm{C}$ for $12-14$ hrs was used to isolate the stable signal. A typical ESR spectrum is shown in figure 4 . Of the two lines $\mathrm{BL}$ and $\mathrm{C}$, the former was used as it showed systematic, progressive growth with additive levels of gamma radiation. ESR growth curves (dose rate vs. intensity) of younger and older calcretes are shown in figure 5 . The age is worked out by extrapolating the growth curve to the base line for deriving the equivalent dose and dividing it by the ambient dose rate. Though the shape of the two curves is identical, the older calcrete shows a much higher equivalent dose.

\section{Calcretes in aeolian sediments}

The aeolian sands, unless subsequently enriched, are only weakly calcareous, typically containing 2-4 per cent carbonate. The carbonate occurs as patchy coatings on sand grains and less commonly as discrete sand-sized carbonate grains (Plate 1a). Calcareousness is far greater in $<50 \mu \mathrm{m}$ fraction (silt + clay) in the host sediments, being 18 to $30 \%$ as compared to $<8 \%$ in fine sand fraction and $\sim 3 \%$ in medium sand fraction (table 1 ). Though the fine fraction constitutes less than $10 \%$ of the total sediment, it contributes 27 to $43 \%$ of the total carbonate occurring in the aeolian sands. In the extreme western part, besides carbonate, some gypseous grains also occur.

\subsection{Carbonate profile in dunes}

The stable dunes investigated in this study are analogous to those dated 11 to $16 \mathrm{ka}$ by earlier workers (Chawla et al 1992; Thomas et al 1999). Of the 25 sites examined, none showed a development more than a weakly calcified soil (cf. Netterberg 1969). A few segregations in the form of weakly cemented masses with diffuse boundaries and occasionally as chalky nodules could be seen. Other features were few, fine root casts, amoeboidal 1-2 cm cemented granular masses and platy lenticles of cemented sand. The carbonate profiles of dunes from different locations across the rainfall regime are shown in Figure 6. A trend in relation to mean annual rainfall is obvious. The location with 150-mm annual rainfall had highly restricted leaching but the one with $450-\mathrm{mm}$ rainfall showed pronounced leaching of carbonates, with the top $100 \mathrm{~cm}$ of the profile showing little to no carbonate.

\subsection{Calcretes in accumulative inter-dunes}

Two sections, namely Bidasar $\left(75^{\circ} 18^{\prime} 33^{\prime \prime} E\right.$; $27^{\circ} 51^{\prime} 51^{\prime \prime} \mathrm{N}$, mean annual rainfall $310 \mathrm{~mm}$ ) and 


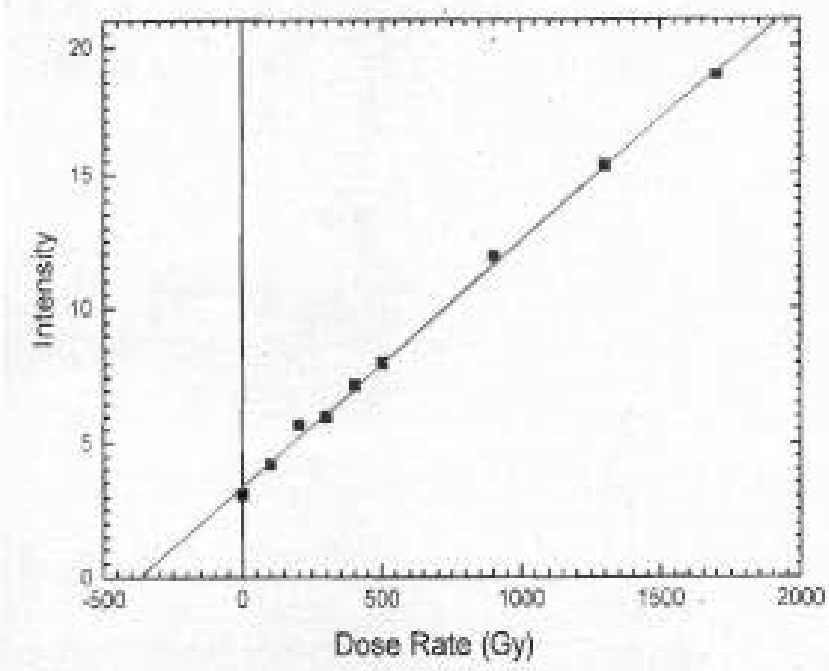

(a)

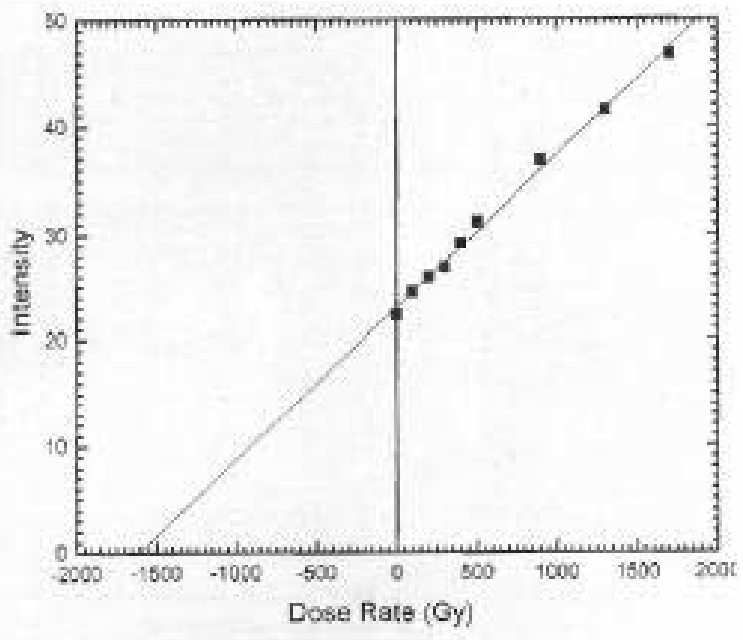

(b)

Figure 5. ESR intensity growth curves with increasing gamma radiation of Banar (a) and Katoti (b) calcretes. The Banar calcrete (mid-Pleistocene) possessed a much lower accumulated dose than the Katoti calcrete (early Pleistocene).

Table 1. Distribution of calcium carbonate in different particle size fractions in aeolian sands as obtained from dry sieving of sample.

\begin{tabular}{|c|c|c|c|c|c|c|c|c|c|}
\hline \multirow[t]{2}{*}{$\begin{array}{l}\text { Site and depth }(\mathrm{cm}) \\
\text { of sample }\end{array}$} & \multicolumn{3}{|c|}{$<50 \mu \mathrm{m}$} & \multicolumn{3}{|c|}{$50-100 \mu \mathrm{m}$} & \multicolumn{3}{|c|}{$100-250 \mu \mathrm{m}$} \\
\hline & $\mathrm{a}$ & $\mathrm{b}$ & c & $\mathrm{a}$ & $\mathrm{b}$ & c & $\mathrm{a}$ & $\mathrm{b}$ & $\mathrm{c}$ \\
\hline Shergarh Dune 260-350 & 19.6 & 1.2 & 27 & 6.1 & 1.2 & 27 & 2.9 & 1.8 & 41 \\
\hline Churu section $400-520$ & 29.8 & 2.4 & 43 & 5.17 & 1.1 & 20 & 3.8 & 2.1 & 37 \\
\hline Gerab 180-250 & 25.7 & 1.5 & 29 & 7.2 & 1.4 & 27 & 3.1 & 1.8 & 35 \\
\hline Bhataru 150-190 & 23.6 & 1.3 & 28 & 5.9 & 1.2 & 26 & 2.0 & 1.9 & 41 \\
\hline Nachana 250-300 & 30.5 & 1.8 & 43 & 8.1 & 1.2 & 29 & 3.6 & 1.2 & 29 \\
\hline Bhikampur 270-350 & 18.8 & 1.8 & 35 & 4.6 & 1.7 & 33 & 2.3 & 1.4 & 27 \\
\hline
\end{tabular}

Note: a. Absolute carbonate in fraction in $\%$; b. Carbonate amount held in the fraction i.e., 'a' $\times \%$ by weight of size fraction; c. Carbonate content in the fraction as $\%$ of the total carbonate content of the whole sample. The fraction over $500 \mu \mathrm{m}$ constituted 6 to $8 \%$ of the sample and its absolute carbonate was less than $1 \%$.

Nachna $\left(71^{\circ} 42^{\prime} 20^{\prime \prime} \mathrm{E} ; 27^{\circ} 27^{\prime} 18^{\prime \prime} \mathrm{N}, 170 \mathrm{~mm}\right)$ were studied. Bidasar possesses two horizons of aggradation with associated calcrete development. The data on carbonate and particle size distribution shows enrichment both in carbonate and fine siliciclastic grains vis-à-vis aeolian sands (figure 7). Only chalky nodules are present. The boundary between upper and lower calcretes is sharp. It is interpreted that each calcrete represents formation related to a discrete event of sediment aggradation, both of carbonate and clastic grains, from the surrounding dunes. The nodules show a looselypacked micrite-spar mass and cavities (plate 1b). Chalky nodules from other sites also show simi- lar features; and these nodules represent an early stage in the process of nodule formation. The Nachna interdune shows a comparable morphology but comprises only of a single aggradation episode.

\subsection{Calcretes in aeolian sandy plains}

Compared to dunes, the sandy plains possess a more pronounced zone of carbonate enrichment at depths ranging from 60 to $100 \mathrm{~cm}$. Of the total carbonate content of 8-13\% in the zone of enrichment, nearly half is present as discrete nodules and the rest is in finely dispersed form. The zone of carbonate accumulation has gradational upper 


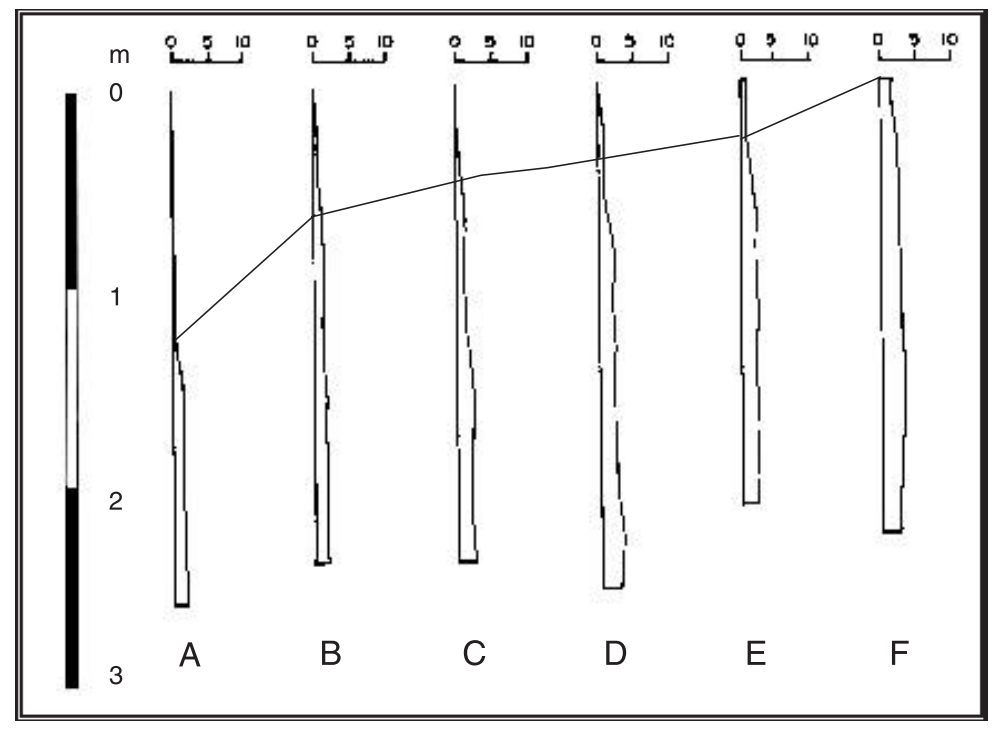

Figure 6. Carbonate profiles in stable, post LGM dunes at various locations in relation to mean annual rainfall: (a)- Jhunjhunu (450 mm), (b)- Churu (350 mm), (c)- Shergarh $(270 \mathrm{~mm})$, (d)- Lunkarnsar (260 mm), (e)-Nachna (170 mm) and (f) -Gerab $(150 \mathrm{~mm})$. Line shows the trend of increasing depth of zone of carbonate accumulation with increasing mean annual rainfall.

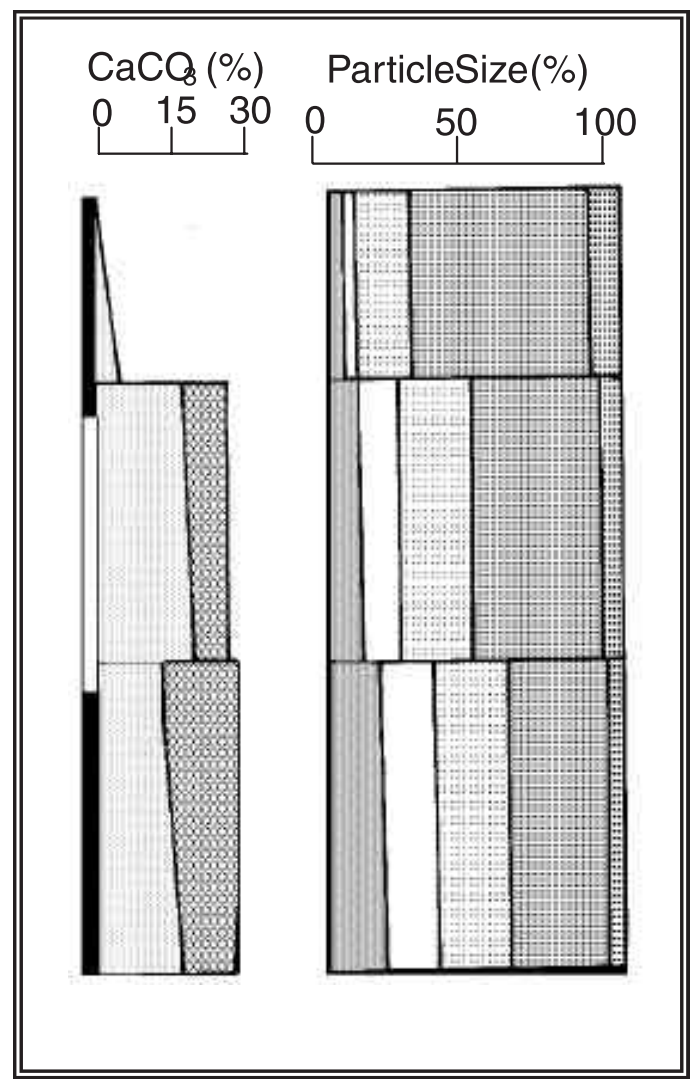

Figure 7. Carbonate profile and particle size distribution data of an accumulative interdune at Bidasar. Key to symbols given under figure 10 .

and lower boundaries and is a typical calcic horizon that develops by leaching of carbonate from overlying soil and its accumulation at a depth cor- responding to the mean wetting front. A striking feature of the sandy plains is the localised occurrence of well-developed calcretes (on an areal scale of a fraction of a square kilometer) that laterally grade into calcretes typical of sandy plains. In deep sections such as at Lorta $\left(72^{\circ} 28^{\prime} 12^{\prime \prime} \mathrm{E} ; 26^{\circ} 42^{\prime} 11^{\prime \prime} \mathrm{N}\right.$; $260 \mathrm{~mm}$ mean annual rainfall), Ratanada $\left(72^{\circ} 29^{\prime} 57^{\prime \prime} \mathrm{E} ; 26^{\circ} 41^{\prime} 46^{\prime \prime} \mathrm{N} ; 260 \mathrm{~mm}\right.$ annual rainfall $)$ and Genana $\left(74^{\circ} 21^{\prime} 20^{\prime \prime} \mathrm{E} ; 26^{\circ} 21^{\prime} 45^{\prime} \mathrm{N} ; 350 \mathrm{~mm}\right)$ a stack of two to three calcretes is observed. Unlike the calcretes of the interdunal areas, these localised formations in the aeolian sandy plains show an extra-ordinary enrichment in carbonate but without an accompanying increase in silt and clay, implying that the carbonate enrichment is by a mechanism different from that in the interdunes. Further, the boundary of the individual calcrete units is nearly horizontal. Consequently, enrichment here occurred from shallow groundwater, which accumulated in local topographic lows by seepage from the surroundings. The inferred sequence of events is: deposition of aeolian sand sheet followed by carbonate enrichment from groundwater, and then development of nodules through local redistribution of carbonate after recession of the water table. Another aeolian sand aggradation and a repetition of the process led to the formation of the next stacked sequence.

\subsection{Calcretes in aeolian sand on piedmonts}

The aeolian sands developed on piedmonts show a stronger development of calcrete in terms of profile thickness and the frequency of nodules in 


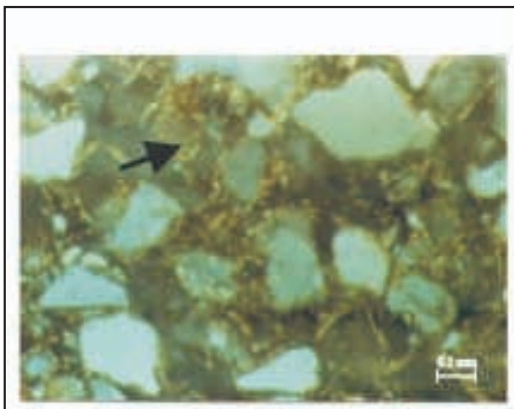

(a)

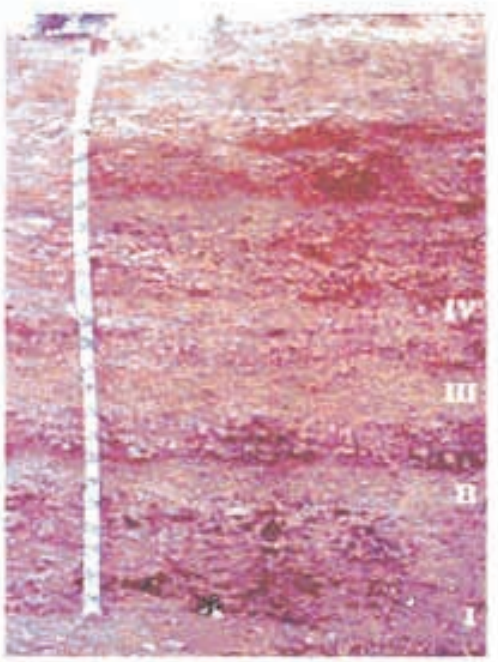

(c)

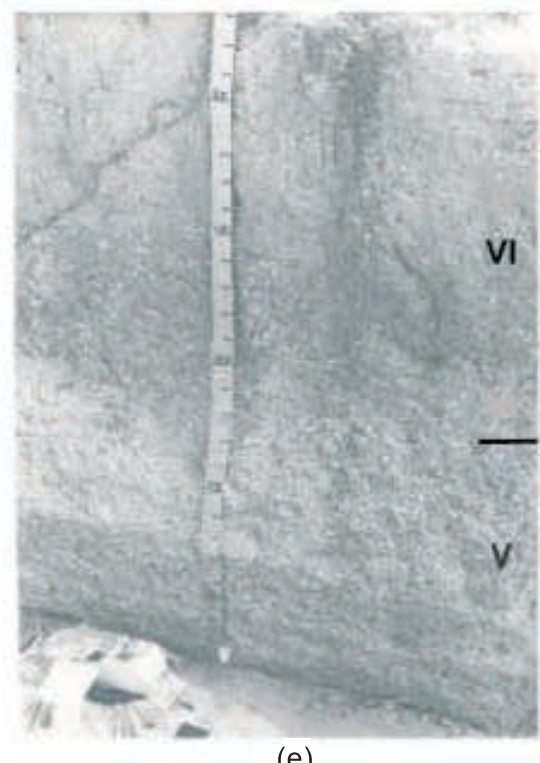

(e)

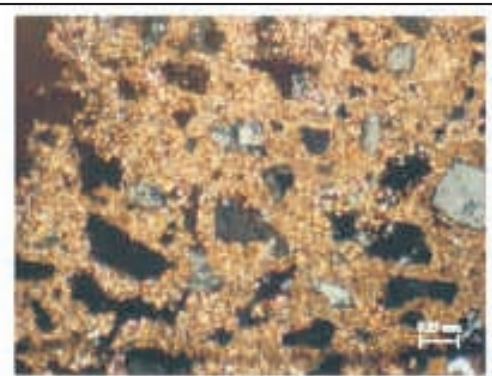

(b)

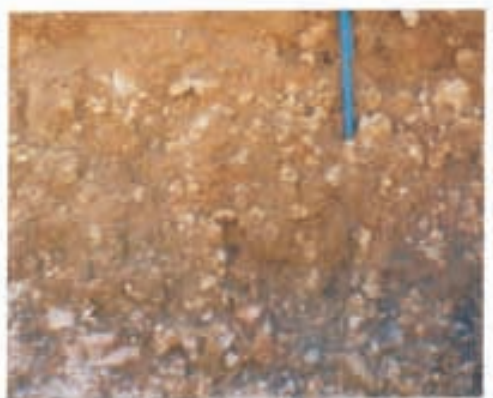

(d)

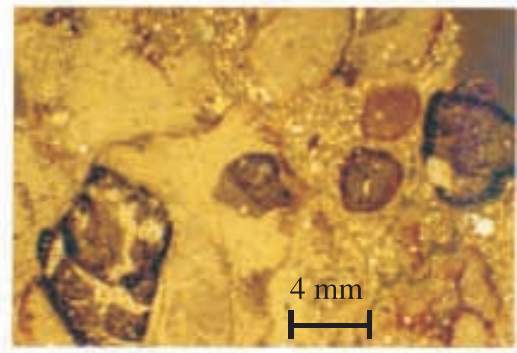

(f)

Plate 1. (a) Photomicrograph of an aeolian sand. Note patchy carbonate coating on sand grains and an occasional sand sized carbonate grain (arrow mark). The silt-sized grains are calcareous; (b) Photomicrograph of a chalky nodule from interdunal calcrete at Bidasar. Note the micritic, locally sparitic, loosely packed groundmass and some large sized cavities; (c) Field view of section at Trijunction. It comprises alternating aeolian sandsheets and colluvial aggradation units in the $3 \mathrm{~m}$ exposed section. The aeolian units have nodular calcrete whereas colluvium has carbonate coating on gravels and occasional nodule; (d) Close-up of nodular calcrete in aeolian unit III in the Trijunction section. Pen for scale is $12 \mathrm{~cm}$ long; (e) Field view of Chamu section showing units V and VI. Unit V is entirely a calcrete whereas unit VI has a calcrete in its lower half that grades upwards into a zone of carbonate depletion; (f) Photomicrograph of cemented, gravelly alluvium (unit I) of Chamu. The gravels are mainly transported nodules. Note the variety and rounded form of nodules. Their dark brown calcitic groundmass and calcite-filled shrinkage cracks are distinctive features vis-á-vis that in the nodules of units $\mathrm{V}$ and VI. 


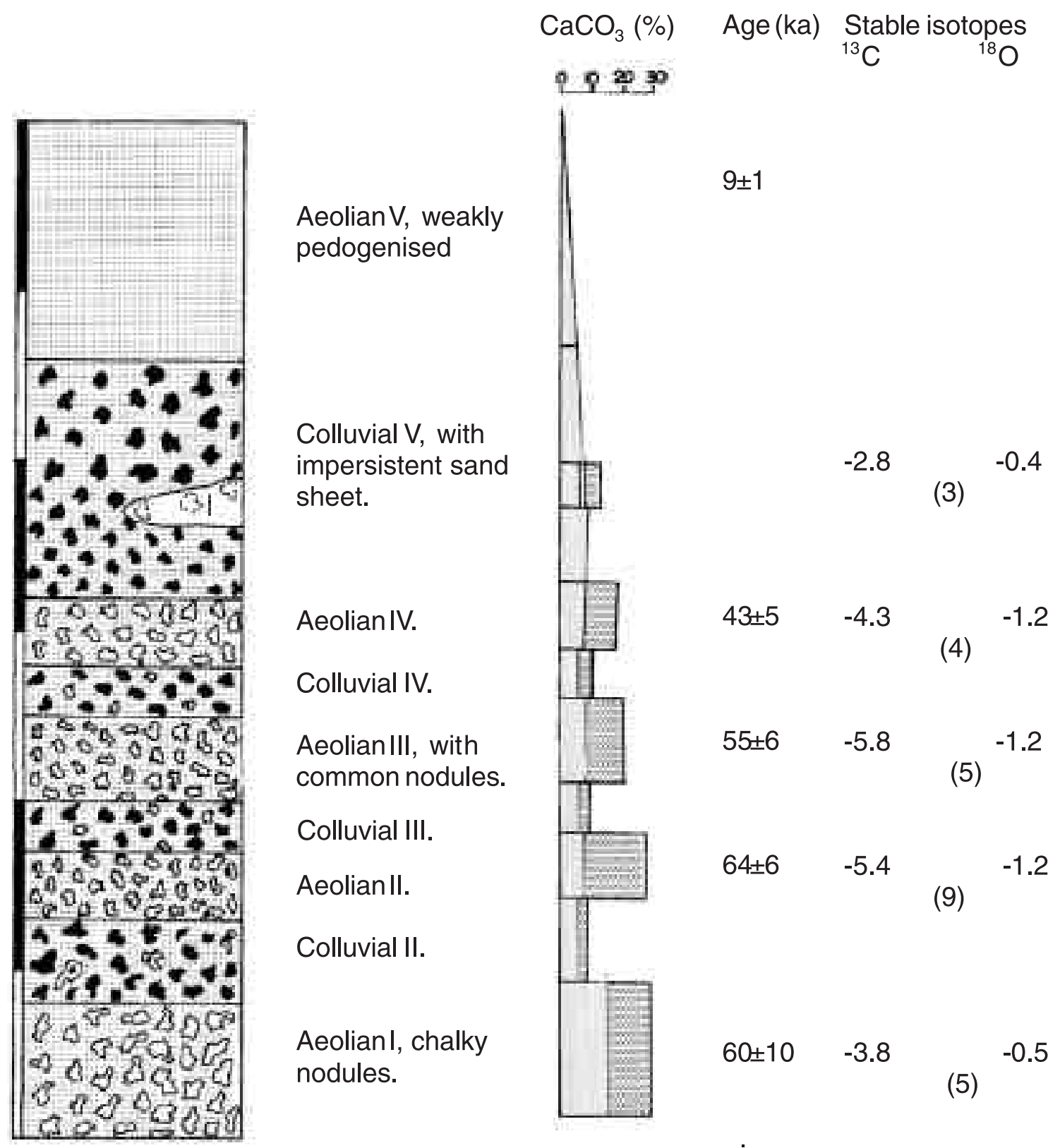

Figure 8. Log of Trijunction section, a piedmont comprising alternate bands of Aeolian sandsheet and colluvium. The ages (TL/IRSL) are on feldspar in sand. The gravels are coated with carbonate.

comparison with those described earlier. This is apparently due to enhanced dust-sourced carbonate supply from the rocky catchment. Two situations are observed:

- aeolian sediments that occur as a sheet in between colluvial units and

- aeolian sediments that have been reworked together with a variable mixture of locally derived clasts.

The Trijunction section represents the former situation.

The Trijunction section consists of calcretes in an alternating sequence of colluvial and alluvial units developed off a rhyolite hill $\left(72^{\circ} 25^{\prime} 26^{\prime \prime} \mathrm{E}\right.$; $26^{\circ} 26^{\prime} 08^{\prime \prime} \mathrm{N}, 260 \mathrm{~mm}$ mean annual rainfall). The section comprises five aeolian units separated by colluvial units (plate 1c; figure 8). With the exception of unit $\mathrm{V}$ at the top, all the individual aeolian units contain well-developed nodular calcrete (plate 1d). The nodules are chalky to hard. The colluvial units are mostly gravelly with $<10 \%$ aeolian sand. The gravels are coated with carbonate and are locally cemented. Occasionally, a nodule or rhizolith occurs. Sand sheets I to IV have been dated to $60-70,55-60$, 45-55 and 25-45 ka respectively (Andrews et al 1998). 
Analysis of calcretes shows that $\delta^{13} \mathrm{C}$ values range from 0 to $-1.8 \%$ whereas the $\delta^{18} \mathrm{O}$ values show a larger spread of values from -2.1 to $-6.5 \%$. Closely spaced sampling of the nodules here indicated a systematic trend with clear evidence of calcretes of units I and IV ( $\delta^{18} \mathrm{O}$ values of 2.1 to $4.6 \%$ ) having formed from more evaporated continental rain water (i.e., weaker monsoon). Units II and III ( $\delta^{18} \mathrm{O}$ values of -4.6 to $\left.-6.5 \%\right)$ developed from less evaporated monsoonal rain water (Andrews et al 1998).

Osian II section $\left(72^{\circ} 55^{\prime} 36^{\prime \prime} \mathrm{E} ; 26^{\circ} 42^{\prime} 17^{\prime \prime} \mathrm{N}\right)$ lies off a sandstone hill and is developed in reworked aeolian sands. The 3-meters deep section has $80 \mathrm{~cm}$ thick upper unit that comprises transported nodules and clasts of sandstone admixed with aeolian sands. The lower unit is entirely in aeolian sands and comprises somewhat hard nodules that grade with depth into chalky lumps. Thin sections of nodules show micritic-microsparitic mass with some clay-carbonate domains.

\subsection{Chamu multiple calcrete section}

This section $\left(72^{\circ} 35^{\prime} 32^{\prime \prime} \mathrm{E} ; 26^{\circ} 40^{\prime} 16^{\prime \prime} \mathrm{N}, 270 \mathrm{~mm}\right.$ rainfall) occurs in a hummocky sandy plain in association with dunes. Aeolian sediments in the plain are 5 to 15 meters thick and overlie a cemented, gravelly alluvial stratum. The Chamu section lies to the northeast of a high dune and is exposed in a 1500-meter long trench dug for a canal. It comprises seven lithounits (figure 9, plate 1e), of which unit I at the base is a whitish, semi- consolidated channel deposit comprising reworked carbonate nodules. Its thin section shows the presence of a variety of nodules, not found in the overlying units (plate 1f). Some nodules show a dark brown dense micrite with shrinkage cracks filled with whitish spar that attests to their complex history. The remaining six units are all aeolian sands. Unit II (IRSL date $157.3 \mathrm{ka}$ ) is compact, dense, somewhat poorly sorted aeolian sand with abundant nodules (15-25\% of bulk sample). Unit III (undated) is very dense, weakly calcareous with patchy nodular calcrete in the upper $15-20 \mathrm{~cm}$. Unit IV is a few meters thick and has age values of 81 to $105 \mathrm{ka}$. However, if we take note of the uncertainty level of the estimate, an age bracket of 90-100 ka seems reasonable. It has at the base, locally impersistent carbonate cemented lenses (plate $2 \mathrm{a}$ ) and rhizocretions (plate 2b); and in the middle part 4 to 5 laterally impersistent, horizontal carbonate cemented bands, 10 to $20 \mathrm{~cm}$ thick (plate 2c). The upper part of this unit has a patchy nodular calcrete. Unit V (58-62 ka) is made up entirely of nodular calcrete with the nodules forming 15 to $35 \%$ by weight of the total mass. Unit VI, $\sim 3$ meters thick, has an age of $27 \mathrm{ka}$ at the base and becomes progressively younger to $14 \mathrm{ka}$ towards the top. Its lower half has few scattered, chalky nodules and it grades upwards into a weakly calcareous solum. With the exception of a few fine root casts, unit VII $(0.06 \mathrm{ka})$ is devoid of any carbonate segregation.

Thin section studies show that the inter-nodular host sediments of unit $\mathrm{V}$ consist of closely packed sand grains with grain-to-grain contacts (plate 2d), but locally impregnative carbonate infillings are present. Occasional sand-size carbonate grains are also present. In comparison the nodules show host sand grains floating in a whitish to brown micrite mass with local zones of spar (plate 2e). Clastic grains exhibit spar corona. Plagioclase grains show corroded margins. The nodules and earthy matter of units IV and VI are similar to unit $\mathrm{V}$ described above, except that grain coronas are weakly expressed or absent altogether. The cemented lensoid features as well as hardpan have siliciclastic grains only slightly floating in a sparite, locally micrite, groundmass. The calcitic mass here is uniformly light coloured and unlike that in the nodules described earlier.

The EPMA results show that the whitish micrite in the nodules of unit $\mathrm{V}$ comprises almost entirely of calcite. The brown micrite has traces of silicate clay whereas dark brown micrite is calcite with considerable amount of clay. Occasionally free $\mathrm{Al}_{2} \mathrm{O}_{3}$ is also present. Clay mineral analysis of the unit VII consisting of recent aeolian sand without calcrete development showed dominance of smectite and mica, and minor kaolinite and chlorite. Palygorskite constituted $<10$ per cent only. In comparison, the inter-nodular sand in unit VI showed appreciably more amount of palygorskite. The nodules in the units VI and V possessed even higher content (18-25\%) of this mineral. Its presence was additionally confirmed by scanning electron microscopy (plate 2f). The mineral occurs as a fibrous mat in calcite groundmass and as bridges between grains. Isotopic measurements of this section are in progress and will be presented elsewhere. Overall the evidence suggests values similar to those found in sheetwash and aggraded plain calcretes.

\section{Inferences on calcretes in aeolian sands}

- The post-LGM dunes possess weak, powdery, rarely chalky nodular, calcretes. The associated interdunes with calcareous, silty sand host have chalky nodular calcretes of considerable thickness. Progressive thickening of calcretes from the dune form to the center of the interdunes suggests occasional runoff as a contributing mechanism for the extraordinary enrichment of the interdunal aeolian sands in silt and carbonate. 


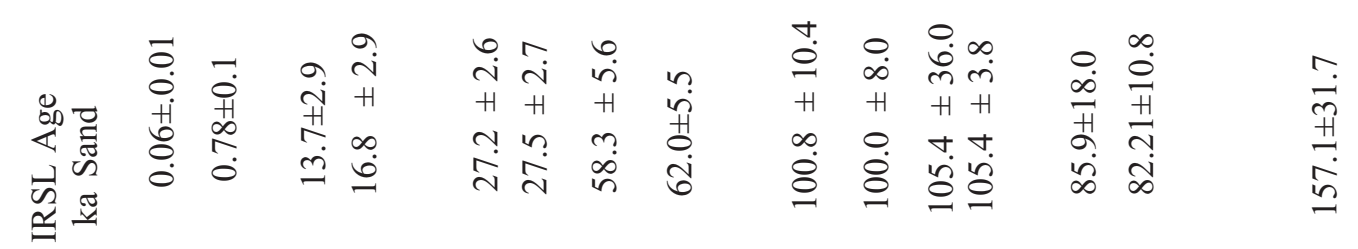

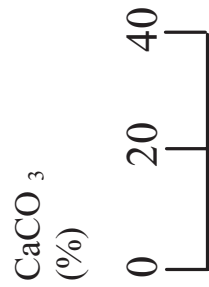

$\frac{\pi}{3}$

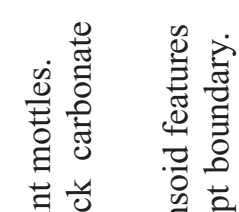

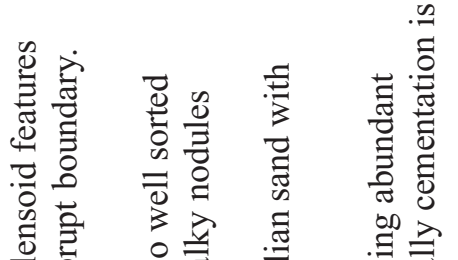

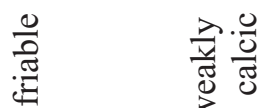

궁

3

乎

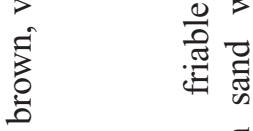

吗高

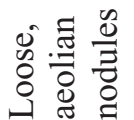

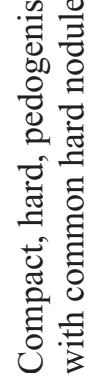

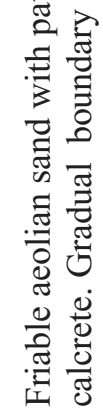

恖总

壳 च च

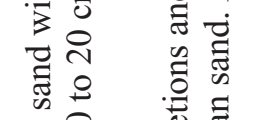

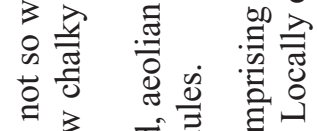

氙总 矛吾

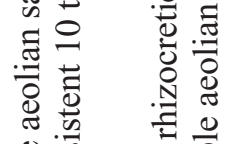

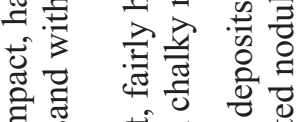

हี

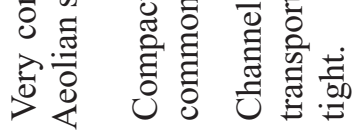

>

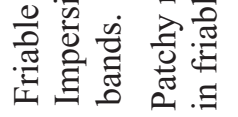




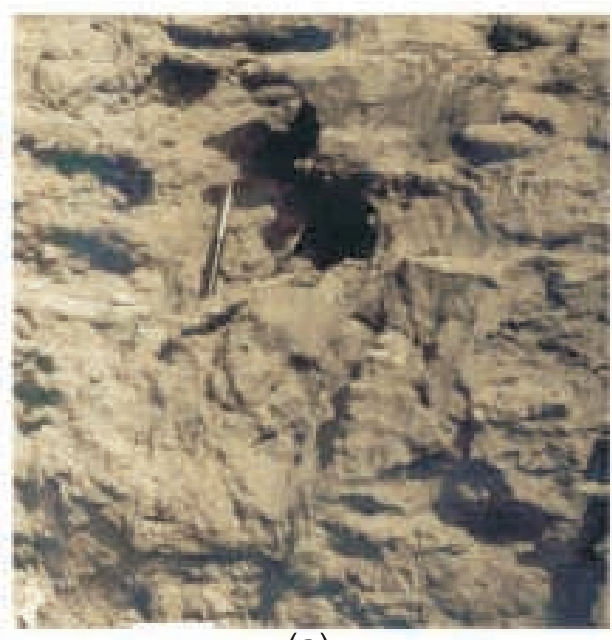

(a)

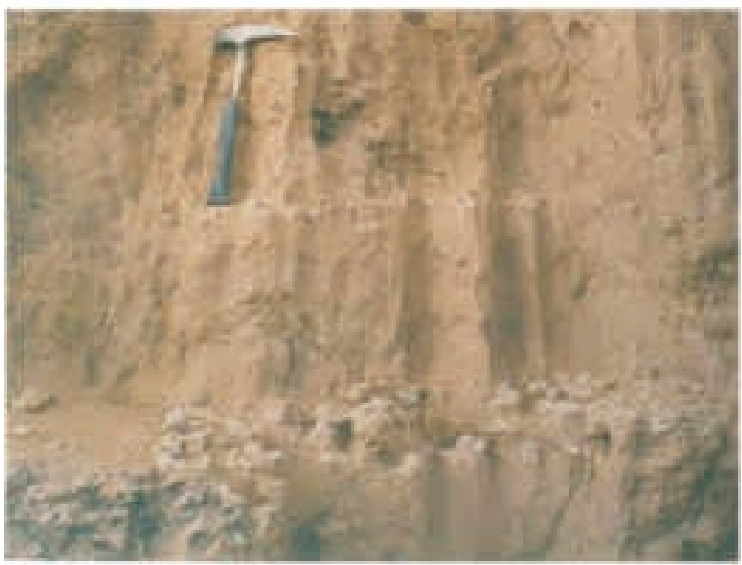

(c)

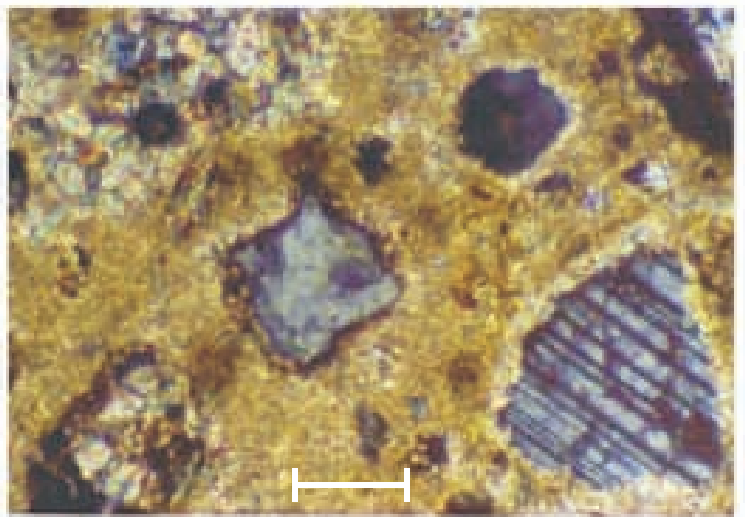

(e)

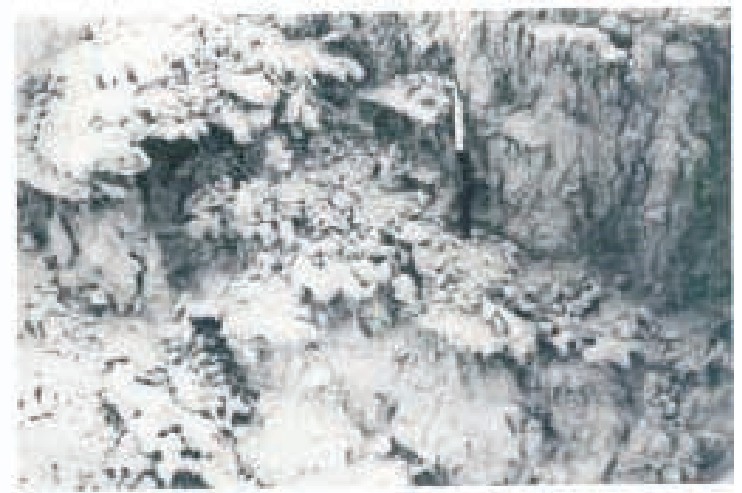

(b)

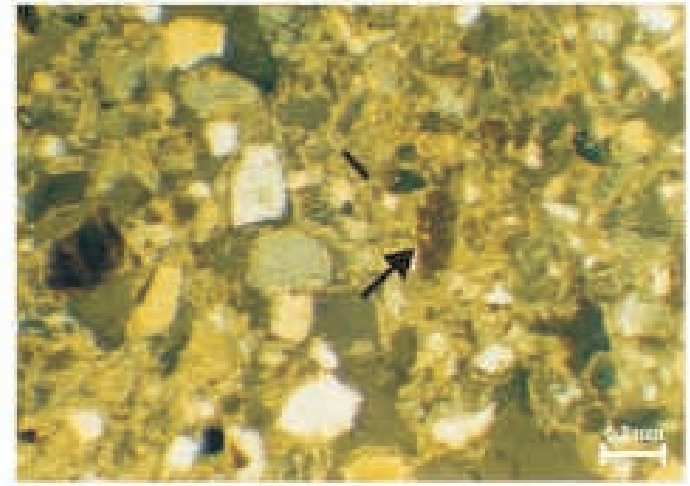

(d)

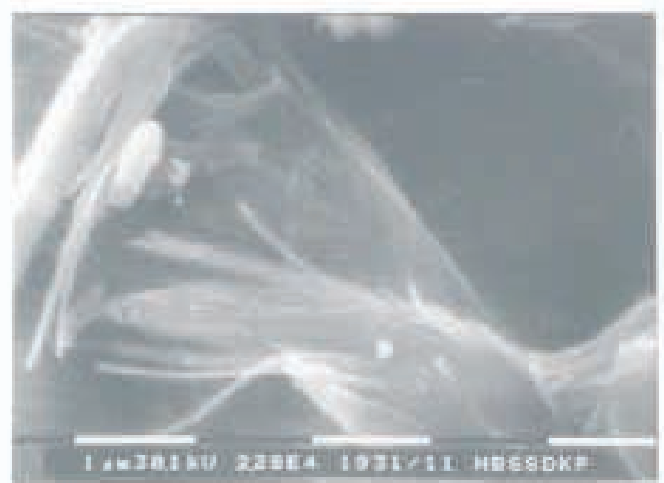

(f)

Plate 2. Chamu section. (a) Cemented lensoid features at the base of unit IV. Their development is related to perched watertable. Pen for scale is $10 \mathrm{~cm}$ long; (b) Rhizolith features at the same depth as that of lensoid features: an outcome of phreatophytic vegetation and perched water table. Pen for scale is $10 \mathrm{~cm}$ long; (c) Carbonate-cemented groundwater bands in middle part of unit IV. The bands are 10 to $20 \mathrm{~cm}$ thick and extend laterally for 50 to 100 meters. Hammer is $30 \mathrm{~cm}$ long; (d) Photomicrograph of inter-nodular soil of unit V. Note an impregnative carbonate infilling (X) and a sand-size carbonate grain (arrow); (e) Photomicrograph of nodule from unit V showing clotted micrite and intergrown spar groundmass. Host sand grains show development of spar corona. Plagioclase grain shows corrosion; (f) SEM photograph of neoformed palygorskite from nodule of unit V. The fibrous habit is a characteristic feature of this mineral (scale bar division $-1 \mu \mathrm{m})$. 
Thick calcretes on piedmonts off the hills and large rocky outcrops are possibly a case of secondary enrichment with carbonate dust being 'washed in' together with the coarser clasts from the catchment. Patches of strongly developed calcretes in sandy plains gradually merge into weaker calcretes. These have an abrupt planar boundary with the overlying calcrete or sands and point to a groundwater source for the carbonate enrichment, though the nodule development was a subsequent process.

- The Chamu section shows a sequence of calcretes, which have developed in time-separated aeolian sand aggradations at $\sim 150, \sim 100, \sim 60$ and $27-14 \mathrm{ka}$. The calcrete bearing strata have 10-20\% carbonate; thus a considerable enrichment of original host is evident. The level at which these calcretes occur suggests the absence of any influence of groundwater. The terrain and relief precludes sheet flow as a process. Unit VI clearly has a depleted upper solum, which gradually grades into a zone of carbonate enrichment. It is a typical, pedogenic calcrete profile with a calcic horizon that develops by profile redistribution of carbonate. Unit V presently does not possess a zone of depletion and comprises entirely of a nodular calcrete. But, evidence exists that such a zone was present and was stripped off. Firstly, a thin band of reworked nodules is seen separating units V and VI and the same is present locally also between units IV and V. Secondly, the unit $\mathrm{V}$ shows slopes characteristic of a paleodune flank, much of which has been denuded away. Therefore, there is strong evidence that units IV and $\mathrm{V}$ formed also by this vertical redistribution of carbonate, but the upper zone of eluviation was stripped away. However, the intact basal part, strengthened by the calcrete could withstand this erosional episode. This is not surprising since aeolian landscapes are highly dynamic and sediment thicknesses of a few meters can be added or denuded in a short time. In Australia, Arakel (1982) described denudation and reworking of exposed calcretes as the dominant feature of calcrete profiles in the dunes.

- A major part of carbonate in the enriched zone is present in the form of nodules. This suggests that a local redistribution of carbonate into nodules is a characteristic diagenetic feature in the zone of enrichment. The presence of chalky nodules in younger calcretes and of transitional stage between chalky and hard nodular form (Unit VI) show that chalky forms are an early stage in the evolution to hard nodules. The process of calcrete development is accompanied also by neosynthesis of palygorskite.

\section{Sheetwash aggraded plain calcretes}

Sheetwash aggraded plains host well-developed nodular calcretes. In a typical profile, the nodules comprise 50 to $80 \%$ by weight of total calcrete mass. The inter-nodular earthy mass is calcareous also. Four sections were studied in detail. Of these, the Osian-I $\left(72^{\circ} 57^{\prime} 41 \mathrm{E} ; 26^{\circ} 38^{\prime} 19 \mathrm{~N}\right)$ is a 450 meter long trench. The 3 -meter deep section shows a stack of three calcretes, each with abundant hard nodules. The lowest calcrete has an undulating, fairly persistent thin band comprising nodules that are tightly cemented by a younger generation calcite. The upper and middle calcretes have ESR ages of 162 and $278 \mathrm{ka}$. The Nandia Khurd section $\left(73^{\circ} 12^{\prime} 68^{\prime \prime} \mathrm{E} ; 26^{\circ} 47^{\prime} 37^{\prime \prime} \mathrm{N}\right)$ is a 6.5 -meter excavation that exposes a stack of five calcretes, the one at the top is capped by aeolian sands. The boundary between the calcretes is distinct. The lowermost part of the section comprises calcrete with a lumpy, chalky character. This is overlain by carbonate-cemented and poorly sorted, channelbed sediments. The upper part comprises a succession of three calcretes (units III, IV and V). The calcretes in units IV and V are dated to 371 and 245 ka respectively.

\subsection{Banar section}

The site $(\sim 1.5 \mathrm{~km}$ to the east of village Banar; $73^{\circ} 09^{\prime} 41^{\prime \prime} \mathrm{E}$ and $26^{\circ} 19^{\prime} 30^{\prime \prime} \mathrm{N}$ ) occurs in the form of a cluster of large sized quarries spread over nearly $3.5 \mathrm{~km}^{2}$. Exposed sections show persistence of individual calcrete units across the quarries. A thin mantle of aeolian sands covers the section. It comprises three lithounits (figure 10 and plate 3a), of which units I and II represent sheetwash deposits whereas unit III at the top is in aeolian sand. The contact between the litho-units is distinct and often marked by the presence of fine $(0.1$ to $0.4 \mathrm{~cm})$, rounded nodules, which are clearly of transported nature. Units II and III contain well-developed calcrete with 65 to $80 \%$ of the carbonate mass constituted by nodules that are hard, sub-spherical to weakly elongate in shape, and 2 to $5 \mathrm{~cm}$ in length. In places, nodule size may reach $10 \mathrm{~cm}$. The nodules have a knobby or mammilated surface resulting from subsequent dissolution and degradation. Few rhizoliths are present. At the base of the unit II is a thin band comprising tightly cemented nodules. The band extends laterally for 10 to 30 meters with a gently wavy disposition. Unit I mostly comprises chalky lumps (plate 3b) with yellowish brown inter-lumpy material, which becomes whitish on drying. The lumps become fewer with depth and the stratum grades into an undifferentiated, cemented original material. The nodules in the top unit (calcrete III) have been 


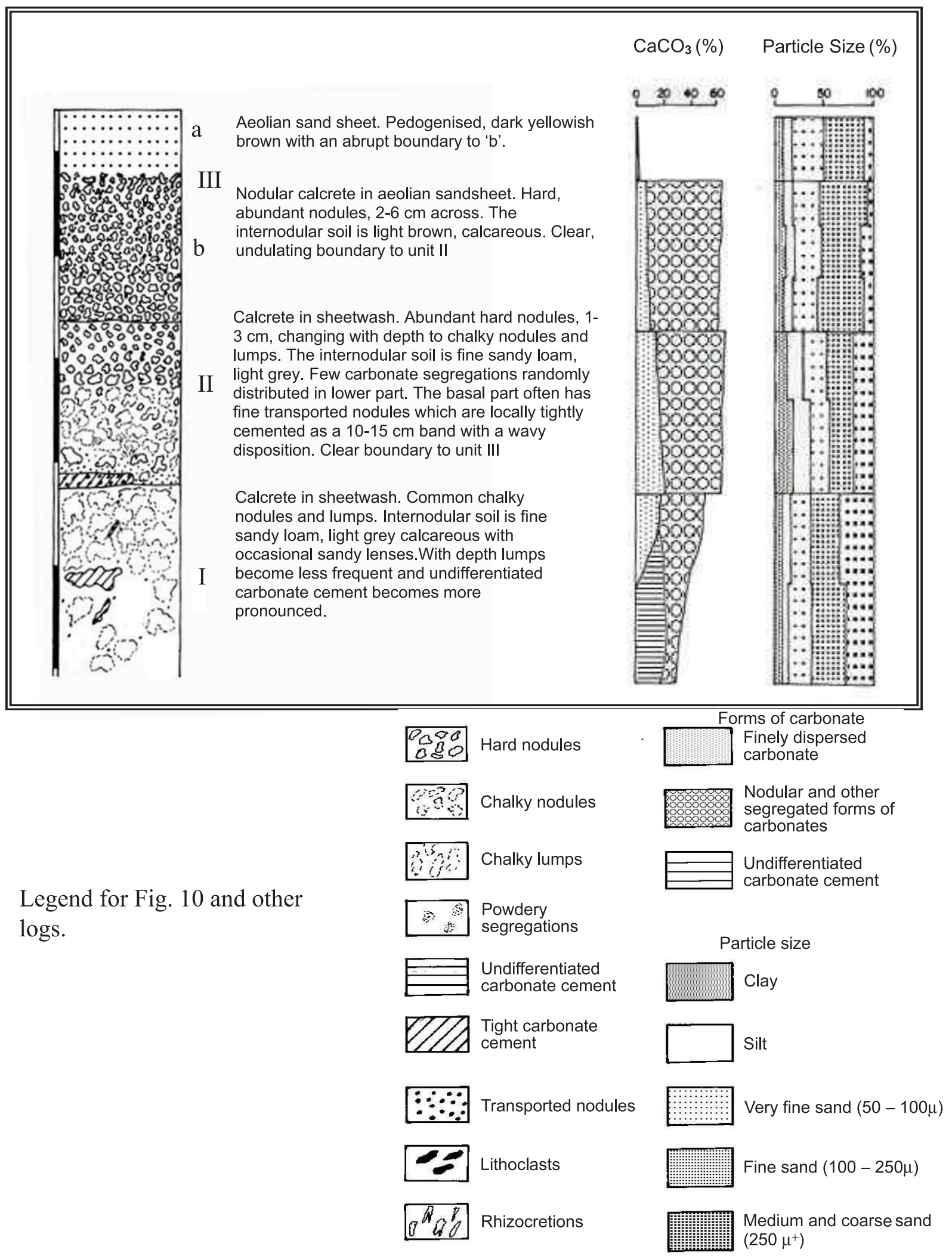

Figure 10. Banar section showing a stack of three calcretes in sheetwash (field log and laboratory data). Note that the unit III is in sandsheet. The nodules are formed in situ, though few transported nodules are seen at the base of individual calcretes. Calcrete in Unit III and Unit II are ESR dated to 114 and 340 ka respectively. 


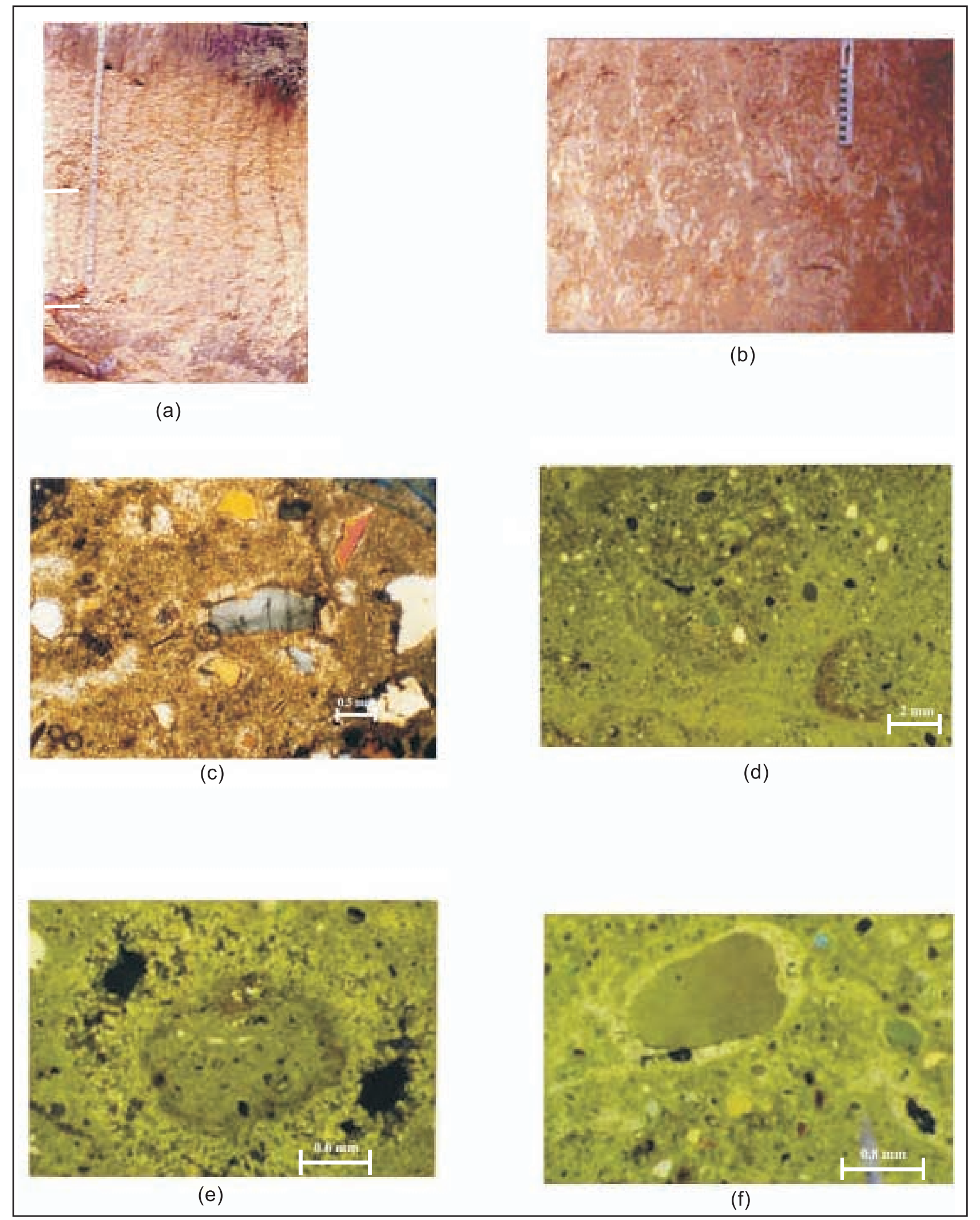

Plate 3. (a) Field photo of Banar section comprising a stack of three calcretes. Note the pronounced nodule form that is a characteristic feature of most sheetwash aggraded plain calcretes; (b) Close-up of Unit I showing the irregular shaped lumps. These, like the nodules, are interpreted to evolve from undifferentiated, cemented host sediments; (c) Photomicrograph of a nodule from Unit III showing calcitic groundmass comprising micrite with intergrown spar. Micrite often has some associated clay. The spar in shrinkage cavities is an open space growth; (d) Locally, the calcitic groundmass tends to organize into mottles, often with a clay-rich rim: (e) A mottle surrounded by a spar halo; (f) Photomicrograph of a nodule showing a circumgranular crack filled with spar. 
dated to $114 \mathrm{ka}$ and those in the underlying unit (calcrete II) to $340 \mathrm{ka}$ (Table 4).

\subsubsection{Carbonate content and particle size distribution}

Calcretes in units II and III have $\sim 60 \%$ carbonate, a major part of which is in the form of nodules (figure 10). Total carbonate in Unit I is a little less and with depth it is around 35\%. Dilute acid digestion of nodules yields $10-15 \%$ of residue, the rest being carbonate. Analysis of the filtrate indicated calcium as the main constituent with magnesium constituting less than 2 per cent. The lumps have 25 to 40 per cent of carbonate. The particle size data (figure 10) shows that units I and II (sheetwash) have only moderate amount of silt and clay, and in unit III (aeolian) the values are even lower.

\subsubsection{Carbonate petrography}

Individual nodules of unit III occur as discrete, disorthic features. In thin section, the nodules have a clotted micrite groundmass with inter-grown spar in which the clastic grains are widely dispersed (plate 3c). The groundmass is white to brown. An interesting feature is that micrite groundmass shows a local organization into mottles. Various stages of organisation ranging from incomplete to complete differentiation are seen (plate $3 \mathrm{~d}, \mathrm{e})$. At places there is a well-developed spar halo. The clastic grains, almost entirely quartz with occasional weathered feldspar, show corroded margins with well-developed corona. The corona comprises elongated, bladed spar. Few opaque dendrites are also seen. Shrinkage and circum-granular cracks lined/filled with spar are common (plate 3f). CL study showed that the undifferentiated calcitic groundmass has varied luminescence pattern. The spar corona around the siliciclastic grains and spar cavity-fill is invariably non-luminescent. The groundmass is dull orange luminescent to nonluminescent (plate 4a,b). The nodules of unit II exhibit similar features except that dark dendrites are few. The lumpy calcrete (unit I) shows a simple fabric comprising spar cement and siliciclastic grains (plate 4c). The density of packing of grains is much greater than that in the nodules described above. Besides, other features, like corona development, shrinkage features or organization of groundmass into mottles are absent here.

\subsubsection{EPMA}

Different petrographic features as discernible in thin sections of various units were analysed. Each feature was analysed at $15-20$ points. Pure calcite has a $\mathrm{CaO}$ value of $56 \%$ in EPMA. Pure clays normally contain 45 to 60 per cent of $\mathrm{SiO}_{2}$ and about 20 to 30 per cent $\mathrm{Al}_{2} \mathrm{O}_{3}$. Besides, some $\mathrm{MgO}$, interlayered water molecules are present. Soil clays invariably contain some $\mathrm{Fe}, \mathrm{K}$ also. Therefore, in our interpretation the presence of both $\mathrm{Si}$ and $\mathrm{Al}$ is taken as indicative of clays. Presence of either element $\mathrm{Al}$ and $\mathrm{Si}$ in more than a ratio of $2: 1$ has been interpreted as presence of these elements in free form. Data on nodules from unit III are given in table 2 as an illustration. The results show that the whitish to light grey micrite-spar groundmass in nodules has 93 to 95 per cent calcite with traces of silica. The brown calcite shows a minor admixture with clay. Occasionally, extraordinary concentrations either of aluminum or silica are also seen. The very dark opaque areas in the form of dendrites are made up of $\mathrm{MnO}_{2}$. Besides, considerable spatial variation is seen both in Fe and Mn content, the relationship being generally of anti-correlation. Nodules in unit II show similar results. Unit I, i.e., lumpy calcrete showed considerable presence of dolomite also.

\subsubsection{Clay mineralogy}

An X-ray diffractogram of a clay sample from nodules of unit II calcrete is illustrated in figure 11. Clay fraction from other units presented an identical picture. It shows a prominent peak of palygorskite at $10.4^{\circ} \mathrm{A}$, with a low shoulder to its left due to mica. Presence of smectite and kaolinite is also indicated. A semi-quantitative estimate of clay mineral composition derived from X-ray diffractograms of samples from various units is presented in table 3 . The aeolian sand sheet that is unaffected by calcrete (Unit IIIa) shows a mixture of minerals comprising smectite, mica, kaolinite, chlorite and $10-15 \%$ of palygorskite. The calcrete developed in unit (IIIb) shows that the nodules and the inter-nodular soil have a larger amount of palygorskite. Unit II calcrete shows an even higher concentration of palygorskite. Thus a trend of progressive increase of palygorskite with depth is obvious. Increase in palygorskite is accompanied by a decrease in other clay minerals. Besides mats in the calcitic groundmass, palygorskite is observed in pore spaces (plate 4d). Stable isotope composition of Banar and other calcretes is described later.

\subsection{Sunari section}

This section (450 m long and $250 \mathrm{~m}$ across) is located in a large quarry $4 \mathrm{~km}$ to the west of Ladnun $\left(74^{\circ} 21^{\prime} 25^{\prime \prime} \mathrm{E}\right.$ and $\left.27^{\circ} 38^{\prime} 19^{\prime \prime} \mathrm{N}\right)$, (figure 3 ). It 


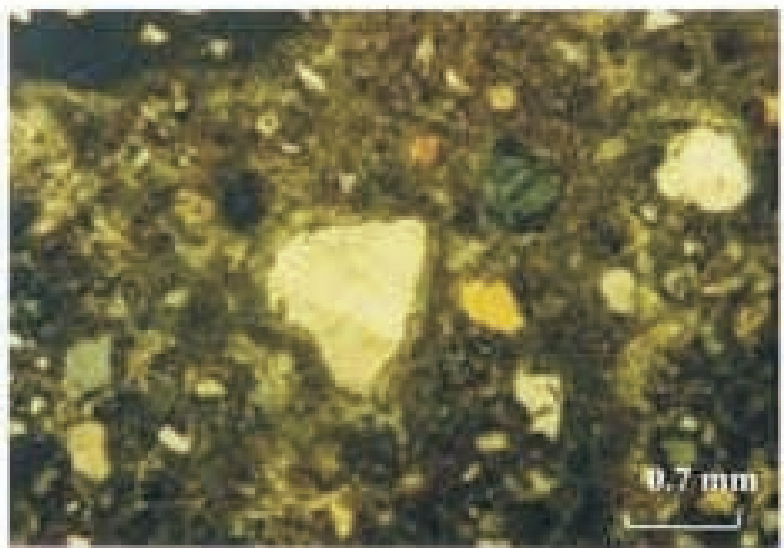

(a)

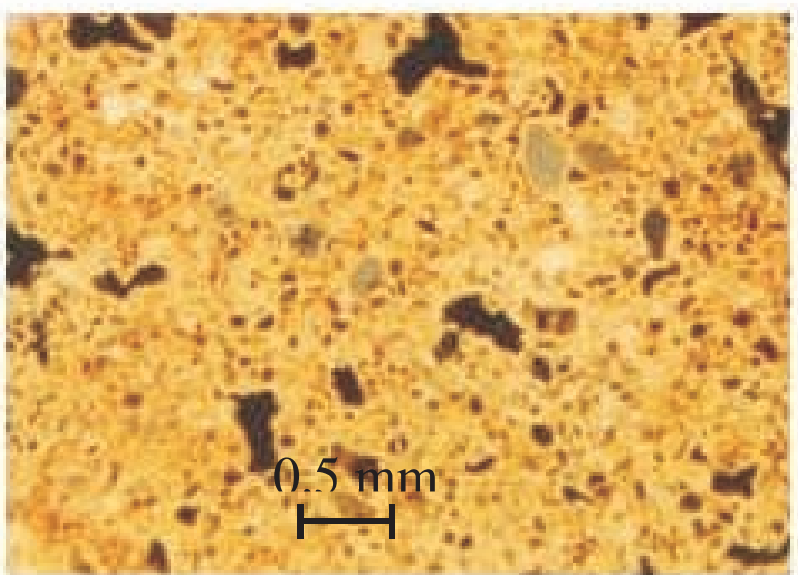

(c)

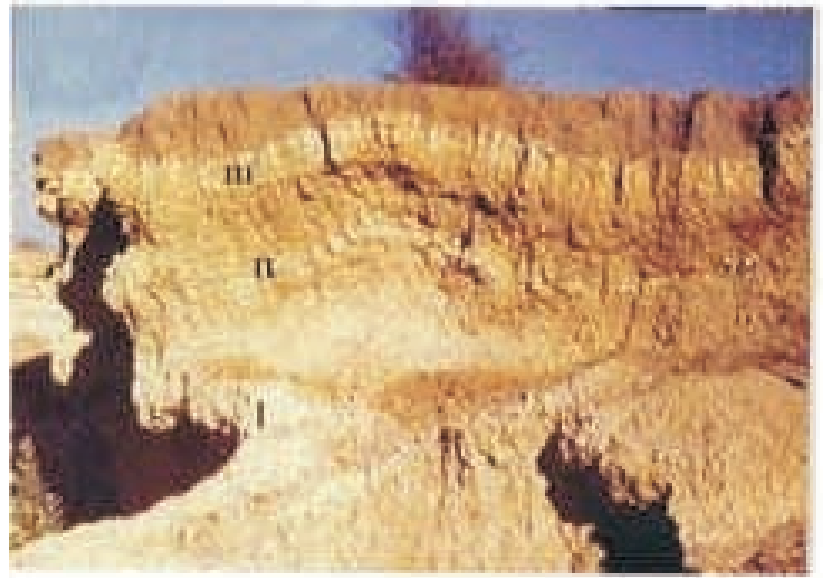

(e)

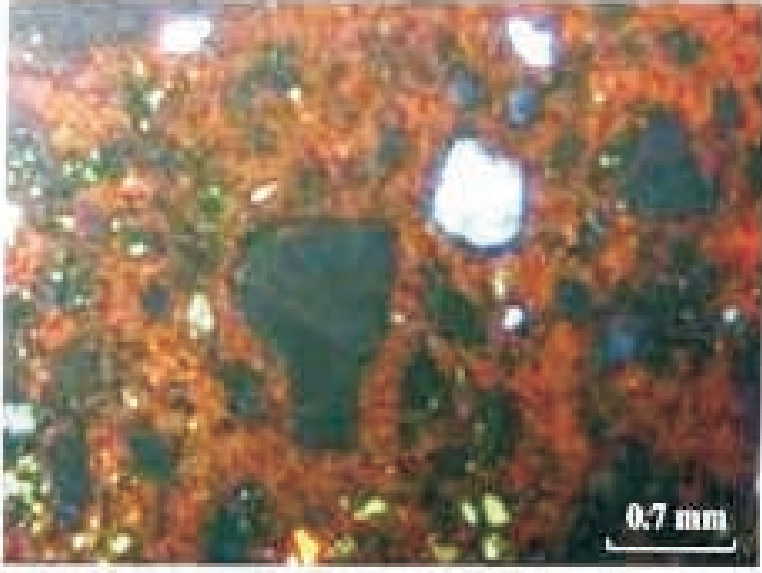

(b)

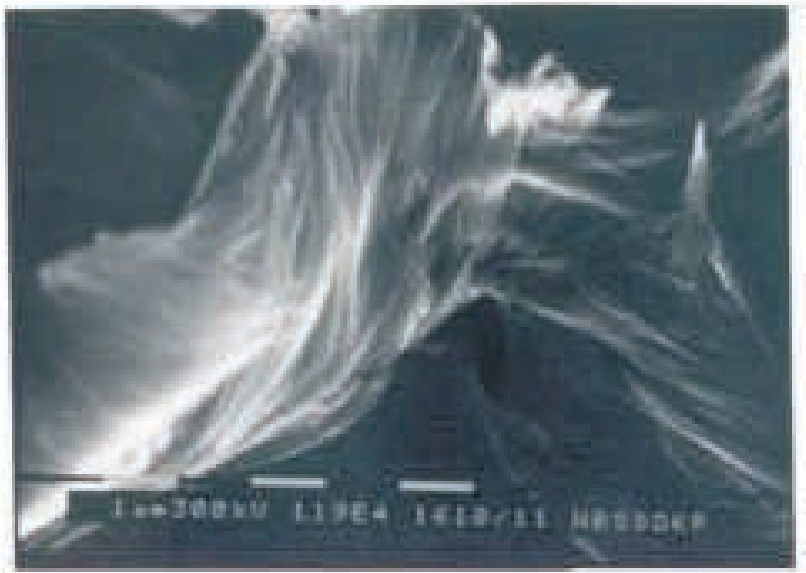

(d)

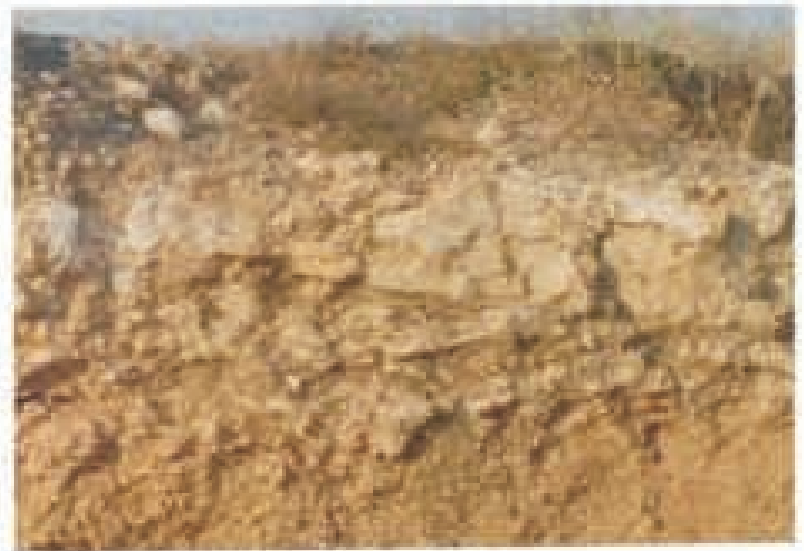

(f)

Plate 4. Plates 4(a) and 4(b) Photomicrograph of nodule of Unit III of Banar under polarised light (a) and under cathodoluminescence (b). Spar is generally non-luminescent whereas micritic groundmass is mostly dull orange luminescent; (c) Photomicrograph of lump from unit I showing spar cement in which the siliciclastic grains are only weakly floating (d) SEM photo of nodule from unit II showing bundle of palygorskite as a bridge between sand grains. Scale bar division $=1 \mu \mathrm{m}$; (e) Field view of Sunari Section. The exposed section is $\sim 3$ metres. The markings I, II and III are of the hardpans. Under each band is a separate nodular calcrete. The hardpans are warped; (f) Close-up of top hardpan (III). Note its break-up into prisms and blocks due to fracturing. 
Table 2. Electronmicroprobe analysis of nodule from Banar section.

\begin{tabular}{|c|c|c|c|c|c|c|c|}
\hline \multirow[b]{2}{*}{ Element } & \multicolumn{7}{|c|}{ Litho-unit III } \\
\hline & \multicolumn{2}{|c|}{ Whitish calcite } & \multicolumn{5}{|c|}{ Brown calcite } \\
\hline$\%$ & $\begin{array}{l}\text { Cluster } \\
1(12)\end{array}$ & $\begin{array}{c}\text { Cluster } 2 \\
(3)\end{array}$ & $\begin{array}{c}\text { Cluster } 1 \\
(5)\end{array}$ & $\begin{array}{c}\text { Cluster } 2 \\
(3)\end{array}$ & $\begin{array}{c}\text { Cluster } 3 \\
(3)\end{array}$ & $\begin{array}{c}\text { Cluster } 4 \\
(3)\end{array}$ & $\begin{array}{c}\text { Dark } \\
\text { dendrite }\end{array}$ \\
\hline $\mathrm{Na}$ & 0.03 & 0.15 & 0.10 & 0.13 & 0.36 & 0.06 & - \\
\hline $\mathrm{Fe}$ & - & 0.02 & 0.73 & 0.47 & 0.95 & 0.08 & 1.36 \\
\hline $\mathrm{Ca}$ & 53.18 & 52.08 & 48.40 & 45.71 & 25.30 & 3.92 & - \\
\hline $\mathrm{Mg}$ & 0.37 & 0.25 & 0.66 & 0.43 & 1.35 & 0.19 & 0.26 \\
\hline $\mathrm{Al}$ & 0.07 & 1.94 & 1.30 & 3.86 & 14.56 & 0.88 & 0.53 \\
\hline $\mathrm{Si}$ & 0.25 & 1.12 & 3.06 & 7.83 & 34.32 & 1.44 & 0.85 \\
\hline K & - & 0.02 & 0.10 & 0.37 & 1.36 & 0.96 & 0.19 \\
\hline $\mathrm{Ti}$ & - & - & 0.02 & 0.04 & 0.08 & - & - \\
\hline $\mathrm{Mn}$ & - & 0.13 & - & 0.03 & 0.05 & 0.03 & 48.6 \\
\hline $\mathrm{Sr}$ & 0.03 & 0.05 & 0.04 & 0.05 & 0.03 & - & 0.12 \\
\hline $\mathrm{Ba}$ & - & 0.04 & 0.01 & 0.03 & 0.08 & - & 0.63 \\
\hline $\mathrm{Zr}$ & - & - & - & - & - & - & - \\
\hline $\begin{array}{l}\mathrm{Ca} \text { as } \\
\mathrm{CaCO} 3\end{array}$ & 95.0 & 93.0 & 86.4 & 81.6 & 45.2 & 7.0 & - \\
\hline $\begin{array}{l}\text { Interpre- } \\
\text { tation }\end{array}$ & $\begin{array}{l}\text { Calcite } \\
\text { only }\end{array}$ & $\begin{array}{l}\text { Calcite with } \\
\text { traces of clay } \\
\text { and gibbsite }\end{array}$ & $\begin{array}{l}\text { Calcite with } \\
\text { minor clay } \\
\text { and } \mathrm{Fe}\end{array}$ & $\begin{array}{l}\text { Calcite with } \\
\text { some clay }\end{array}$ & $\begin{array}{l}\text { Clay- } \\
\text { calcite }\end{array}$ & $\begin{array}{l}\text { Organic } \\
\text { fragment }\end{array}$ & $\begin{array}{l}\text { Mainly } \\
\text { manganese } \\
\text { dioxide }\end{array}$ \\
\hline
\end{tabular}

Note: All values as oxides and as \% . Values in parenthesis are number of spots analysed.

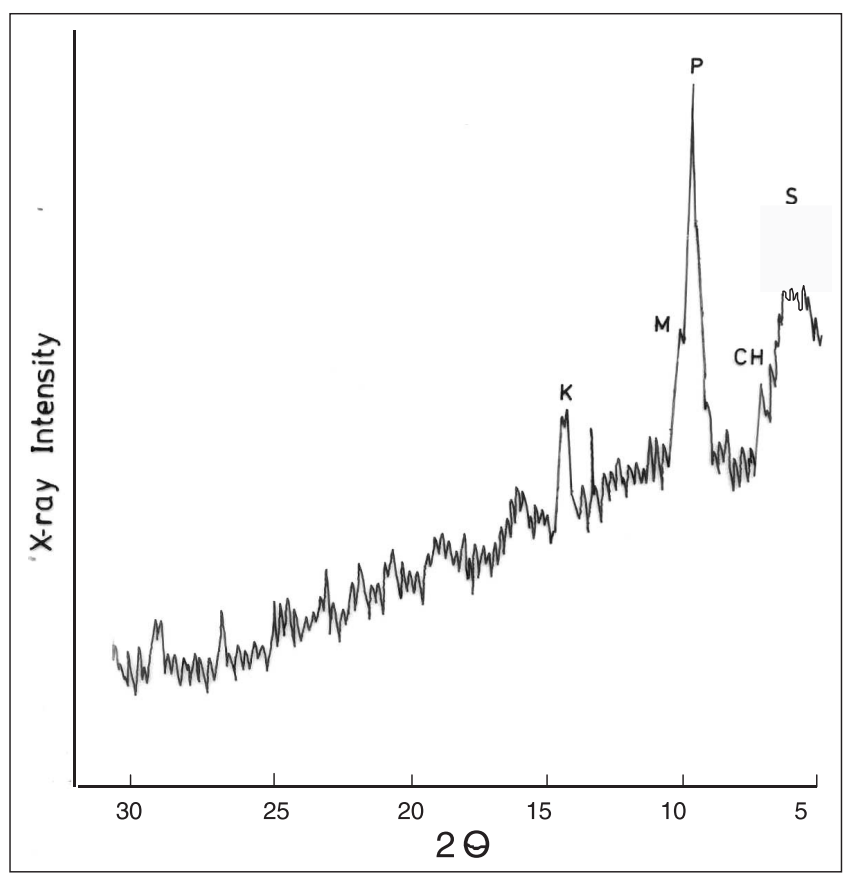

Figure 11. X-ray diffractogram of Ca-saturated, glycolated clay from nodule of unit II: $\mathbf{S}$-smectite, P-palygorskite, $\mathbf{M}$-mica and $\mathbf{K}$-kaolinite. The palygorskite peak is quite prominent, whereas that of smectite is ragged. Mica appears as a minor shoulder to the left of palygorskite. comprises a stack of calcretes but the distinguishing feature is the presence of hardpans developed over nodular calcretes (figure 12 and plate 4e). The upper most hardpan (III) is conspicuous, 10 to $60 \mathrm{~cm}$ thick, fairly persistent over tens of meters and is hard, compact, deformed, highly fractured into prisms and blocks with common dissolution cavities and channels. The lower boundary is sharp at places, and diffused at others, where it splits into fine bands (plate 4f). The middle hardpan is thin and is localized in its occurrence. The lowest hardpan (I) is prominent and deformed also, though fracturing is weak and dissolution cavities are nearly absent. Below the hardpans is a nodular calcrete. However, under hardpan I the nodule development is less prominent, and becomes chalky nodular/lumpy and finally grades into a poorly differentiated carbonate cemented stratum (figure 12). The nodules under the hardpan III and those under the hardpan I are dated to 350 and 650 ka respectively (table 4 ).

\subsubsection{Carbonate petrography}

The top hardpan (III) comprises mircrite-sparite groundmass, in which the siliciclastic grains are 
Table 3. Mineral composition of clay fraction (as per cent) in various litho-units of Banar section.

\begin{tabular}{lcccccc}
\hline \multicolumn{1}{c}{ Description } & Smectite & Palygorskite & Kaolinite & Mica & Chlorite & Vermi. - HIV \\
\hline IIIa soil $20 \mathrm{~cm}$ & 41 & 11 & 17 & 19 & 12 & $*$ \\
\hline IIIa soil $70 \mathrm{~cm}$ & 41 & 15 & 16 & 15 & 13 & $*$ \\
\hline $\begin{array}{l}\text { IIIb upper inter- } \\
\text { nodular soil. }\end{array}$ & 39 & 15 & 16 & 19 & 11 & $*$ \\
$\begin{array}{l}\text { IIIb upper } \\
\text { nodule }\end{array}$ & 31 & 25 & 16 & 15 & 13 & $*$ \\
\hline $\begin{array}{l}\text { IIIb lower inter- } \\
\text { nodular soil }\end{array}$ & 37 & 27 & 17 & 8 & 11 & $*$ \\
\hline $\begin{array}{l}\text { IIIb lower } \\
\text { nodular }\end{array}$ & 38 & 37 & 13 & 3 & 9 & $*$ \\
\hline \begin{tabular}{l} 
II inter-nod. \\
\hline II nodule
\end{tabular} & 43 & 37 & 10 & $*$ & 12 & $*$ \\
\hline \begin{tabular}{l} 
I lump \\
\hline
\end{tabular} & 26 & 54 & 8 & $*$ & 9 & $*$ \\
\hline
\end{tabular}

$*=$ Less than $5 \%$

$\mathrm{HIV}=$ Hydrated interlayerd vermiculite.

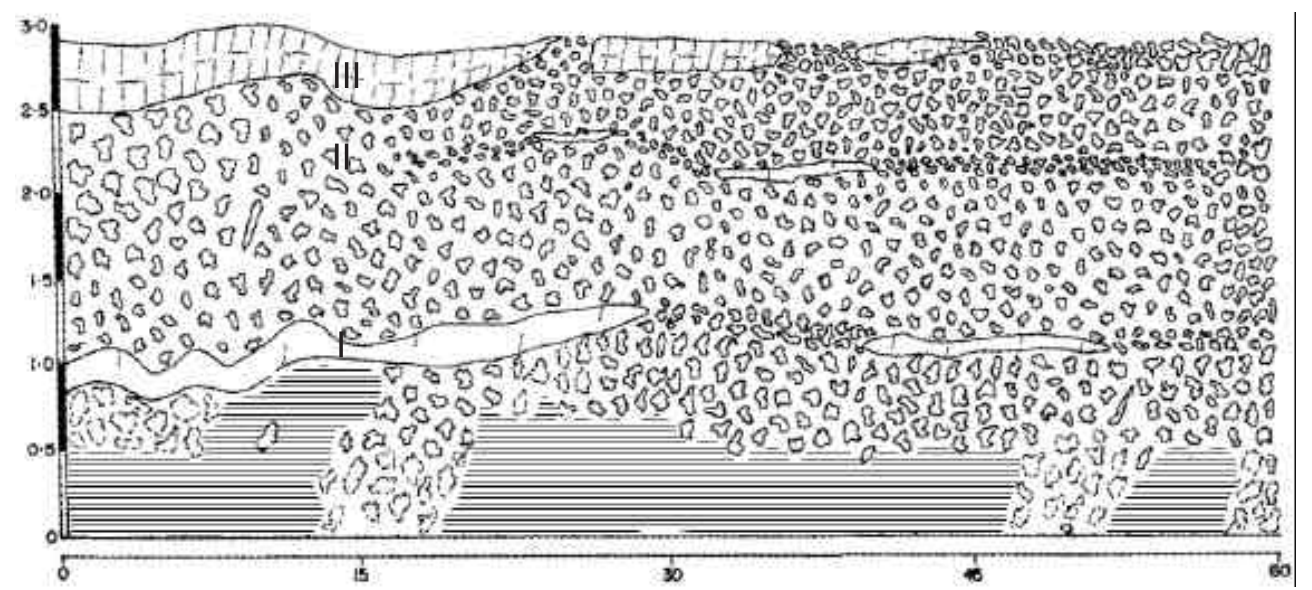

Figure 12. Sunari section in alluvial aggraded plain: It is an uncommon example of a hardpan calcrete over nodular calcrete. Equally significant are the prominent deformation structures. At the base is a cemented strata without differentiation into nodules. The calcrete under hardpan III and hardpan I are dated to 350 and 650 ka respectively.

widely dispersed. The grains as in the case of nodules show corona development (plate 5a). The macro-root related dissolutional channels have prominent micrite-spar lining with cavities filled by loose detritus The EPMA analysis shows that the groundmass is mainly calcite with traces of clay. The brecciated surfaces are extensively covered by laminae (plate 5b). Locally, the fragments of hardpan are enveloped by laminae. Analysis shows that the laminae comprise calcite with a minor amount of clay. The nodules underlying the hardpan are similar to those at Banar. Locally, clay-rich calcite is observed in the fringe area of the nodule. The nodules just above the hardpan I (lowest) show a calcitic groundmass, but locally dolomite-clay domains being replaced by calcite can be seen (plate 5c). The hardpan I itself comprises a uniform, light grayish groundmass in which, the siliciclastic grains are widely dispersed. EPMA data indicated that the groundmass is a dolomite-clay mixture. The groundmass is traversed by numerous cracks of various sizes resulting into a reticulate network (plate 5d). Evidence of spar filling up these cracks and penetrating the 
Table 4. Electron spin resonance dating results of sheetwash calcretes.

\begin{tabular}{lccc}
\hline \multicolumn{1}{c}{ Description of sample } & $\begin{array}{c}\text { Equivalent } \\
\text { Dose (Gy) }\end{array}$ & $\begin{array}{c}\text { Dose rate } \\
(\mathrm{Gy} / \mathrm{ka})\end{array}$ & Age (ka) \\
\hline Banar IIIb-Nodule & 105 & 0.92 & 114 \\
\hline Banar II-Nodule & 320 & 0.94 & 340 \\
\hline Osian 2III-Nodule & 170 & 1.05 & 162 \\
\hline Osian 2 II-Nodule & 300 & 1.08 & 278 \\
\hline Nandia Khurd V-Nodule & 260 & 1.06 & 245 \\
\hline Nandia Khurd VI-Nodule & 345 & 0.93 & 371 \\
\hline $\begin{array}{l}\text { Sunari-Nodule under } \\
\text { hardpan III }\end{array}$ & 350 & 1.00 & 350 \\
\hline $\begin{array}{l}\text { Sunari-Nodule under } \\
\text { hardpan I }\end{array}$ & 650 & 1.00 & 650 \\
\hline
\end{tabular}

dolomite-clay groundmass is seen (plate 5e). The chalky nodules/lumps and the undifferentiated, cemented stratum underneath comprise dolomiteclay mixture with some sand-sized clastic grains.

The Sunari section posseses several distinctive features compared to other calcretes. It shows the presence of a series of hardpans, of which the one at the top is fairly persistent. Though it occurs as a continuous carbonate horizon (Stage III of Machette 1985), it is not a plugged horizon that developed by further carbonate enrichment of a pre-existing calcrete hardpan. It underwent warping during its ductile phase, due to the volume change in the underlying strata. Brecciation and deposition of laminae on the brecciated surface was a subsequent development. Another distinguishing feature is the calcite-dolomite distribution. The upper half of the section is almost entirely calcitic. Thereafter, dolomite starts showing its presence; the carbonate in hardpan (I) and the underlying calcrete being almost entirely dolomite.

\subsection{Stable isotope data on sheetwash aggraded plain calcretes}

Several nodules from the same calcrete and subfractions of individual nodules based on the position and discernible variations were micro-drilled and analysed. The results are presented in table 5 . In the case of Banar, $\delta^{13} \mathrm{C}$ values of all the three calcretes and their sub-samples lie in a narrow range of -0.4 to $1.2 \%$. The values in the interior part of the nodule are similar to those of the fringe area or the cavity spar in a nodule. Though a tendency is there for the values to become more positive from calcrete (I) upwards, the difference is minor. The values from Nandia Khurd and Osian-I sections are also in the same range. In the Sunari section, both the hardpans and the nodules show more positive values with a mean value of $1.1 \%$. The values remain typical of those from $\mathrm{C} 4$ vegetation type.

In comparison to the carbon isotope, the $\delta^{18} \mathrm{O}$ values show a broader range of values. In Banar the values range from -2.7 to $-6.3 \%$ with a mean value of $-4.4 \%$. Interestingly, the interior of the nodules has more negative values than the peripheral part or the cavity spar in a nodule. Thus the latter appear to have developed from solution with more evaporated water than the interior of the nodule. The range of isotope values in the three calcretes in the stack is about the same. The Osian and Sunari samples have similar values but Nandia Khurd posseses generally more negative values. Overall, it seems that the calcretes developed in slightly less evaporated meteoric waters, though the peripheral part of the nodule and neospar precipitation was from solutions with more evaporated water. The correlation between $\delta^{13} \mathrm{C}$ and $\delta^{18} \mathrm{O}$ values was poor in all the calcretes, being 0.22 for Banar and 0.08 for Nandia Khurd.

\section{Inferences}

The four sections, of which two have been described in detail, show several common features that permit the following inferences:

- Multiple calcrete sequence: The 3-5 meter thick column of calcrete comprises a number of calcretes placed one above the other, each about a meter in thickness. Individual calcretes in a stack differ from each other in frequency and/or size of nodules, and the boundaries are distinct. Further, a zone of millimeter sized, rounded 


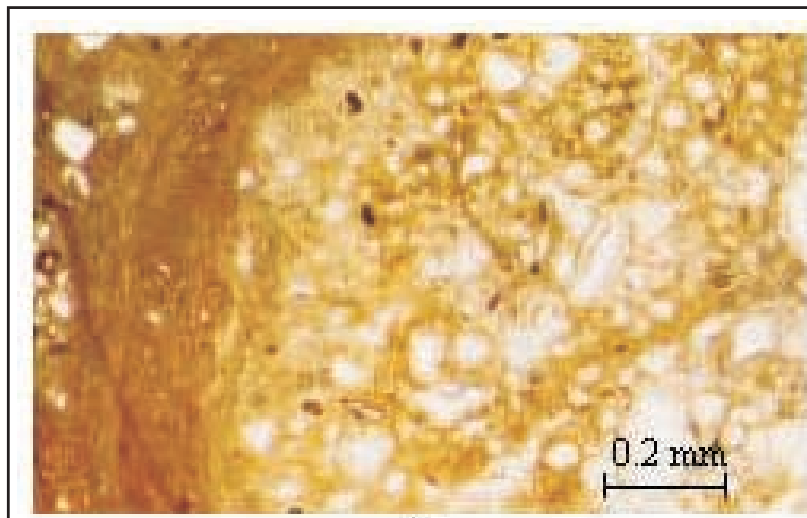

(a)

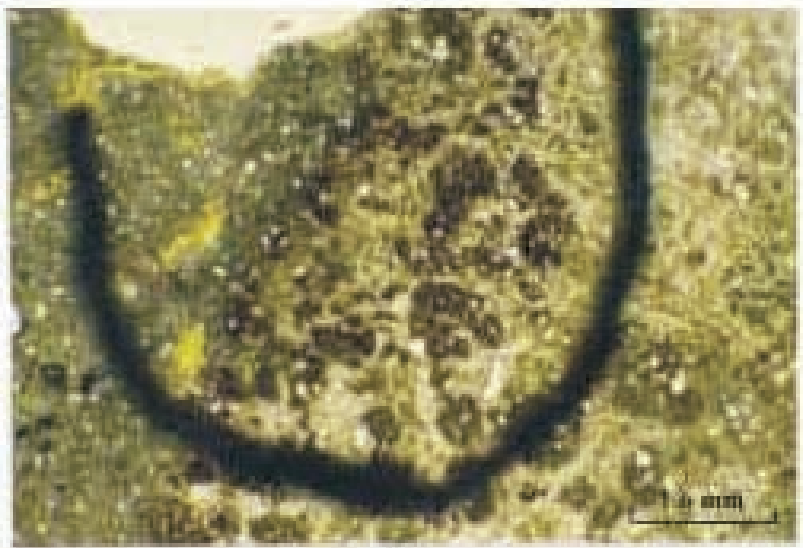

(c)

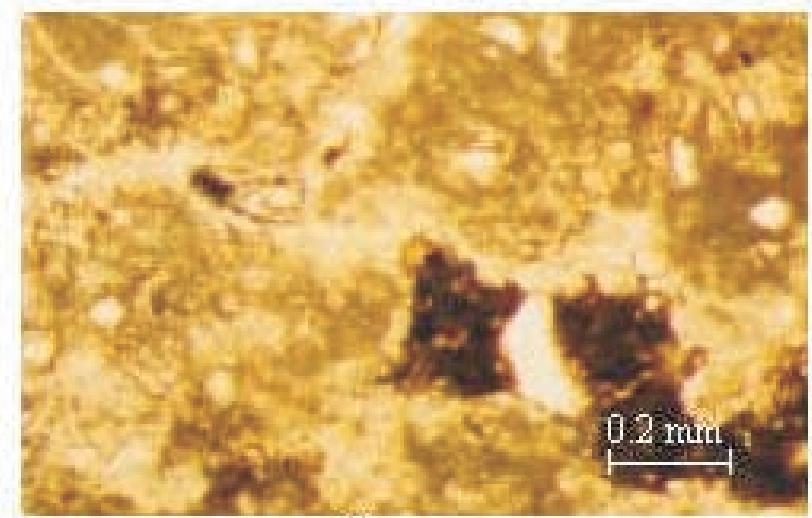

(e)

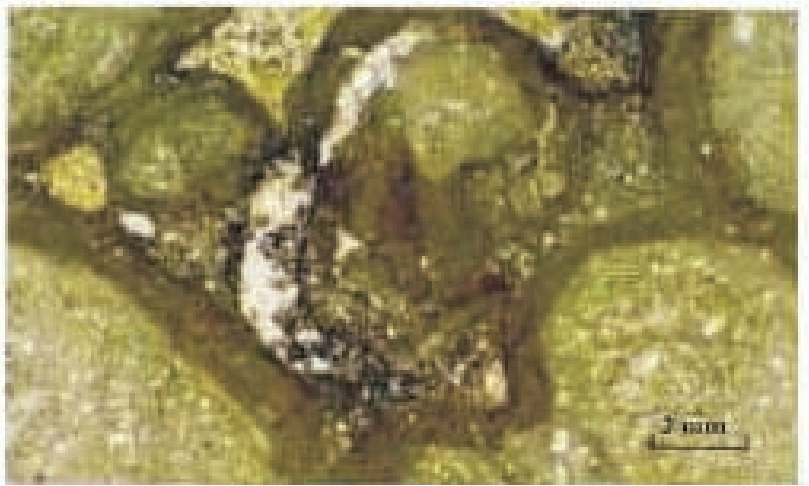

(b)

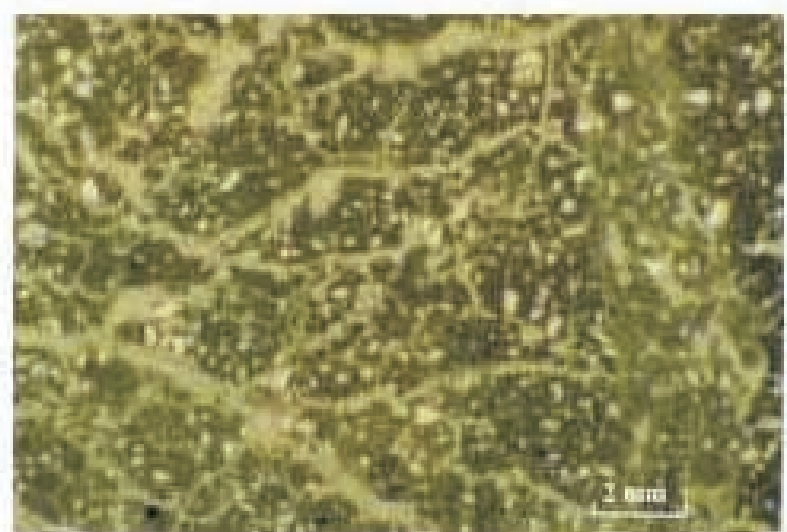

(d)

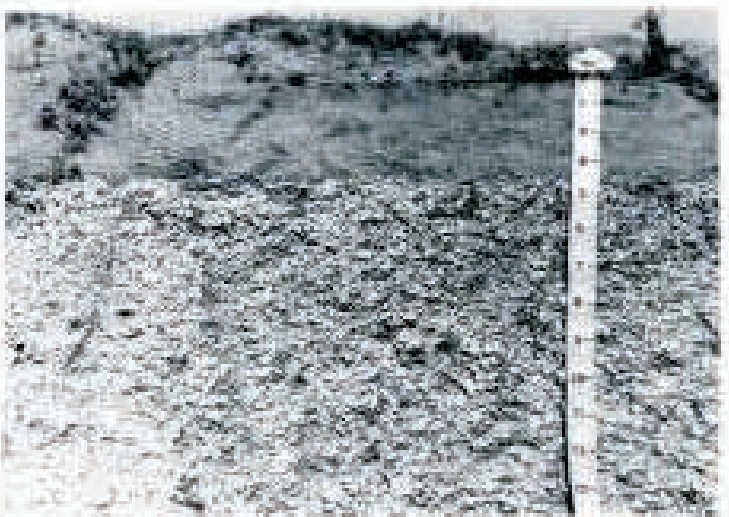

(f)

Plate 5. (a) Photomicrograph of hardpan III. The organisation is similar to that of a nodule. To the left is a subsequent laminar growth: (b) Photomicrograph of the upper part of hardpan showing prominent laminar growth around brecciated surface. The lamina are mainly calcite with traces of clay; (c) Photomicrograph of nodule under hardpan II. Like nodules elsewhere the groundmass is calcitic. Locally, remnants of dark brown clay-dolomite host are seen in process of replacement by calcite. The dark circular mark is of ink: (d) Photomicrograph of hardpan I. Note the reticulate pattern of fine and very fine shrinkage cracks, partially filled by carbonate. The brownish groundmass is clay-rich dolomite: (e) Close-up of 'd' showing spar-filled cracks. Also seen is progressive replacement of clay-dolomite host by spar in the immediate vicinity of cracks; (f) Calcretes in sheetwash aggraded plains invariably have an abrupt, planar (horizontal) boundary, which is persistent over considerable distances and is considered one of the evidences in support of carbonate enrichment from groundwater. 
Table 5. Stable isotope results of sheetwash aggraded plain calcretes.

\begin{tabular}{|c|c|c|c|c|c|}
\hline Sample description & $\delta^{13} \mathrm{C}(\%)$ & $\delta^{18} \mathrm{O}(\%)$ & Sample description & $\delta^{13} \mathrm{C}(\%)$ & $\delta^{18} \mathrm{O}(\%)$ \\
\hline Banar section & & & Nandia Khurd sectior & & \\
\hline III b upper nodule core & 1.2 & -5.0 & $\mathrm{~V}$ nodule core & 0.1 & -5.7 \\
\hline III b upper nodule outer & 1.1 & -2.7 & $\mathrm{~V}$ nodule mottle & -0.1 & -5.8 \\
\hline III b upper nodule cavity fill & 1.2 & -3.8 & IV nodule core & 0.4 & -5.4 \\
\hline III b lower nodule core & 0.6 & -5.1 & IV nodule outer & 0.2 & -4.8 \\
\hline III b lower nodule outer & 1.0 & -3.5 & IV nodule mottle & 0 & -5.0 \\
\hline II nodule core & 0.1 & -5.2 & III nodule core & 0.1 & -5.5 \\
\hline II nodule outer & -0.4 & -5.1 & III nodule mottle & 0 & -5.2 \\
\hline II nodule periphery & 1.0 & -6.3 & II upper nodule core & 0 & -5.3 \\
\hline II nodule mottle & 0.3 & -4.2 & II lower nodule core & -0.5 & -5.7 \\
\hline I lump interior & 0.3 & -4.4 & II nodule mottle & 0.8 & -6.4 \\
\hline I lump outer & 1.1 & -3.7 & I upper lump middle & -0.3 & -4.8 \\
\hline I nodule & -0.3 & -4.4 & I upper outer & -0.4 & -4.7 \\
\hline I rhizocretion core & 0 & -4.4 & I lower middle & -1.1 & -6.6 \\
\hline I rhizocretion core & 0 & -4.0 & I lower outer & -1.1 & -5.4 \\
\hline I rhizocretion outer & 0.8 & -3.5 & & & \\
\hline Mean & 0.6 & -4.7 & Mean & -0.2 & -5.4 \\
\hline Standard deviation & 0.6 & 1.0 & Standard deviation & 0.5 & 0.1 \\
\hline Sunari section & & & Osian-I section & & \\
\hline Hardpan III & 1.6 & -3.2 & III nodule core & 1.0 & -3.6 \\
\hline Nodule under hardpan II & 0.9 & -5.9 & III nodule mottle & 0.7 & -5.6 \\
\hline Hardpan I & -0.3 & -5.1 & II nodule core & 1.0 & -3.6 \\
\hline Nodule under hardpan I & 2.1 & -3.4 & I upper nodule core & 0.6 & -4.7 \\
\hline Lump under hardpan I & 1.1 & -4.2 & I upper nodule outer & 0.8 & -4.9 \\
\hline \multirow[t]{4}{*}{ Strata under hardpan } & 1.0 & -3.8 & I middle nodule core & -0.1 & -5.6 \\
\hline & & & I middle nodule outer & 0.6 & -4.7 \\
\hline & & & I lower nodule core & 0.9 & -5.7 \\
\hline & & & I lower nodule outer & 0.7 & -5.3 \\
\hline
\end{tabular}

nodules, interpreted as transported clasts, usually forms the base of an individual calcrete. In Banar, Osian-I and Sunari, where it has been possible to map and log continuously over hundreds of meters, the calcretes are laterally persistent. Thus, it seems that the individual calcretes are independent entities. The identified calcrete units not only show a progressive decrease in age upsection but also that the age differences between successive calcretes is of the order of a few hundred thousand years e.g., $114 \mathrm{ka}$ (Unit III) and $340 \mathrm{ka}$ (Unit II) at Banar or $162 \mathrm{ka}$ (Unit III) and $278 \mathrm{ka}$ (Unit II) of Osian-I sec- tions (table 4). Thus, the stack has developed by an individual aggradation followed by calcrete development therein; a hiatus on timescales of hundred thousand years and emplacement of another aggradation followed by calcrete development therein. The results in table 4 show that the calcretes in sheetwash aggraded plains lie in mid- Pleistocene.

- Carbonate stock: The calcretes (nodules and the inter-nodular material) contain $40-60 \%$ by weight of calcium carbonate. Regional studies have shown that the calcretes are common as a near surface formation in sheetwash aggraded 
Table 6. Brief description of other ancient calcretes.

\begin{tabular}{|c|c|c|c|c|}
\hline Location & $\begin{array}{l}\text { Host and } \\
\text { occurrence }\end{array}$ & Log description & $\begin{array}{l}\text { Sample } \\
\text { dated }\end{array}$ & Age (ka) \\
\hline $\begin{array}{l}\text { Sarari } \\
\left(74^{\circ} 32^{\prime} ; 27^{\circ} 33^{\prime}\right)\end{array}$ & $\begin{array}{l}\text { Amphibolite } \\
\text { schist outcrop }\end{array}$ & $\begin{array}{l}0.75 \mathrm{~m} \text { section exposing a } \\
\text { massive calcrete duricrust in } \\
\text { host rock. Quartz vein shows } \\
\text { partial replacement }\end{array}$ & NA & Not dated \\
\hline $\begin{array}{l}\text { Lalasari } \\
\left(74^{\circ} 42^{\prime} ; 27^{\circ} 29^{\prime}\right)\end{array}$ & $\begin{array}{l}\text { Chlorite schist } \\
\text { outcrop }\end{array}$ & $\begin{array}{l}1.5 \mathrm{~m} \text { section exposing a } \\
\text { massive calcrete duricrust in } \\
\text { host rock }\end{array}$ & NA & Not dated \\
\hline $\begin{array}{l}\text { Dhurila } \\
\left(74^{\circ} 20^{\prime} ; 27^{\circ} 23^{\prime}\right)\end{array}$ & $\begin{array}{l}\text { Buried pediment } \\
\text { in siliceous lime- } \\
\text { stone }\end{array}$ & $\begin{array}{l}2.5 \mathrm{~m} \text { section; } 0.5 \mathrm{~m} \text { boulder } \\
\text { calcrete and then nodular } \\
\text { calcrete }\end{array}$ & Nodule & 1143 \\
\hline $\begin{array}{l}\text { Katoti } \\
\left(74^{\circ} 32^{\prime} ; 27^{\circ} 33^{\prime}\right)\end{array}$ & $\begin{array}{l}\text { Colluvio-alluvial } \\
\text { plain. Clasts are } \\
\text { polymictic }\end{array}$ & $\begin{array}{l}2 \mathrm{~m} \text { exposure. } \sim 1 \mathrm{~m} \text { brec- } \\
\text { ciated hardpan followed by } \\
\text { nodular calcrete, hardpan } \\
\text { has pisolites and peloids, } \\
\text { both in younger cement and } \\
\text { patchy laminar calcrete at } \\
\text { the top (Plate } 8 \mathrm{~d} \text { ) }\end{array}$ & $\begin{array}{l}\text { Hardpan-Red } \\
\text { ground mass; } \\
\text { Light red infill }\end{array}$ & $1542-840$ \\
\hline $\begin{array}{l}\text { Ratau } \\
\left(74^{\circ} 21^{\prime} ; 27^{\circ} 26^{\prime}\right)\end{array}$ & $\begin{array}{l}\text { Colluvio-alluvial } \\
\text { plain. Clasts are } \\
\text { polymictic }\end{array}$ & $\begin{array}{l}3 \mathrm{~m} \text { exposure showing a } \\
\text { stack. A } 0.8 \text { nodular calcrete } \\
\text { at top, followed by a } 0.5 \mathrm{~m} \\
\text { brecciated hardpan and then } \\
\text { a thick nodular calcrete }\end{array}$ & $\begin{array}{l}\text { Nodule from } \\
\text { lower calcrete }\end{array}$ & 985 \\
\hline $\begin{array}{l}\text { Nimbli Jodhan } \\
\left(74^{\circ} 21^{\prime} ; 27^{\circ} 32^{\prime}\right)\end{array}$ & $\begin{array}{l}\text { Colluvio-alluvial } \\
\text { plain. Clasts are } \\
\text { polymictic }\end{array}$ & $\begin{array}{l}5 \mathrm{~m} \text { section with a stack of } \\
\text { three calcretes. The middle } \\
\text { calcrete has a patchy hard- } \\
\text { pan at the top. }\end{array}$ & $\begin{array}{l}\text { Nodule from } \\
\text { lower calcrete }\end{array}$ & 950 \\
\hline $\begin{array}{l}\text { Dab } \\
\left(74^{\circ} 25^{\prime} ; 27^{\circ} 32^{\prime}\right)\end{array}$ & $\begin{array}{l}\text { Colluvio-alluvial } \\
\text { plain. Clasts are } \\
\text { polymictic, iso- } \\
\text { lated remnant }\end{array}$ & $\begin{array}{l}2 \mathrm{~m} \text { exposure. } 0.8 \mathrm{~m} \text { brec- } \\
\text { ciated hardpan, followed by } \\
\text { nodular calcrete }\end{array}$ & NA & Not dated \\
\hline $\begin{array}{l}\text { Badela } \\
\left(74^{\circ} 22^{\prime} ; 27^{\circ} 32^{\prime}\right)\end{array}$ & $\begin{array}{l}\text { Colluvio-alluvial } \\
\text { plain. Remnant } \\
\text { as a mound }\end{array}$ & $\begin{array}{l}2 \mathrm{~m} \text { exposure with a stack of } \\
\text { two nodular calcretes. }\end{array}$ & $\begin{array}{l}\text { Nodule from } \\
\text { upper calcrete }\end{array}$ & 560 \\
\hline $\begin{array}{l}\text { Chandrok } \\
\left(74^{\circ} 42^{\prime} ; 27^{\circ} 29^{\prime}\right)\end{array}$ & $\begin{array}{l}\text { Sheetwash } \\
\text { aggraded plain. } \\
\text { Remnant as a } \\
\text { mound.Truncated. }\end{array}$ & $\begin{array}{l}2 \mathrm{~m} \text { exposure. Patchy boul- } \\
\text { der calcrete with lag in top } \\
50 \mathrm{~cm} \text { and nodular calcrete } \\
\text { underneath. }\end{array}$ & Nodule & 1018 \\
\hline $\begin{array}{l}\text { Lordian } \\
\left(74^{\circ} 28^{\prime} ; 27^{\circ} 03^{\prime}\right)\end{array}$ & $\begin{array}{l}\text { Pediment rem- } \\
\text { nant. Truncated }\end{array}$ & $\begin{array}{l}1 \mathrm{~m} \text { exposure. Patchy boul- } \\
\text { der calcrete underlain by } \\
\text { nodular calcrete }\end{array}$ & $\begin{array}{l}\text { Nodule under } \\
\text { hardpan }\end{array}$ & 1027 \\
\hline $\begin{array}{l}\text { Badgaon } \\
\left(71^{\circ} 11^{\prime} ; 26^{\circ} 49^{\prime}\right)\end{array}$ & $\begin{array}{l}\text { Colluvio-alluvial } \\
\text { plain }\end{array}$ & $\begin{array}{l}2.5 \mathrm{~m} \text { exposure shows a stack } \\
\text { of two calcretes }\end{array}$ & $\begin{array}{l}\text { Nodule from } \\
\text { upper calcrete }\end{array}$ & 686 \\
\hline
\end{tabular}

plains; although with variation in the strength of development. Thus, a large amount of carbonate is held in the landscape. There are no calcareous rocks in the vicinity that could have acted as a source. Several of the calcretes have transported nodules at the base, which allude to pre-existing calcretes in proximal regions. Hence, some amount of calcareousness can be attributed to the host itself. Further, the individual calcretes often have an abrupt, planar boundary that maintains a perfect level across several hundred meters distance (Plate 5f). This is indicative of a groundwater contribution also.

- Nodularity and diagenesis: Hard, dense, disorthic nodules of $1-10 \mathrm{~cm}$ size are a striking feature of the calcretes. Though such a pronounced nodularity has been shown in the calcretes from southern Africa (Netterberg 1969; Watts 1980), calcretes elsewhere do not show such prominent nodule development. The nodules are spheroidal 
to ellpsoidal and possess a smooth surface. At a first look the sphericity and roundness of the nodules gives an impression of these being transported features in the host material. But this is not so. The nodule bearing strata lack any bedding planes characteristic of a sedimentary deposit. Further, if such large clasts were indeed transported, then clasts of comparable size from the rock outcrops that exist in the vicinity should have been present with the nodules. This is not the case. The low relief of the terrain precludes a transport competency for such large size nodules on a landscape scale. Finally, nodules of varying size occur at random in the same calcrete mass. The arguments clearly support an in situ growth of nodules.

Thin sections of nodules show some reorganization of the micritic-microsparitic groundmass. Besides, there are shrinkage cavities and cracks, often filled or lined by younger sparite growths and corona around sand grains. The presence of clay-micrite mixtures, degradation products of siliciclastic grains (particularly clays) as revealed by EPMA studies, suggest that nodule development is not a simple, physical process of carbonate precipitation, but that it involves several precipitation and dissolution episodes accompanied by some degradation of host silicate minerals. Since palygorskite is only a minor constituent in the host sediments, its extraordinary presence in calcretes suggests its diagenetic origin.

- Paleoenvironments: The stable carbon isotope data suggest a typical $\mathrm{C} 4$ vegetation ecosystem in which the calcretes formed. However, range in $\delta^{18} \mathrm{O}$ values indicates that the solutions from which the carbonate precipitated were generally comprised of only slightly evaporated meteoric water.

- Dissolutional degradation: The nodules show smooth surfaces with dissolution cavities. Some of these acquire even a knobby, mammilated appearance because of localized dissolution. Original coalescences of nodules show perforations. The inter-nodular earthy matter between nodules in the upper part of the calcrete is less calcareous and shows progressive increase in carbonate with depth; the latter possesses young carbonate accumulation in the form of poorlydefined segregations. Thus it seems, that after their formation, the calcretes have undergone dissolutional degradation.

\section{Calcretes in regolith}

In places, calcretes occur in regoliths of bedrock such as sandstone, granite, gneiss and schist.
Such calcretes show variable maturity including some simple morphologies comparable to those of sheetwash aggraded plains. Numerous sandstone quarries in the area show penetration of carbonate through fractures and joints. An advanced disintegration of host sandstone and calcrete development is seen in the Ratanada section $\left(72^{\circ} 28^{\prime} 16^{\prime \prime} \mathrm{E} ; 26^{\circ} 42^{\prime} 13^{\prime \prime} \mathrm{N}\right)$, (plate 6a). The indurated sandstone has been observed to disintegrate into smaller fragments and then into a regolith with a nodular calcrete therein. A section with thicker regolith and calcrete is described below.

The Anwana-Binja section $\left(73^{\circ} 09^{\prime} 53^{\prime \prime} \mathrm{E}\right.$; $\left.26^{\circ} 40^{\prime} 26^{\prime \prime} \mathrm{N}\right)$ is 6 meters deep with the upper 1.5 meters consisting of aeolian sandsheet with reworked nodules. The lower 4.5-meter is in situ formed calcrete in regolith of sandstone of Sonia Formation of the Jodhpur Group (plate 6b). The major part is made up of nodular calcrete, which at the base becomes gradually lumpy. The carbonate content is uniform at about $40 \%$ of the total mass, and a major part of this mass occurs as nodules or lumps. The inter-nodular material is dominated by sand with a small amount of clay and silt. The sand fractions show an increase in finer fractions with corresponding decrease in coarser fractions upwards from the base.

At the bottom of the section, the lumpy forms show a largely micritic groundmass with closely spaced siliciclastic grains. Nodules in the overlying solum with predominant micrite-sparite groundmass show besides corona devlopment, locally intergrown spar and formation of clay-micrite patches such as have been described for nodules developed in the sheetwash aggraded plains. Clay mineral analysis shows a predominance of palygorskite in the upper part with a corresponding decrease of mica and smectite, and a near absence of chlorite. We consider that the mode of carbonate enrichment and the process of nodule formation are similar to those of sheetwash calcretes.

\subsection{Calcretes in other regoliths}

Thick weathering zones with calcrete development were also observed in granite in widely scattered locations. The basal part, generally $2-3$ meter thick is made up of grus with a massive cementation by carbonate. Differentiation into segregated forms here is poor. Upwards, nodules become progressively prominent in a thickness of 1 to 2 meters. Quartzites show very thin regolith and a variable calcrete development. Limestone outcrops generally have a half to a meter gravelly to cobbly, regolith; and features attributable to secondary carbonate are few. The schists and gneisses around 


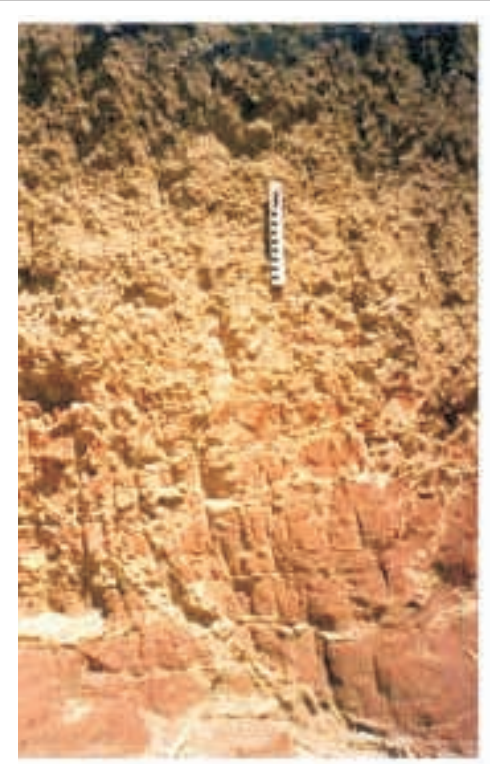

(a)

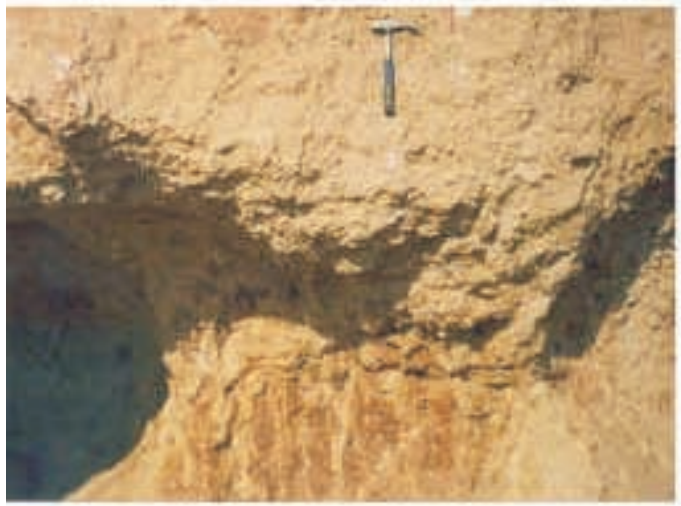

(c)

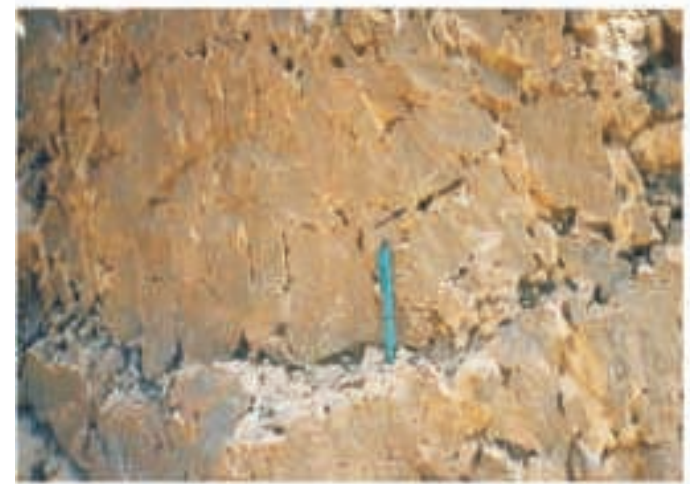

(e)

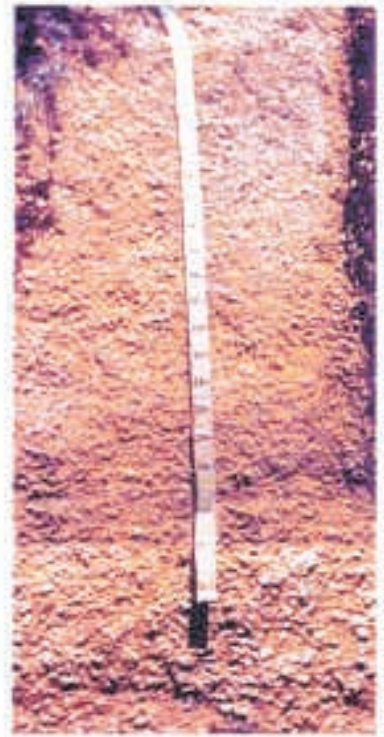

(b)

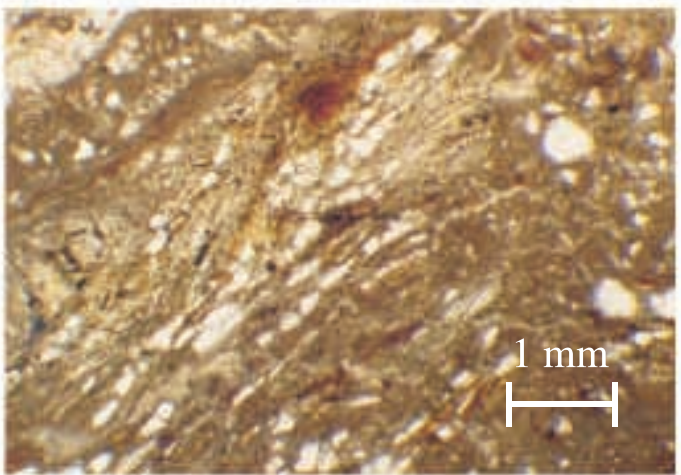

(d)

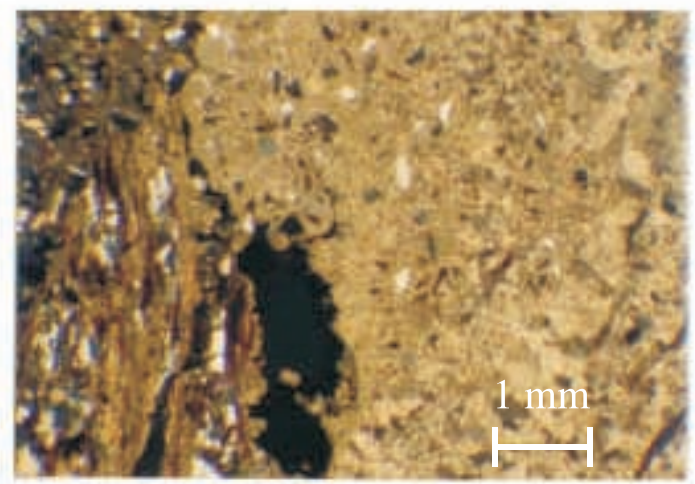

(f)

Plate 6. (a) Field view of calcrete in regolith of sandstone at Ratanada. Note the change from the rather fresh rock to highly fragmented regolith and a nodular calcrete therein; (b) View of 4-meter deep Anwana-Binja Section in regolith of sandstone and the nodular calcrete therein. The horizontal boundary at the base is a watermark; (c) View of Ringan Section, showing in the basal part the regolith of mica schist, locally penetrated by carbonate. The exposure is $\sim 3$ meters deep; (d) Photomicrograph of regolith showing exfoliation of mica bundle by carbonate impregnation; (e) Field view of massive, reddish calcrete with vertically oriented fabric. It is interpreted to have developed directly from replacement of host mica schist; (f) Photomicrograph of the massive calcrete showing micrite and anhedral spar-dominated groundmass. Also seen is a rare remnant of host rock. 
Sambhar-Phulera region also have well-developed calcretes.

\section{Ancient calcretes}

As discussed in the section on calcrete occurrences, the use of the term "ancient" calcretes was made in view of their evolved morphologies and a generally truncated or dismantled appearance. Often, ancient calcretes occur as isolated features with a positive relief amidst younger landforms. Several sections were examined, of which two are described in detail and a brief description of others appears in table 6 . The field logs of calcretes developed in regolith do not conform to the standard lithounit divisions as in the case of calcretes developed in aeolian or sheetwash aggraded plain. Therefore, these have been described as facies.

\subsection{Ringan section}

This section $\left(74^{\circ} 40^{\prime} 18^{\prime \prime} \mathrm{E} ; 27^{\circ} 35^{\prime} 39^{\prime \prime} \mathrm{N}\right)$ is located halfway on the road between Mithri and Ringan villages in a quarry $(\sim 350 \times 250 \mathrm{~m})$ with an exposed depth of 2.5 to 3 meters. The section lies under a veneer of aeolian sand and comprises mature calcrete developed in a regolith of mica schist of the Delhi Supergroup. The host rock with vertically disposed schistosity is exposed at several places at the base of the section. The calcrete comprises several facies (figure 13). Individual facies are laterally impersistent and even the dominant nodular facies is only occasionally and weakly expressed in a part of this large quarry.

The regolith facies comprises very dark yellowish brown earthy matter with partially weathered fragments of mica schist. Conspicuous carbonate infillings are seen parallel to the schistosity of the host rock (plate 6c). Thin sections (plate 6d) show exfoliation of schist fragments due to impregnation by carbonate. Locally, the schistosity is obliterated. The nodules constitute $\sim 35$ to $85 \%$, and are highly calcareous, with a carbonate content of 70 to $95 \%$. In the lower part of the section, calcretes are chalky to hard but in the middle and upper parts, these are invariably hard. The internal fabric of hard nodules is complex. The groundmass is dominated by micrite, which locally has evolved into microspar. The light coloured calcite mass grades into dark brown domains, which the EPMA data showed to be calcite-clay mixture. Locally, gibbsite or cryptocrystalline silica are also present. There are shrinkage cracks filled with spar.

An interesting feature is the development of a hard, reddish, massive calcrete facies (plate 6e).
In outcrop, a faint schistosity resembling the original rock structure is seen. Occasionally, partially weathered host-rock fragments are present. There is some evidence that this facies originated directly from the host rock without a transitional regolith stage as in the case of Anwana-Binja section described earlier. Vertically oriented solution cavities and channels are common and at few places, cross cutting channels thickly lined with younger carbonate are observed (clearly a later event). In thin sections (plate $6 \mathrm{f}$ ) the calcrete comprises a spar or micrite groundmass with few fragments of host rock. EPMA results show that the spar is entirely calcite, whereas the micrite has some amount of silicate clay with local occurrences of free silica, iron oxide or gibbsite. Thus, during formation of the calcrete, much of the original constituents of the host rock were replaced. In places, this facies is extensively fractured and the open space is filled with younger carbonate. The calcrete has been ESR dated to $\sim 1200 \mathrm{ka}$ (table 9 ).

Hardpan facies is often 30 to $60 \mathrm{~cm}$ thick and impersistent (plate 7a). The hardpan has vertical and sheet fractures. In thin section, it comprises tightly packed light brown, micritic groundmass with common siliciclastic grains. Occasionally, nodules are also present (plate $7 \mathrm{~b}$ ). The nodules have a micrite-clay envelope. The fractured surface is lined by thick clay-micrite lamina. The groundmass is locally traversed by solution and shrinkage cavities with zoned calcite infill (plate 7c). Occasionally, vein quartz grains are present. These are often exploded with spar filling up the open space. From the organisation of the features, the developmental sequence can be inferred as follows:

- regolith of host rock,

- development of a weak nodular calcrete,

- carbonate-rich aggradation,

- its consolidation into a hardpan,

- extensive fracturing and deposition of lamina on fractured surfaces and shrinkage features

- extensive dissolutional degradation and filling up of cavities with detritus and carbonate); second stage of consolidation

- current dissolutional degradation; the original hardpan has an ESR age of $\sim 800 \mathrm{ka}$.

It is surmised that calcrete development occurred in the regolith/bedrock of mica schists. The host rock is not abundant in calcium and therefore the large mass of calcium carbonate in the calcrete has to be externally sourced. Unlike calcretes in sheetwash plains, the total carbonate content is spatially variable. Calcretes with vertically oriented fabric are a case where the host rock has been completely replaced, except the most resistant quartz fragments. 
Table 7. Description of various lithounits of Anwana section.

\begin{tabular}{|c|c|}
\hline $\begin{array}{l}\text { Unit VIII } \\
\text { Brecciated hardpan } \\
\text { calcrete }\end{array}$ & $\begin{array}{l}\text { The unit has an exposed thickness of } 4 \mathrm{~m} \text { and shows many different calcretes like } \\
\text { the laminar and pisolitic calcretes besides the light grey colour cement, which fills } \\
\text { brecciated cracks. At several places the cracks and vughs are filled with nodules, at } \\
\text { places clustered into botryoidal form. The light coloured carbonate cementing the } \\
\text { nodules is rich in detritus. The upper } 30-35 \mathrm{~cm} \text { stratum has dissolution channels and } \\
\text { vughs filled with pisolites. Laminar calcrete is thin and patchy. }\end{array}$ \\
\hline $\begin{array}{l}\text { Unit VII } \\
\text { Chalky calcrete }\end{array}$ & $\begin{array}{l}\text { The unit is } 50 \mathrm{~cm} \text { thick with sharp upper and lower contacts, is made up of deep red } \\
\text { fragmented chert. Besides the vertical cracks, the disruption along bedding plane is } \\
\text { also conspicuous. The fractures are filled with light grey to white powder calcrete } \\
\text { with slight induration. }\end{array}$ \\
\hline $\begin{array}{l}\text { Unit VI } \\
\text { Massive calcrete }\end{array}$ & $\begin{array}{l}\text { The unit, } 45-50 \mathrm{~cm} \text { thick with sharp upper and lower contacts, is made up of deep red } \\
\text { fragmented chert. Besides the vertical cracks, the disruption along bedding planes is } \\
\text { also conspicuous. The fractures are filled with light grey to white powdery calcrete } \\
\text { with slight induration. }\end{array}$ \\
\hline $\begin{array}{l}\text { Unit V } \\
\text { Box-work calcrete }\end{array}$ & $\begin{array}{l}\text { This unit is } 10-25 \mathrm{~cm} \text { thick. It is distinguished by a rectangular lattice framework. } \\
\text { The network is made up of veins of calcite with variously coloured clays in between. }\end{array}$ \\
\hline $\begin{array}{l}\text { Unit IV } \\
\text { Massive calcrete }\end{array}$ & $\begin{array}{l}\text { It is white to buff colour, fine grained and hard, massive calcrete with chert fragments } \\
\text { forming boudin structures. }\end{array}$ \\
\hline $\begin{array}{l}\text { Unit III } \\
\text { Massive calcrete }\end{array}$ & $\begin{array}{l}\text { The unit consists of calcrete and pink host sandstone. It shows a large number of } \\
\text { deformation features like medium to minor scale folds, shears and slip planes. }\end{array}$ \\
\hline $\begin{array}{l}\text { Unit II } \\
\text { Indurated, massive } \\
\text { calcrete }\end{array}$ & $\begin{array}{l}\text { The upper part of this unit has a thin boxwork calcrete similar to unit } \mathrm{V} \text { above. The } \\
\text { lower part is buff coloured, hard, massive fine-grained calcrete with fine cracks filled } \\
\text { with coarse-grained calcite. Medium scale folds are clearly identifiable. }\end{array}$ \\
\hline $\begin{array}{l}\text { Unit I } \\
\text { Clay-carbonate cal- } \\
\text { crete }\end{array}$ & $\begin{array}{l}\text { This lowest unit of the exposed section is a mixture of carbonate and little dark } \\
\text { coloured clay. Calcite filled cracks of varying sizes are present. }\end{array}$ \\
\hline
\end{tabular}

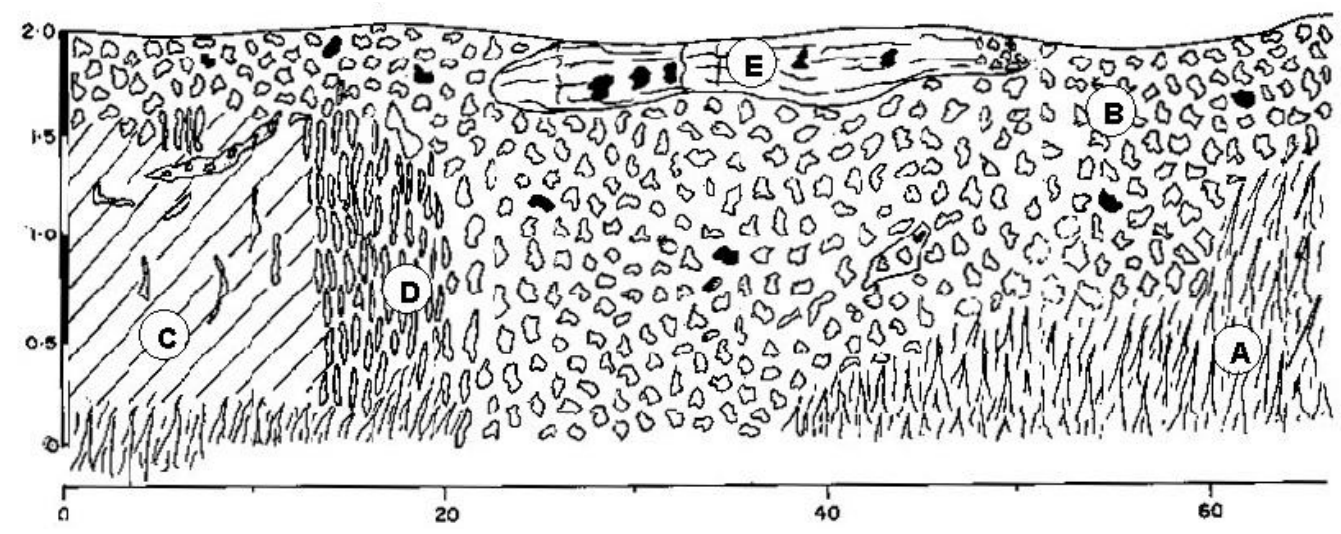

Figure 13. Lateral profile of the Ringan section. The calcrete is developed in regolith of mica-schist of Delhi Supergroup and a variety of facies are seen: (A)-regolith with patchy calcrete; (B)-nodular calcrete; (C)-massive (vertically oriented fabric) calcrete; (D)- degraded form of 'c', (E)-hardpan.

\subsection{Anwana section}

This section $\left(73^{\circ} 08^{\prime} 38^{\prime \prime} \mathrm{E} ; 26^{\circ} 39^{\prime} 48^{\prime \prime} N\right)$ is located $\sim 45 \mathrm{~km}$ NNE of Jodhpur town. It is developed in sandstone called the Sonia Formation (Jodh- pur Group) of Marwar Supergroup of Proterozoic age. The section comprises $15 \mathrm{~m}$ of exposed strata in an $18 \mathrm{~m}$ deep step-well. Based on physical and macromorphological considerations, the section can be divided into eight units (figure 14 and 
Table 8. Stable isotope composition of ancient calcretes (\%o PDB).

\begin{tabular}{|c|c|c|c|c|c|}
\hline Anwana & $\delta^{13} \mathrm{C} \%$ o & $\delta^{18} \mathrm{O} \%$ & Other calcretes & $\delta^{13} \mathrm{C} \%$ & $\delta^{18} \mathrm{O} \%$ \\
\hline Unit VIII Pisolitic calcrete & & & Katoti Hardpan & & \\
\hline Inner nucleus & 0.20 & -7.20 & Red groundmass & -0.2 & -7 \\
\hline Rusty micritic coating & 0.56 & -4.92 & Light red groundmass & 0.5 & -5.4 \\
\hline \multirow{2}{*}{$\begin{array}{l}\text { Unit VII Laminar calcrete } \\
\text { Laminae }\end{array}$} & \multirow[b]{2}{*}{1.08} & \multirow[b]{2}{*}{-2.30} & Dark red pisolite & 0.2 & -5 \\
\hline & & & White young infilling & 0.9 & -6.2 \\
\hline \multirow{2}{*}{\multicolumn{3}{|c|}{$\begin{array}{l}\text { Unit VIII Brecciated } \\
\text { hardpan calcrete }\end{array}$}} & Uppermost laminae & -1.2 & -5.7 \\
\hline & & & \multicolumn{3}{|l|}{ Nimbli Jodhan } \\
\hline Indurated pisolites & 0.38 & -6.83 & Nodule-light brown & 0.7 & -5.9 \\
\hline Micritic groundmass & -4.46 & -6.52 & groundmass & & \\
\hline Crystallaria & -3.43 & -5.75 & Nodule-dark brown & 0.1 & -5.5 \\
\hline Breccia fill cement & -0.82 & -6.58 & domain & & \\
\hline \multicolumn{3}{|l|}{ Unit VI Massive calcrete } & \multicolumn{3}{|l|}{ Lordian } \\
\hline \multirow{2}{*}{$\begin{array}{l}\text { Micrite } 1 \\
\text { Micrite } 2\end{array}$} & \multirow{2}{*}{$\begin{array}{l}-5.1 \\
-4.32\end{array}$} & \multirow{2}{*}{$\begin{array}{l}-5.45 \\
-6.3\end{array}$} & Hardpan-groundmass & 0.6 & -3.7 \\
\hline & & & \multirow{4}{*}{$\begin{array}{l}\text { Chandrok } \\
\text { Nodule-reddish } \\
\text { groundmass } \\
\text { Neoformed cement }\end{array}$} & & \\
\hline \multicolumn{3}{|l|}{ Unit IV Massive calcrete } & & 0.8 & -5.4 \\
\hline Micrite 1 & -3.45 & -5.58 & & & \\
\hline Micrite 2 & -5.61 & -6.25 & & 0.2 & -3.7 \\
\hline \multicolumn{2}{|l|}{ Unit III Calcrete } & & \multicolumn{3}{|l|}{ Ringan } \\
\hline Micrite 1 & -3.06 & -6.56 & Hardpan & 0.2 & -5.6 \\
\hline \multirow[t]{2}{*}{ Micrite 2} & -4.57 & -4.87 & Nodule & 0.4 & -5.5 \\
\hline & & & Vertical fabric & 0.2 & -5.6 \\
\hline
\end{tabular}

plate $7 \mathrm{~d}$ ). Crude stratification of the chert layers broadly parallels the stratification of the sandstone. Except for the upper most unit, the remaining seven units are affected by an asymmetric fold (non-tectonic). Description of individual units is given in table 7 .

Five major facies, each with its own distinctive fabric and organization, have been recognized (Sharma 1999). These are:

\subsubsection{Brecciated hardpan facies}

It comprises highly indurated nodules in a carbonate matrix. Nodules constitute up to 50 $60 \%$ of the calcrete. These are sub-spherical to highly irregular in shape and vary from sub-mm to $\mathrm{cm}$-sized features. Brecciation cracks are filled with carbonate-rich detritus. Other features are: dark brown clay-micrite glaebules, pendant structures, brecciated fabrics comprising circumgranular to curvilinear cracks filled by spar/microspar (plate 7e). Two types of nodules, detritus-poor and detritus-rich are recognized. Inter-nodular material consists of clay-micrite patches with uniform to irregular distribution. Clastic detritus (quartz, polycrystalline quartz, feldspar, and opaques) from $<100 \mu \mathrm{m}$ up to $4 \mathrm{~mm}$ is present. Brecciation accompanied by multiple fracturing of the older nodules and re-cementation is also observed. The cracks are filled up with elongated but generally equant, subhedral and large rhombic crystals of calcite that may be as large as $250 \mu \mathrm{m}$ and show crystic plasmic fabric.

\subsubsection{Other facies}

The pisolitic facies occurs as an associated feature in the brecciated hardpan calcrete. Pisolites are present in the indurated hardpan as well as in the breccia crack infillings. The concentric growth of the pisolites is made up of dense micrite (plate $7 \mathrm{f}$ ). The laminar calcrete facies is marked by subhorizontal to curvilinear laminae that are defined by colour variations from gray brown to light brown micrite. These have a thickness ranging from 2 $4 \mathrm{~mm}$. The laminar fabric also shows inter-layering of coarse, elongate to equant grains of spar with dark brown micrite. The chalky calcrete facies is marked by light gray to green colour and unconsolidated silt-sized calcite particles. Clay-micrite groundmass shows clotted texture with uniform to irregular distribution. Quartz detritus is floating in the groundmass. The massive calcrete facies has a micrite groundmass with pockets of light brown clay rich material and detrital quartz grains of variable size. Clay-micrite areas show clotted texture. Spar-filled vughs show an increase in crystal size 
Table 9. ESR dating results of ancient calcretes.

\begin{tabular}{lccr}
\hline Description of calcrete & $\begin{array}{c}\text { Equivalent } \\
\text { dose }(\mathrm{Gy})\end{array}$ & $\begin{array}{c}\text { Dose rate } \\
(\mathrm{Gy} / \mathrm{ka})\end{array}$ & $\begin{array}{r}\text { Age } \\
(\mathrm{ka})\end{array}$ \\
\hline Ringan & 815 & 0.99 & 809 \\
\hline Hardpan & 910 & 0.96 & 876 \\
\hline Nodule & 1050 & 0.88 & 1193 \\
\hline Massive-vertical fabric & & & \\
\hline Anwana & 2325 & 1.5 & 1550 \\
\hline Hardpan & 900 & 1.5 & 600 \\
\hline Breccia fill & 1200 & 1.5 & 900 \\
\hline Chalky & & & 850 \\
\hline Katoti hardpan & 1850 & 0.95 & 1542 \\
\hline Light red infilll & 896 & 0.91 & 985 \\
\hline Dark red groundmass & 760 & 0.8 & 950 \\
\hline Ratau lower nodule & 465 & 0.83 & 560 \\
\hline Nimbli Jodhan nodule lower & 1200 & 1.05 & 1143 \\
\hline Badela upper nodule & 1150 & 1.12 & 1027 \\
\hline Dhurila nodule & 855 & 0.84 & \\
\hline Lordian nodule & & & 1.18 \\
\hline Chandrok nodule & & & \\
\hline Badgaon upper nodule & & & \\
\hline
\end{tabular}

from wall to core and represent an open space growth.

\subsubsection{Cathodoluminescence}

The micrite groundmass of the brecciated hardpan calcrete and the nodules embedded in it reveal orange luminescence. The small clay-carbonate patches within the calcrete groundmass show dull orange luminescence. The spar associated with brecciated fabric, cavity and circumgranular crack fills, and that of dissolution-precipitation phases along inter-crystalline boundaries often shows a zoned luminescence. Plate 8(a) is of a spar filled crack. Under CL (plate 8b), the micritic groundmass is orange luminescent but the open space spar in the immediate vicinity is non-luminescent to dull orange luminescent. The rest of the spar shows a bright orange, zoned luminescence. From the petrographic and luminescence studies, the sequence of development is given in figure 15 . The micrite groundmass in chalky calcrete is dull orange luminescent but spar filling the crack is orange luminescent whereas the cavity fill is nonluminescent. The massive calcrete has orange luminescent groundmass with irregular patches that are non-luminescent.

\subsubsection{Stable isotopes}

Data on Anwana and other ancient calcretes is presented in table 8 . The pisolitic calcrete and the laminar calcrete in units VII and VIII of Anwana section have $\delta^{13} \mathrm{C}$ values between 0.2 and $1.1 \%$. The indurated pisolites and breccia-fill cement show similar values but the micritic groundmass and the crystallaria in it have distinctly more negative values at -4.4 and $-3.4 \%$. The massive calcrete of units VI, IV and II that underlie the brecciated hardpan calcrete also have similar isotopic signatures. Thus a clear difference is seen in the $\delta^{13} \mathrm{C}$ values of the neoformations in the upper part of the brecciated hardpan calcrete and in the original hardpan and the rest of the profile. The $\delta^{18} \mathrm{O}$ values, like those of sheetwash aggraded plain calcretes, indicate slightly to moderately evaporated meteoric waters.

\subsubsection{Synthesis}

The features of the individual facies in the profile can be combined to obtain a composite model for the development of the Anwana duricrust. The initial stage is the formation of regolith through brecciation and weathering of the host sandstone. 


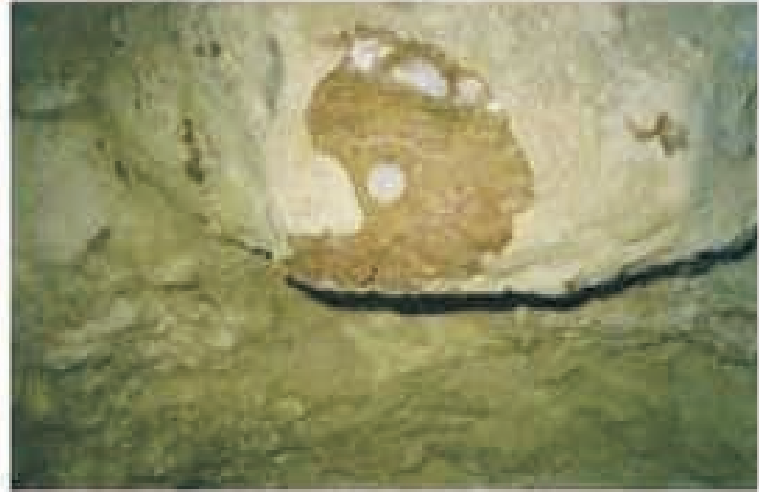

(a)

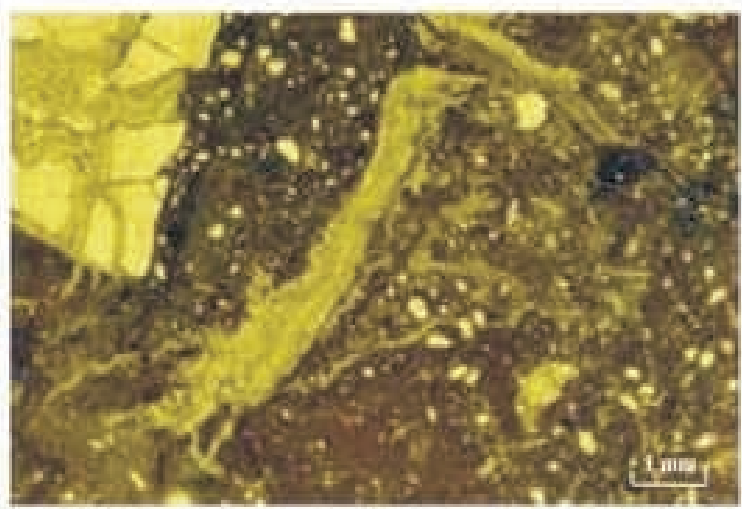

(c)

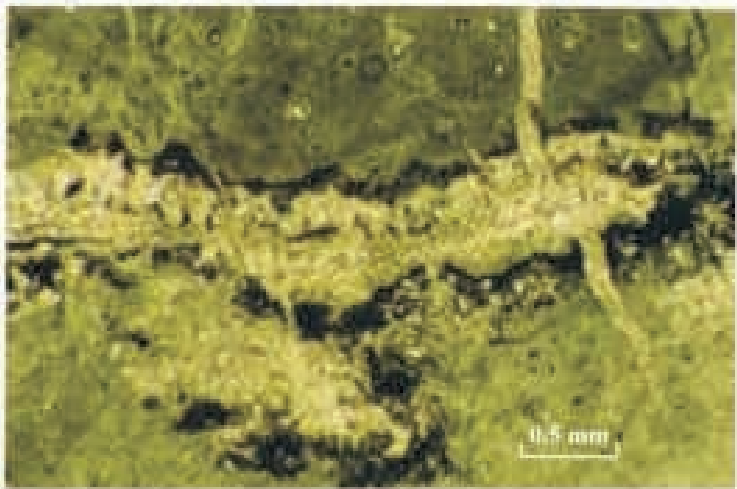

(e)

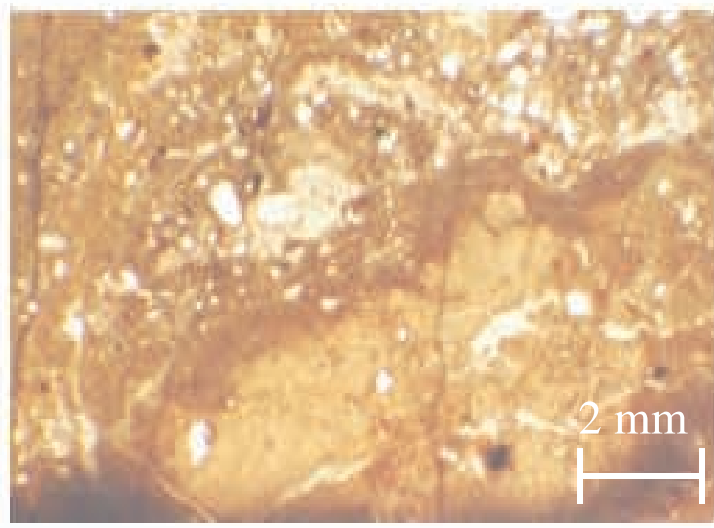

(b)

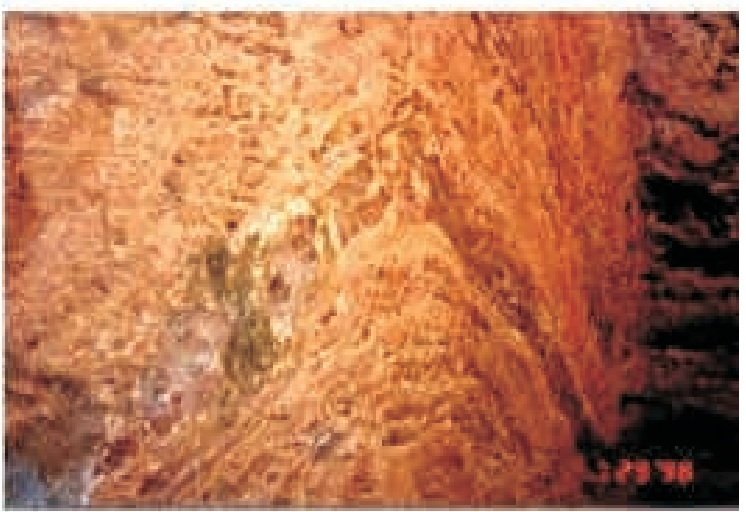

(d)

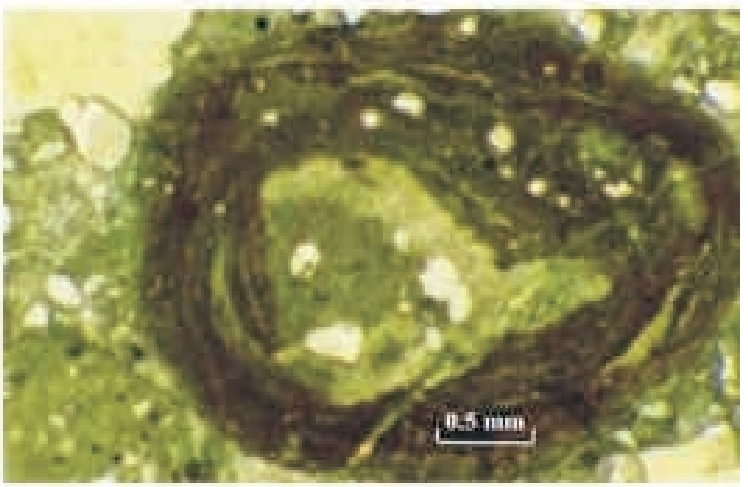

(f)

Plate 7. (a) View of the impersistent hardpan $(\sim 70-80 \mathrm{~cm}$ thick $)$ that caps the section. The light red hardpan mass is traversed by sheet cracks. Coin for scale is $2.5 \mathrm{~cm}$ across; (b) Photomicrograph of hardpan showing the micritic groundmass with common siliciclastic grains. At the right bottom is an occasionally present nodule; (c) Photomicrograph of hardpan showing a shrinkage crack filled with zoned calcite. Also seen is an exploded vein quartz fragment with calcite infillings; (d) Field view of basal 2.5 meters of Anwana section showing the lower part of Unit VIII and the underlying units. (e) Photomicrograph of brecciated hardpan calcrete showing discordantly related spar filled crack. Note the dark, dominantly clay-micrite, deposit at the boundary of the infilling; (f) Photomicrograph of a pisolite in the brecciated hardpan calcrete. The dark envelope is clay-micrite mixture. 


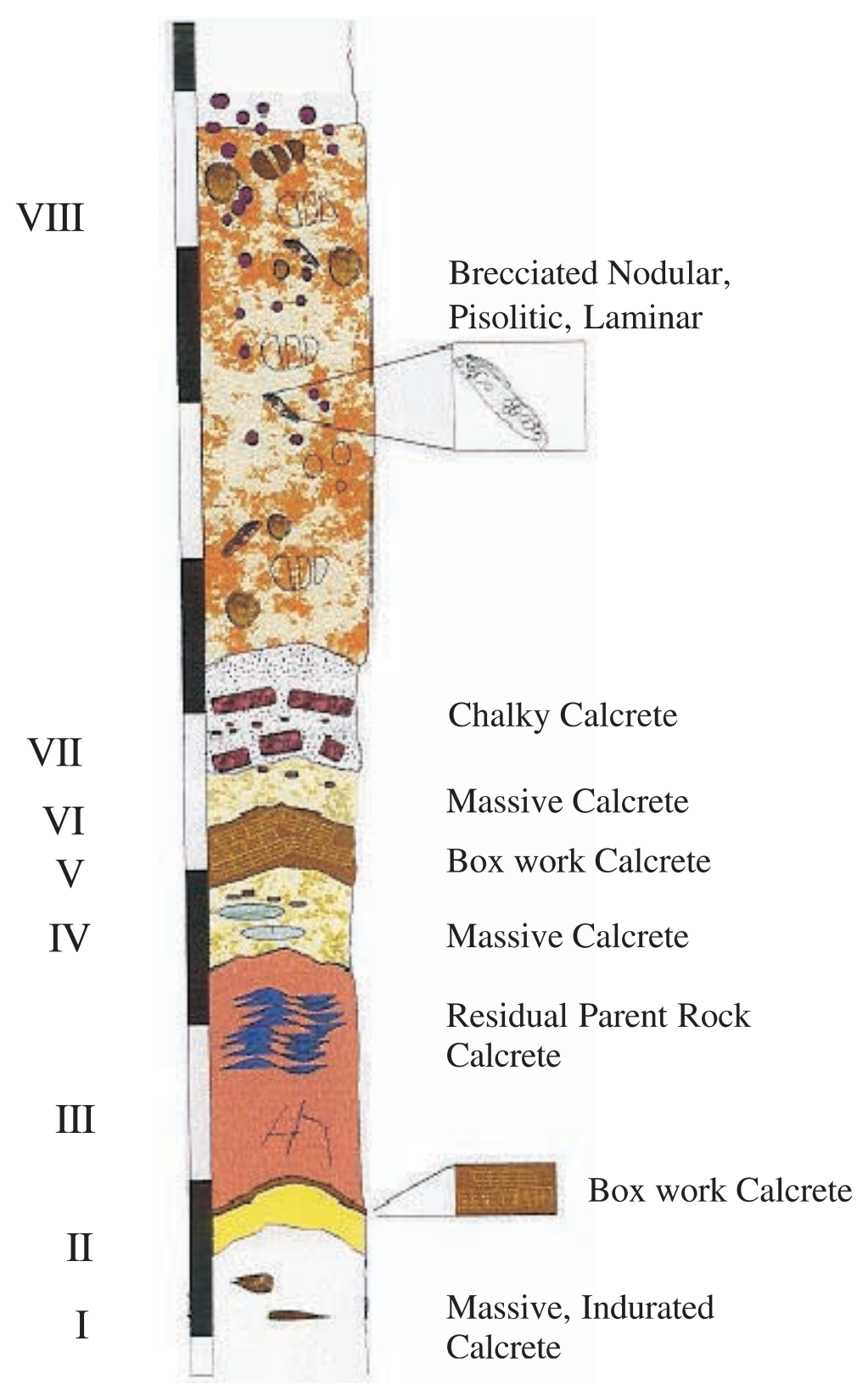

Figure 14. Field log of the calcrete at Anwana. It is an example of highly evolved calcrete morphology seen in the region.

Formation of regolith occurred under fluctuating groundwater table. Expansion of clays during wetting resulted in an upward pressure and development of deformation of the consolidated layers above. The Unit VIII being in an unconsolidated state remained undeformed. Simultaneously, the precipitation of calcite from groundwater continued. The formation of cracks in the clay rich part of the host rock marked a period of desiccation in a vadose setting. With increase in the magnitude of fluctuation in groundwater table, the carbonates reached the upper part of the loose host rock. ESR data suggest that such fluctuating regime occurred in the time frame of 1900 to $1550 \mathrm{ka}$ (table 9). The dry and wet seasonal setting caused differentiation

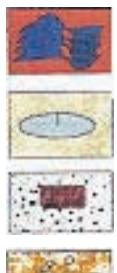

Deformation features

Parent rock grey chert

Parent rock maroon chert

Red carbonate nodule

Box work

Fault planes

Clay-rich pockets

Solution channel with nodular laminar calcrete

Pisolitic calcrete

Brecciated nodular calcrete of the cement into nodules. Cementation in lower horizons continued and culminated in deformation. Plugging of the horizon with carbonate, possibly supplied by run-off waters, followed this.

After this stage, the upper strata of the section (unit VIII) underwent brecciation and dissolution while cementation continued in the lower units. Due to decrease in porosity, precipitation of thin discontinuous laminar fabric enveloping the nodules or the calcrete fragments took place. The supermature calcrete of Unit VIII shows brecciation cracks, which are filled by the overlying sediments and replaced by younger cement. This event of carbonate enrichment occurred at around 800 to $600 \mathrm{ka}$. The movement of carbonate fluids 


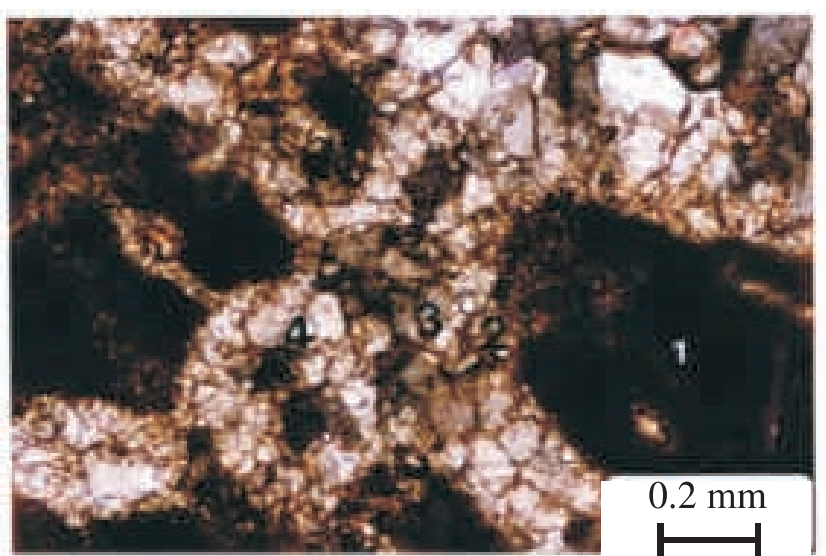

(a)

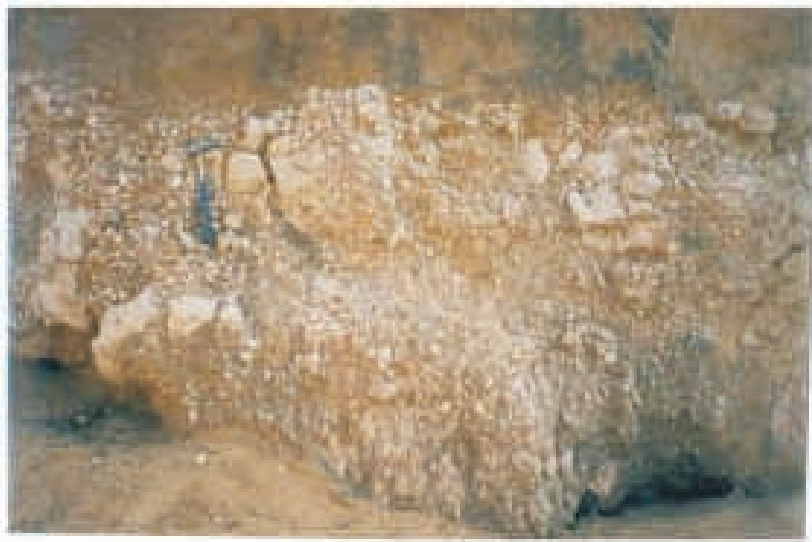

(c)

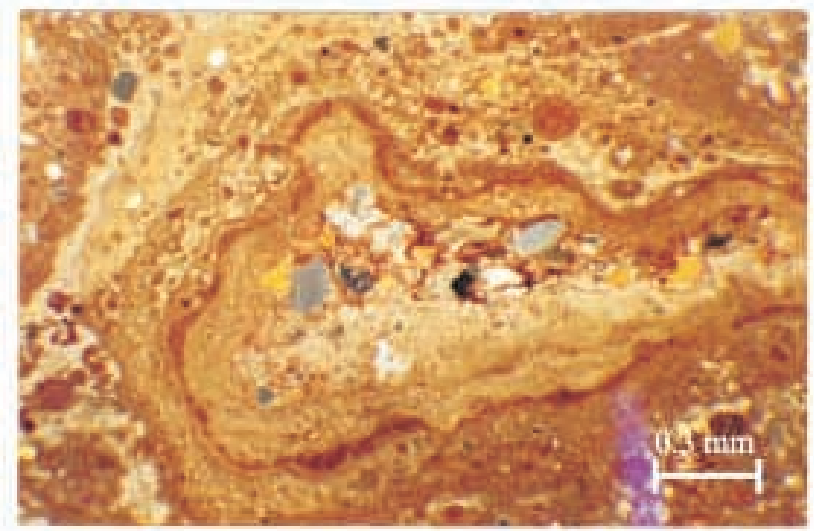

(e)

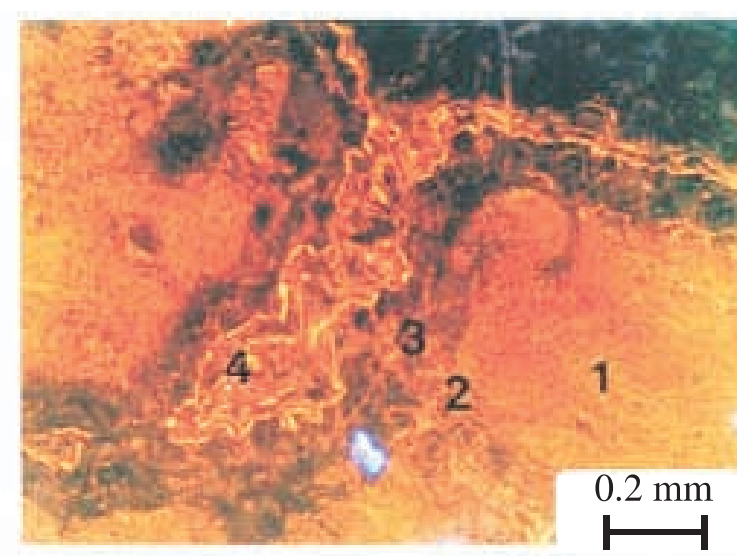

(b)

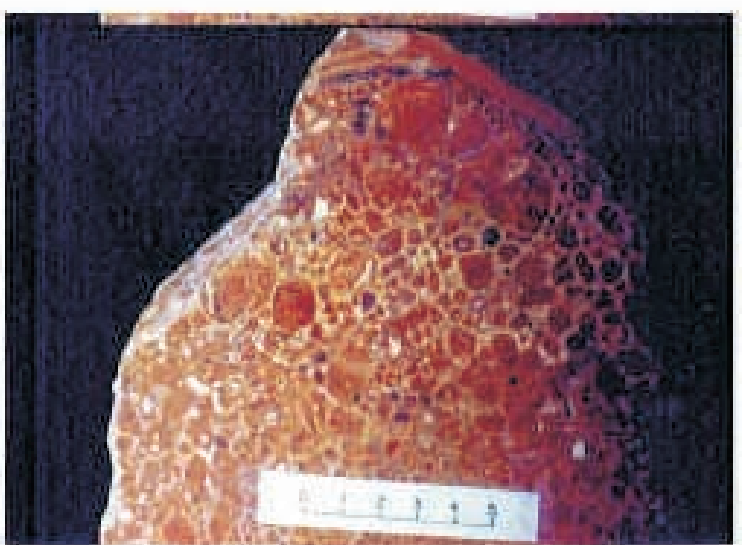

(d)

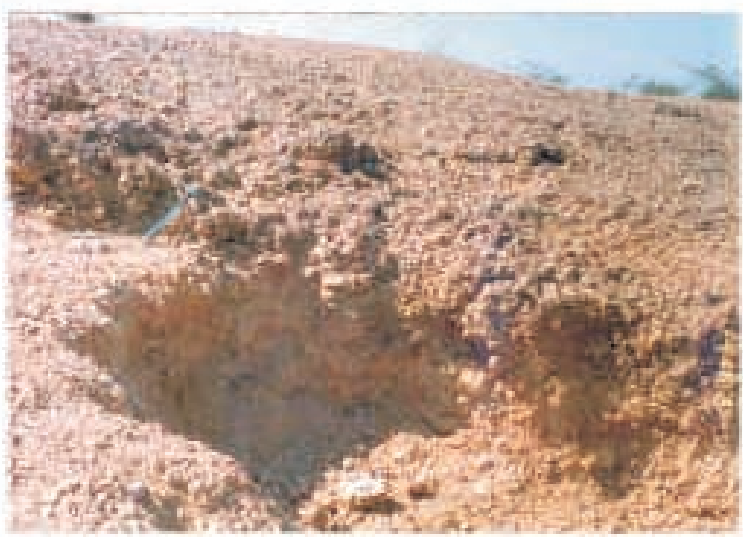

(f)

Plate 8. (a) Photomicrograph of brecciated hardpan calcrete showing a spar-filled crack in the densely micritic groundmass; (b) Same under CL. The densely micritic groundmass (1) is orange luminescent; the spar is luminescent (2) to non-luminescent (3). In its central part the spar is zoned luminescent (4); (c) Field view of the Katoti Section. Note the thick hardpan and its intense brecciation; (d) Polished slab section of the hardpan of Katoti showing rounded grains of the original hardpan and pisolites cemented by younger carbonate. At the top is a patchy laminar calcrete; (e) Close-up of a pisolite in the Katoti section; (f) Field view of the mound-like feature where Chandrok section is located. Such mounds are remnants of an older alluvial surface. The calcrete profile is truncated and dismantled. 


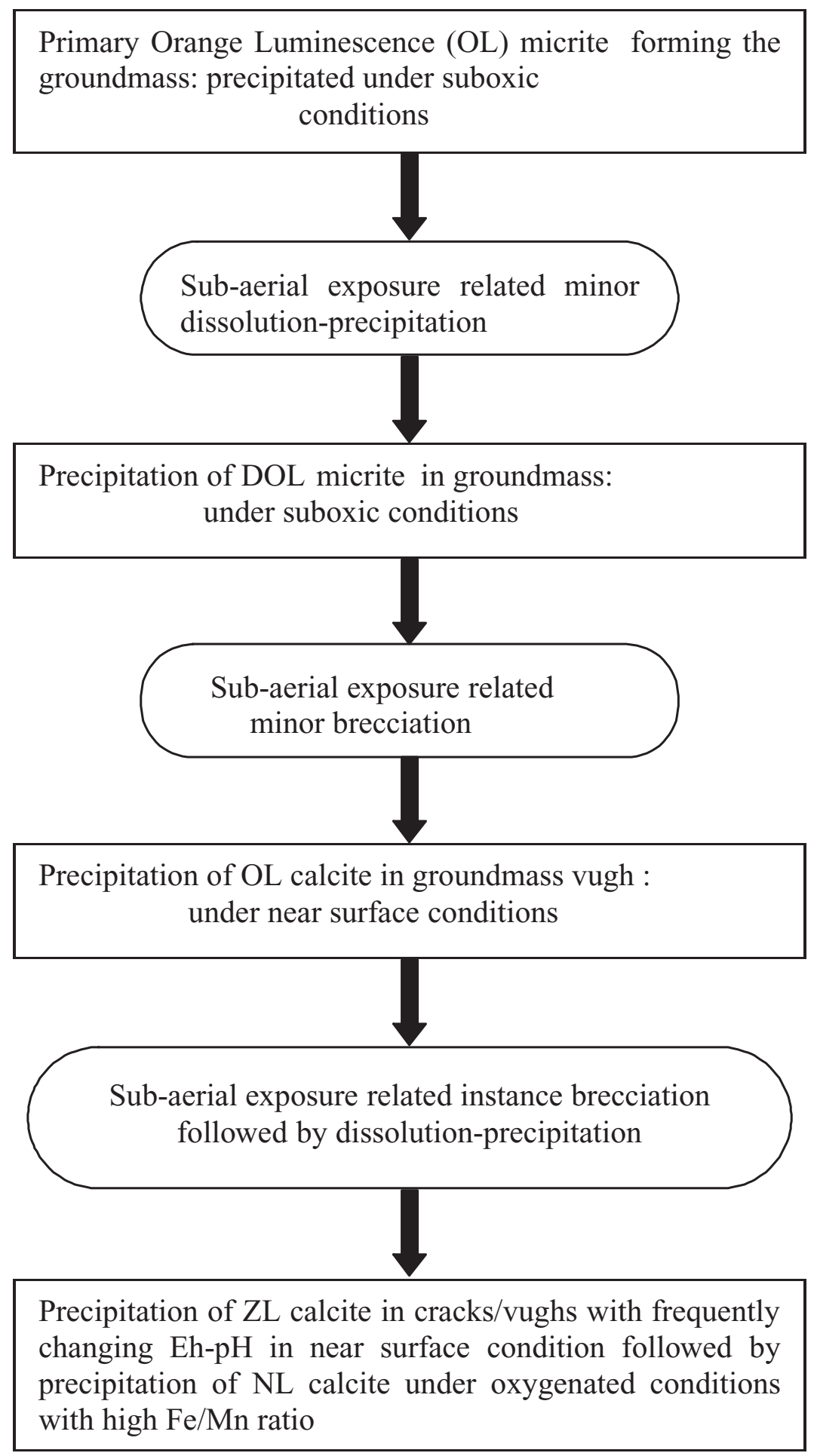

Figure 15. Cement stratigraphy, precipitation and dissolution sequence of brecciated hardpan calcrete in Anwana section.

in Unit VIII and Unit VII followed the brecciation, and Unit VII was affected by replacement during recementation.

\subsection{Other sections}

A brief description of the remaining sections is summarized in table 6. Some of these are devel- oped in regolith and others in alluvial deposits. The Katoti section lies in the colluvio-alluvial plain in a gently sloping area to the north of Jayal ridge. The section comprises a thick hardpan and a nodular calcrete underneath (plate 8c). The hardpan is highly fractured. Polished slabs (plate 8d) show complex features comprising peloids i.e. rounded fragments of the original hardpan and few pisolites, 
both cemented by younger cement. In fact two generations of this subsequent cement, one light red calcite and the other whitish calcite are discernible. The upper part has a thin patchy laminar calcrete. The pisolites show a core with several concentric laminae (plate 8e). EPMA results suggest that the core comprises calcite with traces of free $\mathrm{Fe}$ and clay. Locally, grains of siderite-clay mixture were also seen. Nearly opaque laminae contain iron. The original hardpan is dated $\sim 1500 \mathrm{ka}$ whereas the light brown calcite infill is much younger $(\sim 900 \mathrm{ka})$. The Chandrok section is representative of calcrete outcrops that occur as scattered remnants of an older surface amidst the sheetwash aggraded plains. These occur as mounds extending over a fraction of a square kilometer (plate 8f). The surface has a lag deposit consisting of chert, quartz, hardpan calcrete, quartzite etc. The surfaces of boulders show development of laminar calcrete. The preserved profile shows nodular and lumpy calcrete with a rather simple fabric and much of the original profile has been denuded away. The boulder calcrete gave a date of $\sim 1000 \mathrm{ka}$.

\subsection{Stable isotopes in ancient calcretes}

The stable isotope data on various calcretes is given in table 8. Of these, the data on Anwana have been described earlier. The $\delta^{13} \mathrm{C}$ values in Ringan vary in a narrow range of 0.2 to $0.4 \%$. Values from other calcretes are in the same range with some features in Katoti hardpan showing a value of -0.2 and $-1.2 \%$. The difference is small and is suggestive of vegetation of an overall dry climate. The $\delta^{18} \mathrm{O}$ values are in the range of -5 to $-6 \%$.

\section{Inferences on ancient calcretes}

- Calcrete occurrences: Some of the calcretes have developed in regolith whereas others are in alluvial aggradations. Often, the latter have considerable concentrations of cobbles and pebbles. Such aggradations with colluvial elements are observed across the region, including the most arid part of Jaisalmer and Barmer. The presence of coarse clasts is rare in sheetwash alluvial aggradation of middle Pleistocene age. Though the Didwana section shows some persistence of coarse clasts, elsewhere in the region, these occur as isolated mounds or positive relief features amidst younger sheetwash aggraded plains or aeolian plains. The profiles are often truncated or dismantled, with lags covering the surface.

- Evolved morphologies: Though nodular forms are common here also, the ancient calcretes possess evolved morphologies. The hardpan of Ringan section shows brecciation, dissolution and recementation events subsequent to the initial formation. Upper part of hardpan at Katoti has peloids that are cemented by two generations of cements. The thick, brecciated hardpan calcrete at Anwana with dissolutional degradation and pisolitic and laminar calcrete shows a very high order of evolution. The calcrete growth models of Machette (1985) and Goudie (1983) suggest that after the formation of a plugged horizon, further evolution is in the form of laminar calcretes over the hardpan. But such laminar calcretes do not occur extensively in the region. These occur as localized features as in Anwana or as patchy, thin capping as at Katoti. The reason for this incomplete evolutionary development possibly lies in the manner of carbonate enrichment, which is local redistribution and not progressive accumulation from a regional source like the dust.

- Antiquity of calcretes: Chronometric data on the calcretes is presented in table 9 . The age range of 600 ka to 2000 ka clearly suggests that these calcretes belong to early Pleistocene. The episodes of calcrete development appear quite spread out chronologically even within a given area as exemplified by the Ringan, Katoti, Badela and Dhurila sections in Didwana area. For the region as a whole, episodes of calcrete development appear to be concentrated at $\sim 600,900$ 1100 and 1500-2000 ka. Further, chronological data indicates that the calcrete sections have been evolving over time. The Anwana calcrete shows features ranging from $600 \mathrm{ka}$ to $1900 \mathrm{ka}$. The Katoti hardpan has a groundmass dated to $1542 \mathrm{ka}$ and the younger calcite fill is only $850 \mathrm{ka}$ old. The individual facies in Ringan date from 1200 to $800 \mathrm{ka}$.

- Host material replacement in calcrete genesis: Calcretes have formed in regolith and in transported sediments. The massive calcrete with well-preserved fabric of original mica schist host at Ringan is a clear case of calcrete development without a regolith stage. The Sardi and Lalasari sections in amphibolite/chlorite schist show similar mechanism also. Thus it seems that mica, chlorite and amphibole are quite vulnerable to replacement in process of calcrete development. The extreme case is of Anwana, where even quartz sandstone experienced a large-scale replacement.

\section{Discussion}

The calcretes in the Thar desert have an extensive geographical spread and the amount of carbonate stored in them is of the order of 0.8 to 2.4 tons $\mathrm{m}^{2-}$. The host material for the calcretes ranges from 
bedrock regolith, to alluvial/sheetwash deposits and aeolian sands. The calcrete occurrences in the Thar region show a wide spread of ages spanning the entire Quaternary. Nodular form is a pronounced feature in the calcrete deposits; however, the older calcretes additionally show several complex and evolved morphologies. Some of these aspects are discussed below.

\subsection{Calcrete host materials}

Aeolian sand plains and dunes constitute the dominant cover in the region. Their thickness shows a large spatial variability (Dhir et al 1994). The oldest aeolian member in the Chamu section dates to $\sim 150 \mathrm{ka}$. The bottom member of the 18-meter deep section at Didwana with Paleolithic tools (Misra et al 1982) has been TL dated to $160 \mathrm{ka}$ by Raghavan and Courty (1987). Kar et al (2001) reported a similar age for aeolian deposits from the basal part of the Khudala section on the Luni River. The absence of aeolian deposits in association with the older calcretes across the Thar region indicates that the aeolian sands became a prominent landscape element only from later midPleistocene. Jain et al (1999) also allude to this late origin for aeolian dynamism. The aeolian activity was episodic and the chronological data from the Chamu and Trijunction sections suggests that the periods of aeolian accretion occurred at $\sim 150$, $\sim 100,40-60$ and at 27 to $14 \mathrm{ka}$. These episodes were followed by periods of climate amelioration that resulted in surface stability and calcrete formation. The locally present stronger calcretes formed by perched or groundwater (lensoid, rhizocretions and bands at depths of 7-8 meters at Chamu and patchy calcretes in sandy plains elsewhere) possibly owe their origin to such periods of increased precipitation.

A sheetwash aggradational phase is characteristic of the mid-Pleistocene. These sequences, exposed at the surface or occurring under a thin mantle of aeolian sands are widespread in the present day 300-400 $\mathrm{mm}$ rainfall zone of disorganized drainage as also in the more arid parts in Jaisalmer and Barmer. This aggradation with calcrete development was episodic, and, as shown later, also associated with pronounced raised groundwater regimes. Such an aggradation is very localized in the modern landscapes, and is confined to favourable situations in the vicinity of rocky/hilly catchments. Therefore, it seems that the sediments and carbonate accumulation in these occurred under climate conditions wetter than those that prevailed during the late Pleistocene.

The early Pleistocene calcretes are hosted in alluvial deposits, and several of these occur in colluvio-alluvial plains that have been interpreted by Achyuthan and Rajaguru (1997) as deposits of braided high-energy bedload streams. Besides, most of these occur as isolated elements within the younger sheetwash deposits. Some lie at the floor of valleys, the flanks of which have since been eroded, and thus represent a case of relief inversion (Dhir 1995). Probably, a gentle, regional upliftment and a change in the baselevel of erosion also occurred. Denudation may have also been facilitated by episodic desiccation accompanied by a reduction of the vegetation cover.

Summing up, a shift from a semi-arid climate took place from the late mid-Pleistocene towards an arid climate during which aeolian dynamism became significant. The aeolian dynamism was episodic with intervening periods of stability and calcrete formation. The calcretes at Chamu and Trijunction show such a prominent period at 40 $60 \mathrm{ka}$; and this shows general correspondence to the red horizon described by Tandon et al (1997) in the Sabarmati Basin in Gujarat and with a period of intensified monsoon recorded in Tibetan ice core (Thompson et al 1997). The mid-Pleistocene sheetwash aggradation and the calcretes developed therein are broadly coeval with Paleosols $\mathrm{S}_{2}$ to $\mathrm{S}_{5}$ in the loess deposits of China. In the absence of a rigorous chronological framework, these correlations within the Asian monsoon region are tentative.

\subsection{Source of carbonate and mode of enrichment}

Dust, rainwater, surface runoff, groundwater, sea sprays, bioclasts, vegetation litter and calcareous host sediments have been recognized as the possible sources of calcium carbonate (Wright and Tucker 1991). The profiles in dunes and sandy plains show a non-calcareous or weakly calcareous, depleted upper solum which grade into a zone of maximum carbonate accumulation at a depth corresponding to the wetting front i.e., a typical redistribution pattern resulting from pedogenesis. The individual calcretes in Chamu have developed similarly, and where the depleted zone is not observed presently, evidence does exist of its having been stripped away. Evidence suggesting a major role of dust as a source for calcretes in the aeolian sediments is limited despite the fact that:

- the dust is fairly calcareous (Sidhu 1977) and

- the presence of thick calcretes in piedmonts off the hills and outcrops of sandstone and rhyolite show a contribution from the dust.

Firstly, the amount of carbonate in these modestly developed calcretes is not such as can not be explained by a vertical redistribution of the 
detritally held carbonate. The aeolian sands on an average have $2-4 \%$ carbonate and a meter or so of thickness is enough to account for the observed enrichment. Secondly, had the dust been a major source, the older calcretes should have a capping of younger calcretes, which is not the case. It seems as if the Thar desert acted more as a source rather than as a sink for the calcareous dust.

In the nearly level sheetwash aggraded plains, the deep sections show a sequence of calcretes. Individual calcretes often have clasts of transported nodules and sand-sized carbonate grains at their base. Thus, it seems that the host sediments were initially rich in calcium carbonate, the source being the proximal, pre-existing calcretes. The upper boundary of the individual calcretes is abrupt and planar (plate $5 \mathrm{f}$ ). The examination of several quarries across a given site, as for example at Banar, suggests that a near horizontal level is maintained across on a $\mathrm{km}$ scale. The presence of massively cemented cross-stratified alluvial sands/ gravels and sheet sediments, noted in several of the deep sections is caused by groundwater cementation. Thus, it seems that further enrichment of the host sediments occurred from carbonate-rich groundwaters. Since these calcretes are quite widespread, the setting requires a regional regime of raised groundwater, at least periodically. Such a situation is facilitated by the limited thickness of sediments (5-10 meters) that overlie the consolidated bedrock, given a wetter climate interlude. Khadkikar et al $(1998 ; 2000)$ have also recorded extensive occurrence of groundwater calcretes in Quaternary sequences in northern Gujarat.

The early Pleistocene calcretes occur in hosts that are not particularly calcareous and there are no rocks in the immediate vicinity that could have acted as a source. The thick Anawana calcrete crust owes the enrichment of the host material to ground water in its early period and later to sheet flow. The Ringan section, because of its non-uniform enrichment seems to have sheetflow as source. But what was the original source remains, as yet, enigmatic. The Bilara Formation (limestone and dolomite) and carbonate members in the Delhi and Aravalli Supergroups to the east could have acted as sources in the past aggradation history. Carbonate dust from the Mesozoic and younger rocks to the west of the study area or the earlier mentioned Proterozoic source is an issue that needs a rigorous study with strontium isotopic fingerprinting.

\subsection{Calcrete morphologies and their genesis}

A variety of morphologies are observed in the studied calcretes; these are discussed below.

\subsubsection{Stack formation}

Deep sections (3-5 meters) in sheetwash sequences of the aggraded plains show a stack of calcretes. The individual calcretes are approximately a meter thick. At Banar and Osian, where it has been possible to make detailed observations, over laterally extensive areas, the individual calcretes are laterally persistent over a distance of up to a $\mathrm{km}$. The calcretes underlying the uppermost member show evidence of local erosion before being overlain by younger sheetwash deposits. Transported nodules usually mark the beginning of successive aggradational events in the stacks of calcretes. The available data on chronology suggest progressively younger age of individual calcretes, and also that the individual episodes of calcrete formation are separated by tens of thousands of years. Thus, it seems that the stack developed in separate episodes of sheet aggradation, each followed by calcrete development before the succeeding phase of aggradation and a calcrete development therein (cf. Tandon et al 1998).

\subsubsection{Nodule forms}

Nodules are a dominant feature of almost all the calcretes. The nodules occur as discrete bodies having sharp boundary with the surrounding matrix. The hard nodules in thin section show highly dispersed siliciclastic grains in a tightly packed calcite mosaic. The nodules are bodies, highly enriched in carbonates with respect to the medium in which they formed. Sehgal and Stoops (1972) have shown that the nodules develop from progressive growth of interflorescences, impregnative infillings and coating via spongy or chalky nodules. Wieder and Yaalon (1974), Courty and Fedoroff (1985) and Achyuthan and Rajaguru (1998) support the origin of nodules through similar processes. The mechanism pre-supposes a progressive enrichment of the medium with calcium carbonate, and hence is not applicable in the present case where a calcareous enriched medium, detrital and groundwater-sourced, already existed and no further contribution is envisaged during the period of nodule formation. The nodules here have evolved from a redistribution of the already existing carbonate. Chadwick and Nettleton (1990) have suggested that in a medium with heterogenous material, calcite preferentially grows on the carbonates than on the siliciclastic grains and organic materials because of the chemical affinity of the ionic bonding. It is this affinity, which makes the calcite mosaic grow, and in the process displace the host siliciclastic grains. However, the calcite mosaic comprising micrite-spar groundmass with sparry growth around host grains and shrinkage 
cavities, and in circumgranular and shrinkage cracks suggests several episodes of precipitation and dissolution in a subaerial environment. Several of the calcretes in the sheetwash sequences show hard nodules in the upper part, which grade downward into chalky/soft nodules. This implies that the hard nodules evolve via a soft, chalky stage. Thus, the inferences on mechanism of enrichment and nodule development under subaerial conditions seem to suggest that the calcretes are of a mixed origin. Therefore, it is not surprising that several of the differentiating criteria for discrimination between pedogenic calcretes and groundwater calcretes of Arakel and McConchie (1982), Wright and Tucker (1991), Pimentel et al (1996) and Nash and Smith (1998) in terms of thickness and their boundary distinctness, gross morphology and carbonate petrography cannot be applied unambiguously to the Thar calcretes. Khadkikar et al (2000) inferred a similar pedogenic nodule formation in originally groundwater calcretes in Mahi and Sabarmati basins of Gujarat.

\subsubsection{Hardpan formation}

The Sunari section shows distinct hardpan features, the upper one being laterally persistent over few tens of meters. This is a massive sheet calcrete. The hardpan at Ringan, though of variable thickness, is also a massive calcrete. The brecciated hardpan calcrete at the top in Anwana section is $\sim 3$ meter thick. It evolved by carbonate impregnation from fluctuating groundwaters and sheet flow, and simultaneous replacement of the host material. It is a case of a hardpan development by extensive carbonate impregnation mainly in a vadose environment. Because of continuous K-fabric, the hardpan is analogous to stage III-IV morphology of Machette (1985). However, an important difference is that the hardpans do not form a persistent element on landscape-scale. Further, though the Katoti section shows thin, patchy laminar calcrete over the hardpan, other sections are largely devoid of this. All that is seen here is a few micron to $\mathrm{mm}$ thick laminar coatings around brecciated surfaces and in solution cavities. Thus, laminar calcretes overlying the hardpan as a progressive growth stage in the classical sequence of calcrete profile development of Gile et al (1966) and Machette (1985) are poorly represented.

\subsubsection{Other features}

The early Pleistocene calcretes show more evolved morphologies in the form of intense brecciation of the upper, more competent hardpan and presence of peloids and pisolites. At Anwana, the upper member is a thick brecciated hardpan and is characterized by mechanical and chemical infilling of brecciated features, circumgranular crack fills, pisolites, pendant cements, collapsed structures and laminar features along solution cavities. Cathodoluminescence studies show zoned calcitic growths. Thus, repeated solution/precipitation events are indicated. The light grey calcite occurring as brecciated fills is dated to 600 ka whereas the original hardpan calcrete has been dated to 2550 ka. The features in Katoti calcrete show a time frame of about the same magnitude also. Thus, the morphologies are complex and involve time separated multiple episodes.

\subsection{Mineral transformations and neosynthesis}

The aeolian sands as also the sand fraction of alluvial plains, unaffected by calcrete formation, are dominated by quartz with subordinate amount of feldspars and $2-3 \%$ of heavy minerals. Thin sections of nodules in late Quaternary calcretes show almost entire margins of quartz grains and some corrosion of plagioclase. In the nodules developed in sheetwash aggraded plains, the quartz grains show the development of extensive corrosive margins; plagioclase grains occur rarely or are severely corroded. It, therefore, appears that during the formation of calcretes, sufficiently aggressive conditions do develop so as to cause decomposition and disintegration of the host siliciclastic grains, particularly of plagioclase. The Ringan section developed in mica schist and it has a prominent facies of massive calcrete with a vertically oriented relict schistose fabric, which is made up of tightly packed calcite with occasional residual grains of host rock (plate 6e). The preservation of relict schistosity in the calcrete suggests that the calcrete formed by replacement of the host rock without a regolith stage. Chlorite, amphibolite schists and gneisses also show such a replacement. The Anwana section shows extensive replacement even of the quartzose sandstone. Wang et al (1994) proposed a reaction model for the replacement of quartz in the process of calcrete development. A critical requirement is the presence of some amount of magnesium in the medium for the formation of transitory fibrous clay minerals and thus creation of unsaturated conditions with respect to $\mathrm{SiO}_{2}$. The model predicts a time span of couple of hundred thousand years for the quartzites and the mechanism is quicker in the case of alumino silicates. Such conditions are quite plausible in the Anwana section.

It has been shown (Krishna Murthi and Narayana 1968; Choudhari and Dhir, 1981, 1982) that the clay fraction in soils developed on sheetwash aggraded plains, and in the aeolian sands are dominated by illite, kaolinite, smectite and mixed layer minerals. Palygorskite is found as a minor 
constituent only. The present study on the calcretes developed in these sediments shows palygorskite as the dominant mineral. This and the supporting progressive increase with depth in Banar section clearly suggests its formation as a product of authigenic processes associated with calcrete formation itself. The presence of palygorskite in the calcretes of this region has been documented for the first time; but elsewhere this mineral has been widely reported in the calcretes (Bachman and Machette 1977; Watts 1980; McGrath and Hawley 1987; Monger and Daugherty 1991; and Eitel 1995).

Palygorskite can form from the transformation of existing minerals or from fluids in the calcrete milieu. Data on clay mineral composition of calcretes, for example of Banar (table 3), show decrease or even disappearance of originally occurring minerals. The diffractogram (figure 12) shows that the smectite peak is poorly defined. Watts (1980), Yaalon and Wieder (1976) and more recently Eitel (1995) also proposed such a transformation. Weaver and Beck (1977) suggested a mechanism of smectite tetrahedron inversion for the formation of palygorskite. Local presence of free aluminum oxide as shown by the electron microprobe analysis of calcrete groundmass suggests degradation of detritally present clay minerals. Thus, evidence does exist for degradation of smectite and other minerals. Besides the above pathway, the mode of occurrence of some of the palygorskite as crystals growing out in pore spaces or as bridges between grains strongly suggests its origin as a neosynthesis from solutions permeating the calcretes.

Several authors (Watts 1980; Singer et al 1995 and Eitel 1995) have indicated that for palygorskite to form, the solution has to be rich in magnesium and silica. The silica can be sourced to degradation of clays and other siliciclastic grains, given sufficient alkalinity; the source of magnesium is not quite obvious. The calcite groundmass is poor in magnesium. For the calcrete formed in sheetwash plains, the groundwater itself could be a source since appreciable amount of magnesium is present in the groundwaters of the region.

\subsection{Stable isotope data}

Stable isotope analysis of carbonates has emerged as a powerful tool in paleoenvironment interpretations. Data on different calcretes of the Thar region is summarized in figure 16 . The $\delta^{13} \mathrm{C}$ values for most of the calcretes from early to late Pleistocene on varied hosts lie in a narrow range of +1 to $-1 \%$, that are typical of $\mathrm{C} 4$ vegetation. Only in the Anwana section some of the facies have $\delta^{13} \mathrm{C}$ values of $-3 \%$ o to $-5 \%$. Though the values are consistent with the data on random calcrete samples from the Thar reported by Solomons et al (1978) or of Pendall and Amundson (1994) in an alluvial soil in neighbouring Pakistan, the results are inconsistent with our earlier inference of progressive deterioration of climate during the Quaternary, particularly during the late Pleistocene. One way to explain this pattern is that the high temperature regime and high seasonality of rainfall did not permit a significant change in vegetation type, irrespective of whether the rainfall in the past was $300 \mathrm{~mm}$ (arid) or $600 \mathrm{~mm}$ (semiarid). Presently, the area has abundant sunshine, a mean annual temperature of $\sim 28^{\circ} \mathrm{C}$, a rainy period of $\sim 3$ months and a dryness for the rest of the year; and there is no reason to believe that some of these parameters were different in the past period of ameliorated rainfall conditions. This argument finds support in the data of Cerling and Quade (1993), who showed that pronounced seasonality of rainfall and abundance of light in the prairies of mid-western USA with a rainfall of $600-700 \mathrm{~mm}$ permitted only a $\mathrm{C} 4$ dominated vegetation and the resultant soil carbonates carried signatures typical of this vegetation. Further, Ehleringer (1988) has shown that in arid environments, even C3 plants tend to have more positive values compared to the same type of plants growing in less water stressed environments.

Another explanation could be that the parental carbonate, detrital and groundwater sourced, did not acquire equilibrium with the soil $\mathrm{CO}_{2}$. Slate et al (1996) have cautioned against the use of stable isotope data from carbonates from hydromorphic paleosols. However, this situation does not seem applicable in our case as it has been shown that the nodular calcrete has formed by redistribution of parental carbonate and that their internal fabric shows multiple carbonate precipitation events under subaerial environment. Any dissolution should involve infusion of $\mathrm{CO}_{2}$ from soil and a new signature for the reprecipitated carbonate. A repetition of the process would result in a carbonate with $\delta^{13} \mathrm{C}$ close to that derived from soil $\mathrm{CO}_{2}$. Presence of rhizocretions in calcretes shows that vegetation was in existence. Further, sampling was done not only on a whole nodule but from several, optically-constrained locations within a nodule using a micro-drill so as not to miss subtle variations. But the results were no different. A third possibility is that there was a large contribution of atmospheric $\mathrm{CO}_{2}$ to soil $\mathrm{CO}_{2}$ in the medium of calcrete formation. A calcrete developed in soil $\mathrm{CO}_{2}$ derived from a mixture of biological-sourced $\mathrm{CO}_{2}$ of $\mathrm{C} 3$ vegetation and atmospheric $\mathrm{CO}_{2}$ could result in $\delta^{13} \mathrm{C}$ values of the calcrete similar to those observed in Thar calcretes. Quade et al (1989) and several others have shown that in soils with low respiration rate, as in the deserts, the carbonates in 


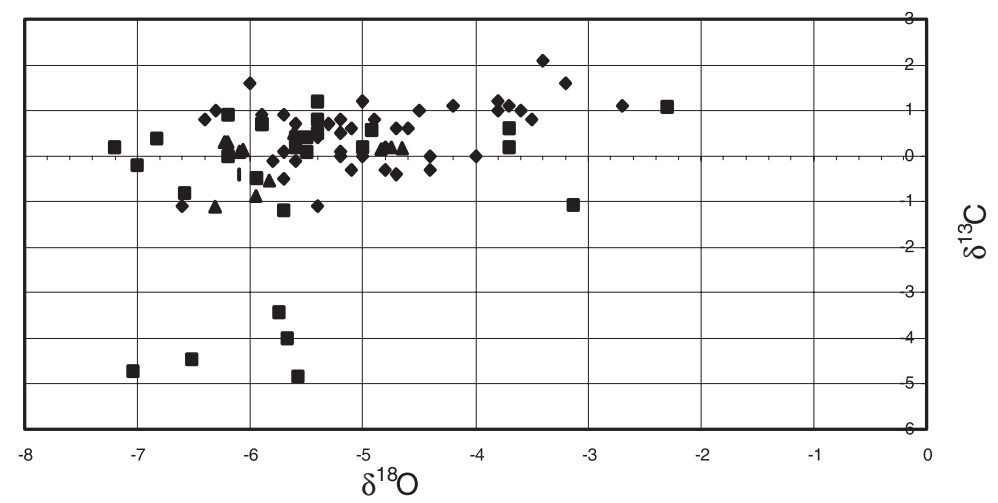

Figure 16. Stable isotope data of calcretes: $\boldsymbol{\Delta}$ - aeolian (late Pleistocene), $\bullet-$ sheetwash aggraded plains (mid Pleistocene) and $\mathbf{\square}$ - ancient (early Pleistocene).

the upper $60 \mathrm{~cm}$ soil depth carry significant contribution of atmospheric $\mathrm{CO}_{2}$. Low vegetation density in semi arid and arid regions results in low rates of soil respiration and therefore a significant spatial variation in the proportion of the atmospheric $\mathrm{CO}_{2}$ contribution, even though it may be small at greater depths, might exist (Deutz et al 2001). Such a spatial variability could explain at least some part of the observed variance.

\section{Conclusions}

Though field studies and morphologies were suggestive of varied antiquities of Thar calcretes, luminescence and electron spin resonance dating methods have for the first time provided a chronometric framework which shows that episodes of calcrete formation have occurred throughout the Quaternary. Much of the Quaternary is characterized by alluvial aggradations and aeolian sand host became prominent from late Pleistocene only. mid-Pleistocene sheetwash aggraded plains show an aggradation-dependent stack of calcretes, where carbonate enrichment of the initially calcareous host from raised groundwater has been suggested. However, nodular calcrete development occurred under sub-aerial conditions and thus these are a hybrid formation. Groundwater appears to have played a significant role also in older calcretes and to a limited extent in the late Pleistocene. The early Pleistocene calcretes, though often with truncated profiles, possess highly evolved morphologies with younger breccia-fill events half to a million years apart from the originally developed calcrete. A degradation of these calcretes appears to be a source of carbonates for the younger ones.

Nodule form is a dominant feature of the morphology of the calcretes of the region, and their origin from local redistribution of carbonate in the host medium has been argued. Evidence shows that sufficiently aggressive conditions do get created during calcrete development to cause degradation of clays and coarser siliciclastic minerals. In late Pleistocene calcretes this is manifest in the degradation of plagioclase but in early and mid-Pleistocene calcretes even quartz undergoes some degree of degradation. The early Quaternary Anwana calcrete in quartzose sandstone shows a major replacement of the host. Bedrocks of mica and chlorite schists are replaced even without their weathering into a regolith stage. Fibrous clay mineral, palygorskite, is mainly authigenic in calcretes, and its formation from the solutions permeating the calcretes and from degradation of detrital clay minerals is indicated. However, the source of magnesium needed for its formation remains enigmatic.

The late Pleistocene aeolian dynamism was episodic, with periods of surface stability and calcrete development. Stripping of upper solum and exposure of calcretes are indicated. The source of carbonate is possibly mainly detrital, and not the aeolian dust. But further analysis on the ultimate source of carbonate for these widespread calcretes, distantly located from the known exposures of calcareous bedrocks is warranted. Despite an exhaustive exercise, very narrow range of $\delta^{13} \mathrm{C}$ values for calcretes from inferred varied environments is striking. Probably pronounced seasonality of rainfall and abundance of sunshine did not permit a vegetation cover other than that of a $\mathrm{C} 4$ type. The present study has furthered the knowledge of the Thar calcretes by highlighting the enormous scope of detailed event stratigraphy of calcretes and for reconstructing the landscape evolution and paleoenvironments of this region.

\section{Acknowledgements}

The authors thank the Department of Science and Technology, Government of India for financial support for a coordinated project on the Thar desert 
(ESS/CA/A3-08/928). Particular indebtedness is due to Prof. A K Singhvi, Physical Research Laboratory, Ahmedabad for his coordination of the above project and for the stimulus and facilitation of the current manuscript in numerous ways. The authors thank the heads of their respective institutions for facilities provided. Clay mineralogical work and interpretations were kindly facilitated by Dr. D K Pal of NBSSLUP, Nagpur. Dr. S M Ahmed (NGRI, Hyderabad) kindly helped with some of the isotopic measurements. The valuable help in field discussions by Dr. S N Rajaguru, Emeritus Scientist, Deccan College, Pune, and Dr. Hema Achyuthan of Anna University, is acknowledged. We are grateful also to the three referees for their critical examination of the manuscript and useful suggestions.

\section{References}

Achyuthan H and Rajaguru S N 1997 Genesis of ferricretes and calcretes of Jayal gravel ridge- a micromorphological approach; Geology in South Asia-II Geological Survey \& Mines Bureau Sri Lanka Professional paper 7 51-59

Achyuthan H and Rajaguru S N 1998 Micromorphology of Quaternary calcrete around Didwana in Thar Desert of Rajasthan; Annals of Arid Zone 37(1) 25-35

Andrews J E, Singhvi A K, Kailath A J, Kuhn R, Dennis P F, Tandon S K and Dhir R P 1998 Do stable isotope data from calcrete record Late Pleistocene monsoonal climate variation in the Thar Desert of India; Quat. Res. $50240-251$

Arakel A V 1982 Genesis of calcrete in Quaternary soil profiles Hutt and Leeman lagoons western Australia; J. Sed. Pet. 52 109-125

Arakel AV and McConchie D 1982 Classification and genesis of calcrete and gypcrete lithofacies in palaeodrainage systems of inland Australia and their relationship to carnotite mineralisation; J. Sed. Pet. 52 1149-1170

Bachman G W and Machette M N 1977 Calcic soils and calcretes in the southwestern United States; U.S. Geol. Survey Open File Report 77-794; 163pp

Chadwick O A and Nettleton W D 1990 Micromorphological evidence of adhesive and cohesive forces in soil concentrations. In: Soil Micromorphology- A Basic and Applied Science (ed) L A Douglas (Amsterdam: Elsevier) 207-212

Chawla S, Dhir R P and Singhvi A K 1992 Thermoluminescence chronology of sand profiles in the Thar Desert and their implications; Quat. Sci. Rev. 11 25-32

Cerling T E and Quade J 1993 Stable carbon and oxygen isotopes in soil carbonates. In : "Continental Isotopic Indicators of Climate" (eds) P. Swartz K.C. Lohmann and J.A. McKenzie AGU Monograph. 78 pp 217-237

Choudhari J S and Dhir R P 1981 Clay mineralogy of medium-fine textured alluvial soils Western Rajasthan; Proc. Indian Natn. Sci. Acad. 47-A (6) 695-704

Choudhari J S and Dhir R P 1982 Clay mineralogy of arid zone soils developed from Quaternary Deposits of Western Rajasthan; Proc. Indian Acad. Sci.(Earth Planet. Sci.) 91(2) 119-126

Courty M A, Dhir R P and Raghavan H 1987 Microfabrics of calcium carbonate accumulations in arid zone soils of Western India. In: Proc. VII Soil Micromorphology Fedoroff et al. (ed) 227-234
Courty M A and Fedoroff N 1985 Micromorphology of recent and buried soils in a semiarid region of northwestern India; Geoderma 35 287-332

Das Sarma D C 1984 Geomorphology of arid zones of Rajasthan and Gujarat; Proc. Indo-US Workshop "Arid Zone Research" Dept of Science and Technology, New Delhi 132-139

Deutz P, Montanez I P, Monger H C and Morrison J 2001 Morphology and isotope heterogeneity of Late Quaternary pedogenic carbonates: implications for Palaeosol carbonates as paleoenvironmental proxies; Paleogeogr. Paleoclimatol., Paleoecol., 166: 393- 317

Dhir R P 1995 Genesis and distribution of arid zone calcretes; Mem. Geol. Soc. India 32 191-209

Dhir R P, Joshi D C and Singh N 1982 Morphology and genesis of calcic layer in soils of arid Rajasthan; $12^{\text {th }}$ Intern. Soil Sci. Congress CommV. Abs 139

Dhir R P and Kolarkar A S 1977 Genesis and evolution of arid zone soils; J Indian Soc Soil Sci. 25 260-284

Dhir R P, Rajaguru S N and Singhvi A K 1994 Desert Quaternary formations and their morphostratigraphy: implications for Quaternary history of the Thar Desert; J. Geol. Soc. India 43(4) 435-447

Ehleringer J R 1988 Carbon isotope ratios and physiological processes in arid grasslands. In "Applications of Stable Isotopic Ratios to Ecological Research" (eds) P W Rundel J R Ehleringer and K.A. Nagy (NY Springer-Verlag) 4154

Eitel B 1995 Contribution to discrimination of Tertiary and Pleistocene Calcretes in Namibia; Regensburg Geog. Schriffen 25 9-21

Eitel B and Stengele F 1996 Kalkkrustenaufbereitung zur Residuumsanalyse: die Anwendung von Salzsaure-und EDTA-Lasungen; Die erde 127 181-191

Ghose B, Singh S and Kar A 1977 Geomorphology of Rajasthan Desert. In: "Desertification and its Control" (ed) P.L. Jaiswal. (New Delhi: ICAR) 69-76

Gile L H, Peterson F F and Grossman R B 1966 Morphological and genetic sequences of carbonate formation in desert soils; Soil Sci. 101 347-360

Goudie A S 1983 Calcrete. In : Chemical Sediments and Geomorphology: Precipitates and Residua in the NearSurface Environment. (eds) A S Goudie and K Pye. 93131 (London: Academic Press)

Jain M, Tandon S K, Bhat S C, Singhvi A K and Mishra S 1999 Alluvial and aeolian sequences along the river Luni, Barmer District: physical stratigraphy and feasibility of luminescence chronology methods; Mem. Geol. Soc. India 42 273-295

Kailath A J, Rao T K G, Dhir R P, Nambi K S N, Gogate V D and Singhvi AK 2000 Electron spin resonance charcterisaton of calcretes from Thar Desert for dating applications; Radiation Measurements 32 371383

Kar A 1992 Geomorphology of Thar Desert in Rajasthan. In "Geomorphological Facets of Rajasthan" (ed) H. Sharma. (Ajmer: Kuldeep Pub) pp 236-264

Kar A, Singhvi A K, Rajaguru S N, Juyal N, Thomas J V, Banerjee D and Dhir R P 2001 Reconstruction of Late Quaternary Environment of the Lower Luni Plains, Thar Desert, India; J. Quaternary Sci. 16(1): 61-68

Khadkikar A S, Merh S S, Malik J N and Chamyal I S 1998 Calcretes in Semi-arid alluvial systems - Formative pathways and sinks; Sed. Geol. 116 251-260

Khadkikar A S, Chamyal L S and Ramesh R 2000 Characterisation and genesis oif calcretes in Late Quaternary alluvial deposits, Gujarat, Western India, and its bearing on the interpretation of ancient climates; Paleogeogr. Paleoclim. Paleoecol. 162 239-261 
Krishna Murthi G S R and Narayan M R 1968 Clay mineralogy of few desert soils of Western Rajasthan; J. Agri. Sci. 38 945-949

Machette M N 1985 Calcic soils of the south western United States. In: Soils and Quaternary Geology of the Southwest United States (ed) D.L. Weide Geol. Soc. Amer. Special Paper No. 203 pp. 1-21

McGrath D B and Hawley J W 1987 Geomorphic evolution and geoimorphic relationship in Socorro area Central New Mexico. In: "Guidebook to the Socorro Area New Mexico". (New Mexico: Bur. of Mines) pp. 55-67

Milnes A R 1992 Calcrete. In: Weathering Soils and Palaeosols (eds) I.P. Martini and W. Chesworth (Amsterdam: Elsevier) pp. 309-345

Misra V N, Rajaguru S N, Raju D R, Raghavan H and Gailard C 1982 Acheulian occupation and evol;ving landscape around Didwana in the Thar Desert, India; Man and Environ 6 72-86

Monger H C and Daugherty L A 1991 Neoformations of palygorskite in a southern New Mexico Aridisol. Soc. Am. J. 55 1646-1650

Nash D J and Smith R F 1998 Multiple calcretes in the Tabernas Basin, Southeast Spain: their origins and geomorphic implications; Earth Surface Process. Landforms 23 1009-1029

Netterberg F. (1969). The interpretation of some basic calcrete types; South African Arch. Bull 24 117-122

Pendall E and Amundson R 1994 Stable isotopic chemistry of pedogenic carbonate in an alluvial soil from the Punjab Pakistan; Soil Sci. 149 199-211

Pimentel N L, Wright V P and Azevdo T M 1996 Distinguishing early groundwater alteration effects from pedogenic in ancient alluvial basins: examples from Palaeogene of Southern Portugal; Sed. Geol. 105 1-10

Quade J, Cerling T E and Bowman J R 1989 Systematic variation in stable carbon and oxygen isotope composition of pedogenic carbonate along elevation transect in southern Great Basin, USA; Geol. Soc. Amer. Bull. 101 464-475

Raghvan H, Courty M A 1987 Holocene and Pleistocene pedo-sedimentary environments in the Thar Desert; Proc. VII Soil Micromorphology Fedoroff et al (Eds) 639-646

Reeves C C 1976. Caliche: Origin Classification and Morphology Land Uses. Estacado Books Lubbock 233 pp.

Sehgal J L and Stoops G 1972 Pedogenic calcite accumulations in arid and semi-arid regions of the Indo-Gangetic alluvial plain of erstwhile Punjab (India); Geoderma 8 $59-72$

Sharma N 1999 Petrography, geochemistry and chronological studies of a calcareous duricrust (Quaternary) of Anwana (Jodhpur District), Rajasthan, India, M.Sc. Thesis Dept. of Geology, University of Delhi

Sidhu P S 1977 Aeolian additions to soils of northwest India; Pedologie 3 323-336

Singer A, Kirsten, W and Buhmann C 1995 Fibrous clay minerals in soils of Namaqualand, South Africa: characteristics and formation; Geoderma 66 43-70
Slate J L, Smith G A, Wang Y and Cerling T E 1996 Carbonate-Palaeosol genesis in the Plio-Pleistocene St. David Formation Southeastern Arizona; J. Sed. Res. 66 85-94

Solomons W, Goudie A and Mook W G 1978 Isotopic composition of calcrete deposits from Europe, Africa and India; Earth Surface Processes 3 43-57

Sundaram R M, Rakshit P and Pareek S 1996 Regional stratigraphy of Quaternary deposits in parts of Thar Desert Rajsthan; J. Geol. Soc. India 48(2) 203-210

Tandon S K, Sareen B K, Rao M S and Singhvi A K 1997 Aggradation history and luminescence chronology of Late Quaternary semiarid sequences of the Sabarmati basin, Gujarat, western India; Paleogeogr. Paleoclim. Paleoecol. 128 339-357

Tandon S K, Andrews J E, Sood A and Mittal S 1998 Shrinkage and sediment supply control on multiple calcrete profile development: a case study from the Maastrichtian of Central India; Sedimentary Geology 119 2545

Tandon S K and Kumar S 1999 Semi-arid/arid zone calcretes: A review. in "Paleoenvironmental Reconstruction of Drylands (ed). A.K. Singhvi and E. Derbyshire. (New Delhi: Oxford-IBH Pub. house) 109-152

Thomas J V, Kar A, Kailath A J, Juyal N, Rajaguru S N and Singhvi A K 1999 Late Pleistocene history of aeolian accumulations in Thar Desert, India; Z. Geomorph. Suppl Bd 116 181-194

Thompson L G, Yao T, Davis M E, Handerson K A, Moseley-Thompson E, Lin N, Beer J, Synai H A, ColeDai J and Bolzan J F 1997 Tropical climate instability: the last glacial cycle from Qinghai_- Tibetan ice core; $S c i$ ence 226 1821-1825

Wang Y, Nahon D and Merino E 1994 Dynamic model of genesis of calcretes replacing silicate rocks in semi-arid regions; Geochim. et Cosmochim. 58 5131-5145

Watts N L 1980 Quaternary pedogenic calcrete from the Kalahari (South Africa): Mineralogy genesis and diagenesis; Sedimentology 27 661-686

Weaver C E and Beck K C 1977 Miocene of the SE united States: model for chemical sediments in a peri-marine environment; Sed. Geol. 17 1-234

Wieder M and Yaalon D 1974 Effect of matrix composition on carbonate nodule crystallisation; Geoderma 1195 121

Wright V P and Tucker M E 1991 Calcretes: an introduction; In: Calcrete Internat. Assoc; Sedimentologists Reprint Series 2 1-22

Yaalon D H 1988 Calcic horizon and calcrete in aridic soils and paleosols: progress in last twenty years; Soil Sci. Soc. Amer. Agron. Abstracts

Yaalon D H and Wieder M 1976. Pedogenic palygorskite in some arid brown soils of Israel; Clay Miner 1173 80

Yadava M G and Ramesh R 1999 Speleothems-useful proxies for paleomonsoon rainfall records; J. Scientific and Industrial Research 58 339-348 